الحماية القانونية لاختراعات التكنولوجيا الحيوية (در اسة تحليلية)

اعداد

د/عبدالرحيم عنتر عبد الرحمن ماضي

•دكتوراه القانون التجاري -ج المنوفية

$$
\text { • دكتوراه القمد محمد عبيل مبارك التجارى- جيوط }
$$

العدد الثاني ( الجزء الثاني)

$$
r+1 V
$$


د / عبدالرحيم عنتر عبدالرحن - د/ محمد محد عبيد مبارك

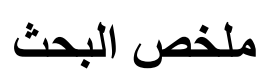

الحماية القانونية لاختراعات التكنولوجيا الحيوية لئة

"دراسة تحليلية

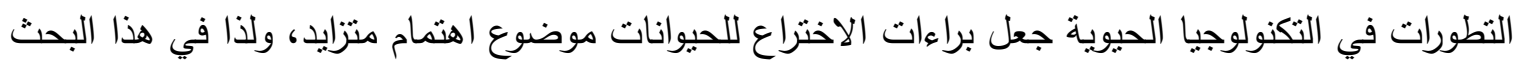

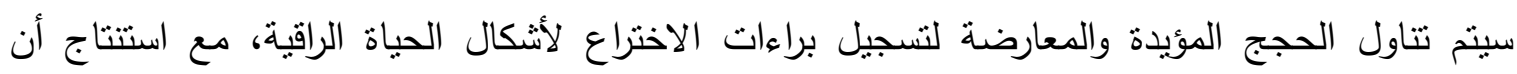

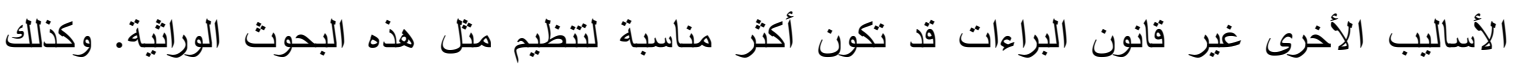

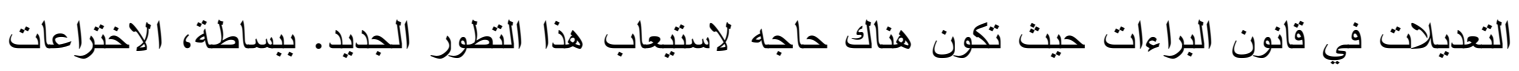

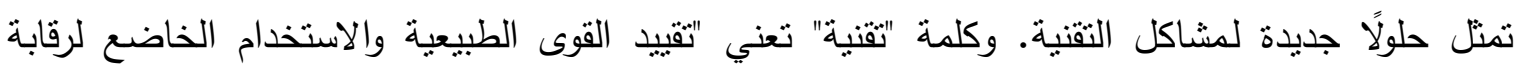
الظواهر الطبيعية هذا هو "النشاط البشري في مجال الظواهر المادية الني تتميز بالفضاء والوقت والمادة

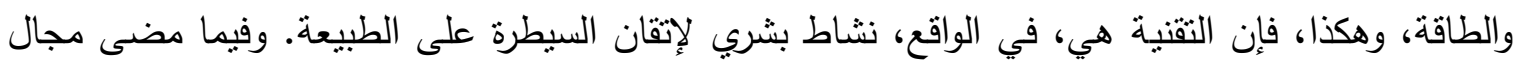

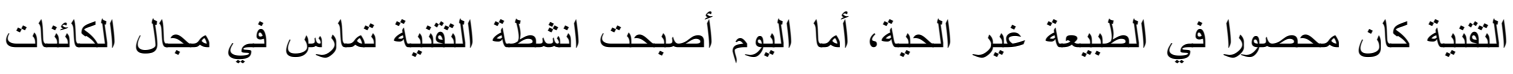

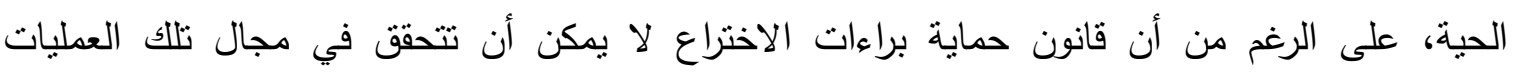

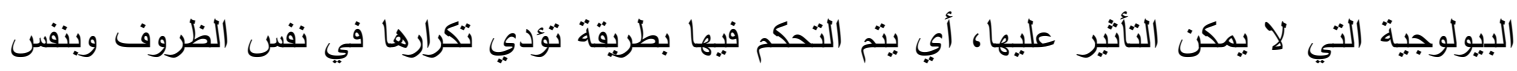
النتائج.

\section{Legal protection of biotechnological inventions}

\section{"Study Analysis"}

Advances the domain of technique was confined to nonliving nature. Yet, today, it has been considered that technique also comprises the activities in the field of living beings, although the patent law protection cannot be realized in biotechnology have made the patenting of animals a subject of increased interest.. This article surveys the arguments for and against patenting higher life forms, concluding that methods other than patent law may be more appropriate for regulating such genetic research. Simply saying, inventions represent new solutions to technical problems. The word "technique" means "restraining of natural forces and controlled use of natural phenomena", that is "human activity in the field of material phenomena characterized by space, time, matter and energy" . Thus, the technique is, actually, human activity to master and control nature. Once in domain of those biological processes which cannot be influenced, that is, controlled in a way that their repetition under same conditions would yield the same results. 


\section{المقدمة}

إن المعرفة والتقدم التقني مستمر حتى أصبح يطلق على هذا القرن قرن الثورة العلمية( ()، بالرغم من

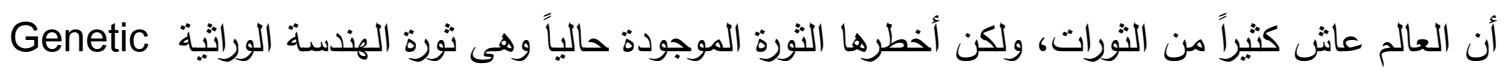
(Engineering) المعلومات الوراثية (Genetic Information) والتي ترتبط بتكوين الجنين، وسير العمليات الحيوية داخله،

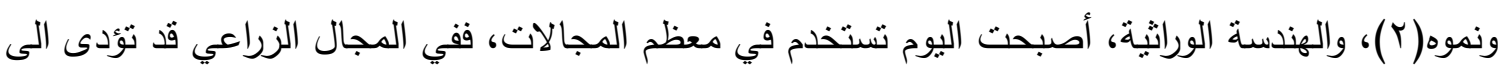

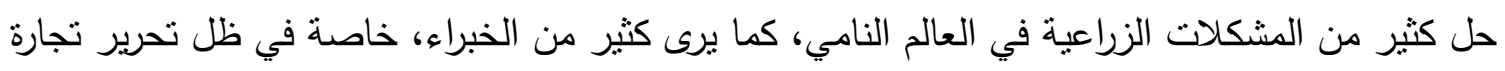

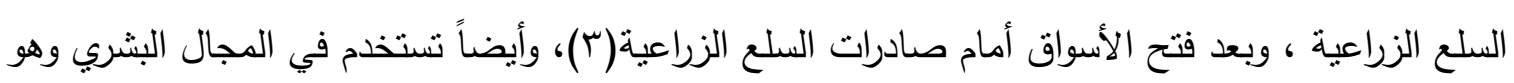

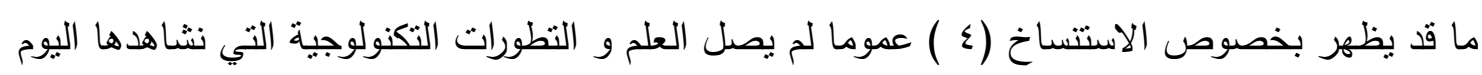

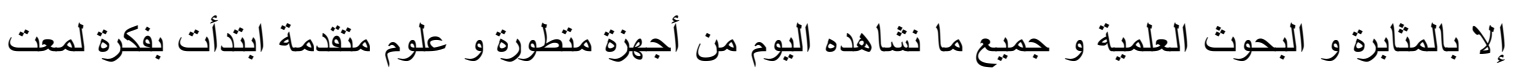

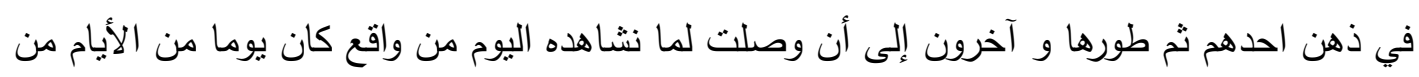

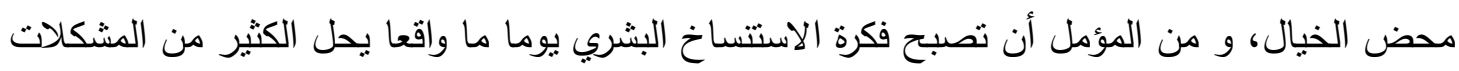
العالقة التي لم يتوصل الطب إلى حلها.

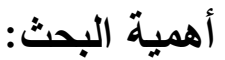

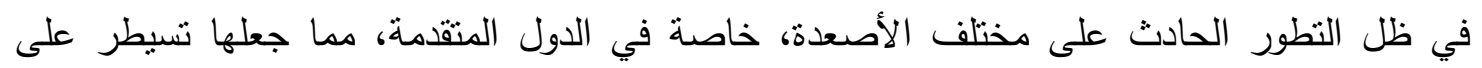

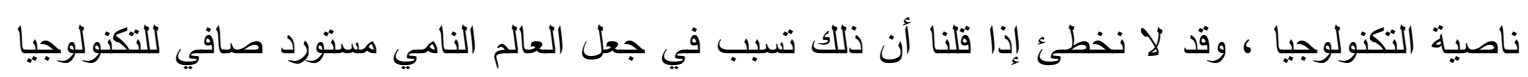

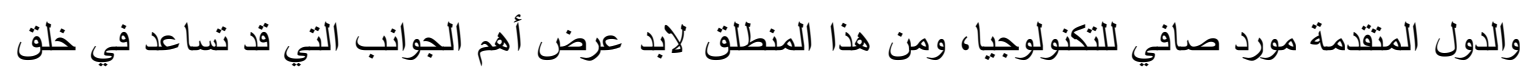

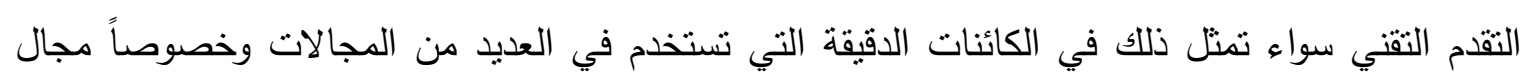

(1) يجب ملاحظة أن مصطلح الهندسة الوراثية هو المصطلح الأكثر شيوعاً لمجموعة الأساليب التقنية المستخدمة في مجال

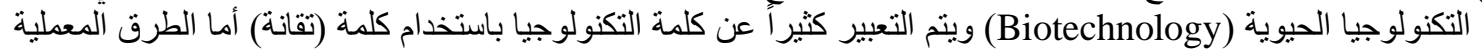

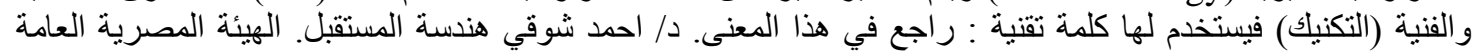

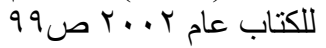

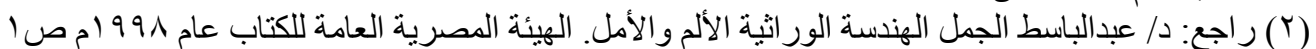

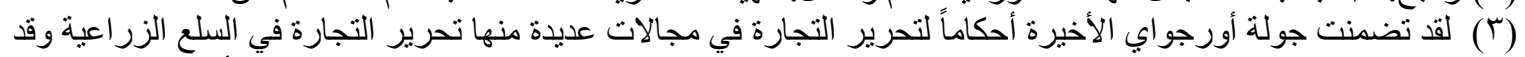

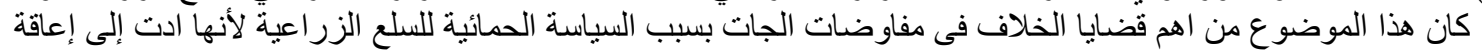

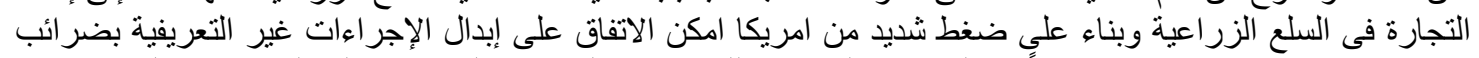

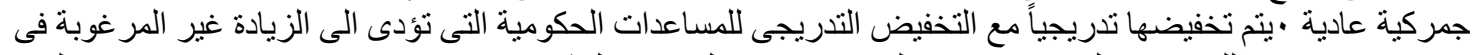

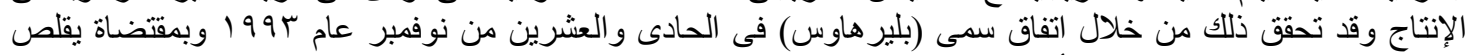

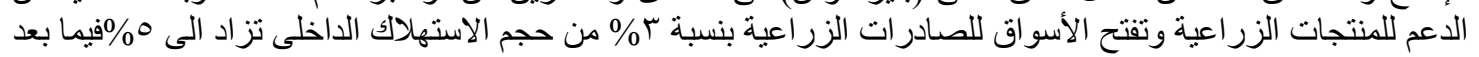

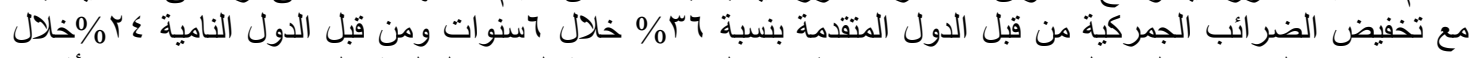

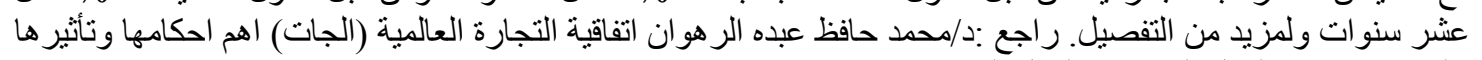

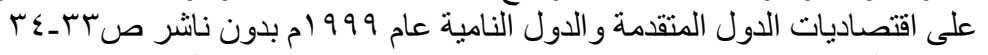

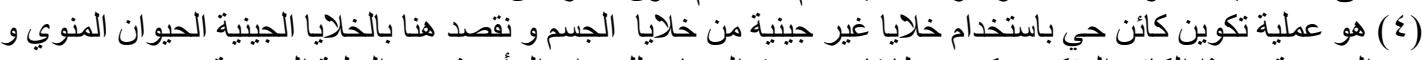

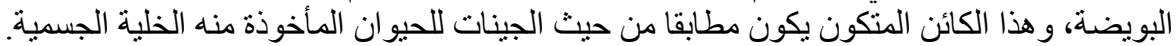
http://www.fiqhacademy.org.sa/qrarat/l·-r.htm 
الدواء أيضا نوضيح دور التكنولوجيا الحيوية خاصة وأنها أصبحت العمود الفقري تقريبا لكل تطور تقني على مختلف الأصعدة، مما بساعد في رسم سياسة العالم النامي بخصوص التكنية التكولوجيا الحيوية.

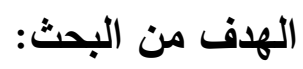
- - إبراز أهمية التكنولوجية الحيوية لدفع العالم النامي ملاحقة ركب النقام التقني. - بيان مدى إمكانية حماية الاختراعات الناتجة عن التكنولوجيا الحيوية كحقوق فكرية - - توضح موقف كل من العالم النامي والعالم المنقدم من بعض اختراعات التكنولوجيا الحيوية. مشكلة البحث:

من المستقر عليه أنه: أن حقوق الملكية الفكرية بشقيها، الملكية الصناعية، والملكية الأدبية والفنية، يتم

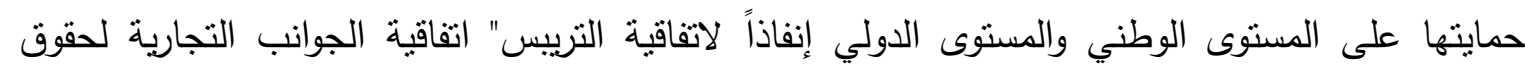
الملكية، ولكن حماية الاختراعات الناتجة عن التكنولوجيا الحيوية، قد يثير إثكالية فكيف يتم حماية

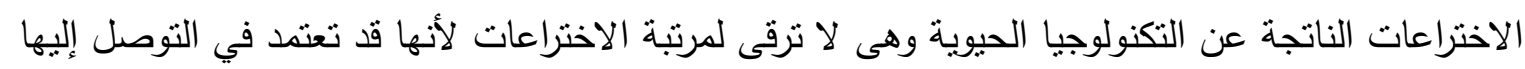

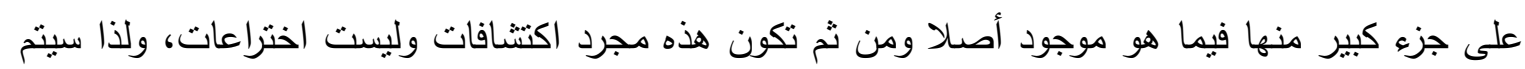
من خلال هذا البحث طرح التساؤلات التالية:

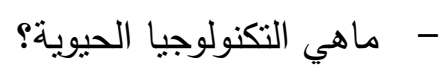

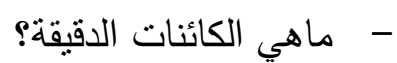
- - هل الكائنات الدقيقة تعد اختراعات ام مجرد اكتثافات؟

- مدى إمكانية حماية الاختراعات الناتجة عن التكنولوجيا الحيوية كحقوق فكرية؟

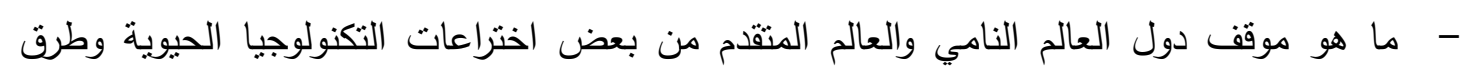
حمايتها! وسوف نقصر هذه الدراسـة بإلقاء الضوء على الكائنات الدقيقة مـع التفصيل بثـان التكنولوجيا الحيوية وطرق حمايتها قانونيا.

ولذا سيتم تقسيم هذا البحث إلى مبحثين على النحو التالي: ولاني المبحث الاول :ماهية التكنولوجيا الحيوية والتطور التاريخي للكائنات الدقيقة التئة التئي المطلب الاول: ماهية التكنولوجيا الحيوية. المطلب الثاني : التطور التاريخي للتعريف بالكائنات الدقيقة.

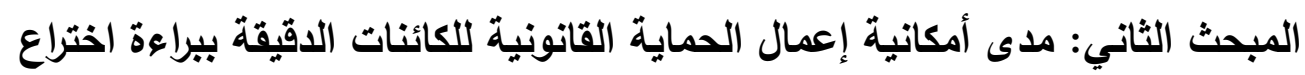

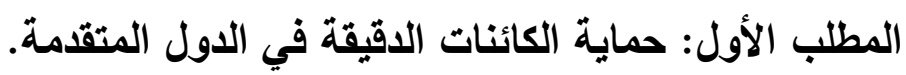
المطلب الثاني: حماية الكائنات الاقيقة في الدول النامية. 


\section{المبحث الاول}

\section{ماهية التكنولوجيا الحيوية والتطور التاريخي للكائنات الدقيقة}

تباينت الحماية القانونية للتكنولوجيا الحيوية وذلك باختلاف الانظمة والتشريعات التي قررت لها هذه

الحماية ،حيث أن بعض من هذه الحماية مقرر باتفاقيات دولية نم التوقيع عليها من قبل الامم المتحدة ، والبعض الاخر جاء في القوانين والتشريعات الوطنية الخاصة بالدول والتي قررت حماية التكنولوجيا الحيوية.

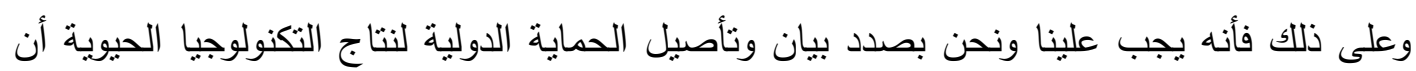

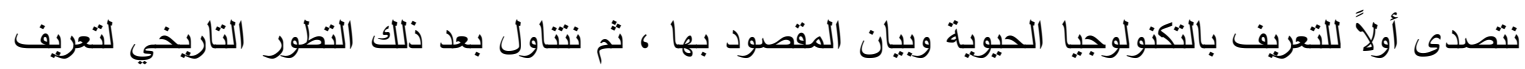
الكائنات الدقيقة ، وذللك بأن نخصص لكل منهم مطلب مسنقل على النحو التالي :

\section{المطلب الأول}

\section{ماهية التكنولوجيا الحيوية}

التكنولوجيا الحيوية لها العديد من التعريفات المتباينة وإن كان معظمها يدور حول معنى واحد فقد تم

تعريفها بانها التطبيقات الحيوية والأنظمة ومراحل الإنتاج التصنيعيةهوبأنها ثقنية تستخدم الظواهر الحيان الحيوية لنسخ وإنتاج منتجات حيوية مفيدة.وأيضاً تم تعريفها من قبل الولايات المتحدة الأمريكية بأنها هي استخدام منظم للأحياء مثل الأحياء الدقيقة وزراعة الأنسجة أو أجزاء منها (1).

وعلية فأنه يمكننا تعريف التقنية الحيوية على أنها: "هي الاستخدام المنظم للظواهر الحيوية من أجل تطبيقها صناعياً"

ومن الجدير بالذكر أن التكنولوجيا الحيوية تعتمد على الموارد الوراثية التي هي عبارة عن الأصل الوراثي النباتي والحيواني أو الكائنات الدقيقة النادرة والمعارف التقليدية والممارسات المحلية التي تحيط بهاته والتي تراكمت عبر السنين، وعبر أجيال متلاحقة لتصبح سمة مميزة لمجتمع ما، ومن هنا كان اكتشاف المادة الوراثية أو الحمض النووي الدنا (DNA)، من العوامل الدافعة أيضاً لتطور مفهوم التقنية الحيوية، (ז).

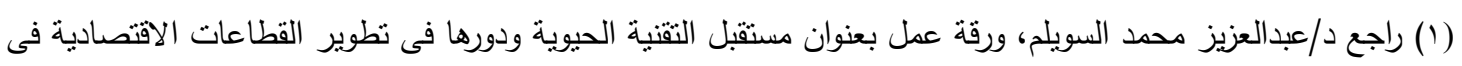

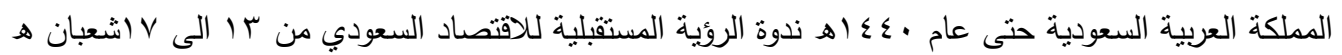
r-r(ص)

(retroviruses) من هذه الأساليب استخدام انواع معينة من الفيروسات (res) وهارة عن فيروسات تعمل على تحويل

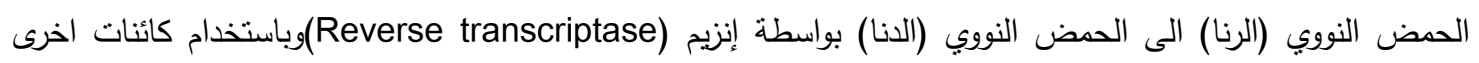
تسمى (Retrotransposons) واستخدام (liposomes) اللييوسومات وهى عبارة عن جسيمات مفرغة أو استخدام خلايا

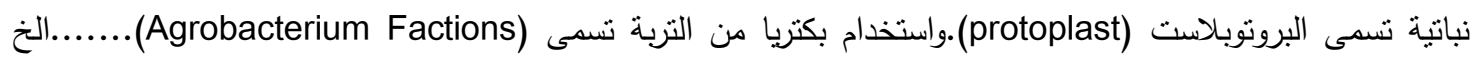

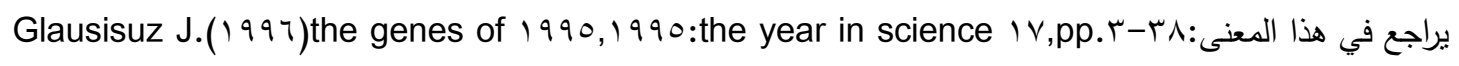


د/ عبدالرحيم عنتر عبدالرحن - د/ محمد محمد عبيد مبارك

ولقد حبى الله العالم النامي بالكثير من الثروات ولذا قد لا نخطئ إذا قلنا إن الموارد الوراثية تعد بمثابة

العمود الفقري للدول النامية، بمعنى انه توجد المادة لخام للعالم النامي مما يعطيه الكثير من نقاط التميز عندا لـال

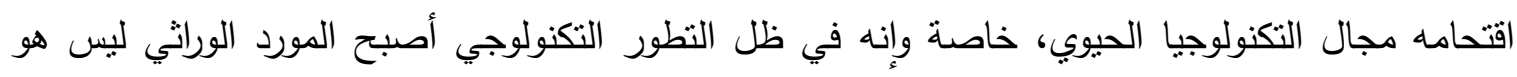
الكائن الكامل أو العضو أو الخلية ولكن الصفة أو الميزة أو التركيبة الجينية، والتي تتميز بخصائص فسيولوجية نادرة ويمكن أن تنتقل من كائن إلى آخر، بمعنى أن التحوير الوراتي كان في السابق تحويراً ضمن نفس النوع أو الجنس، وأحياناً من خلايا التزاوج والتلقيح، أما الآن فالتحوير الوراثي يحدث بنثي بنقل الجينات من نوع إلى آخر أو بتحوير جينات من نفس النوع، ويصبح عندها الكائن الذي تم تغيير سلسلته

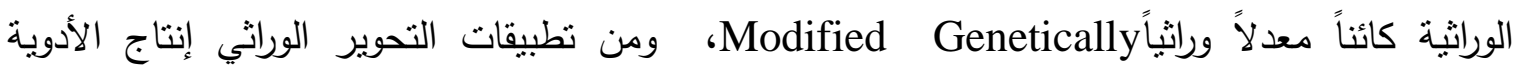
واللقاحات وعلاج بعض الأمراض الجينية وزيادة الإنتاج الزراعي وتقليل التكلفة وزيادة المحتوى الغذائي في (1) (1) (1)

(1) و هكذا ترى للهنسة الور اثية فو ائد كثيرة خاصة بعد معرفة العلماء بكيفية عمل الجينات وذلك عن طريق استبدال الجينات

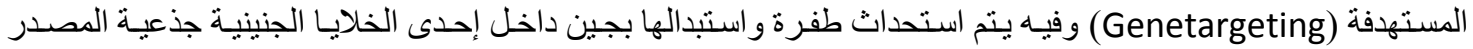

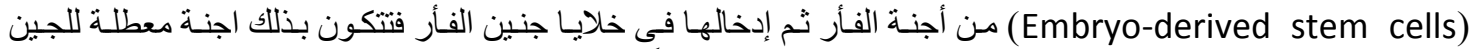

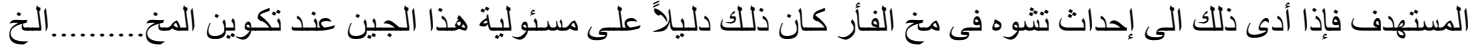

I-http://www.smsec.com/family/sc 2 all/geeng ${ }^{\vee}$.htm ولمزيد من التفصيل راجع المو اقع التالية على شبكة الانترنت:

r- http://www.werathah.com/learning/papers/concergenetics.doc

r- http://www.fao.org/ag/magazine/fao-org.pdf 
ولذا الأمر بالنسبة للدول النامية في ظل هذه التطورات المتلاحقة خاصة وأنها تملك الكثبر من الموارد الوراثية المتنوعة ذات القيمة العالية يحتم عليها مواجهة هذه التحديات في إطار الفهر الجيد للاتفاقيات الدولية، ووضع الحلول المناسبة على نحو يساعد على المحافظة على الموارد الوراثية وحسن استخلالها من خلا التشريعات الوطنية بما ينعكس بالخير والنماء عليها، وقد تم اقتراح استراتيجية التتمية المستدامة التي تهدف إلى الاستخدام الأمنل للموارد الوراثية والمحافظة على تتوعه (Sustainable Development) البيولوجي، وتطوير أساليب جديدة للمادة الحية(التطوير الوراثي) باستخدام أدوات التكنولوجيا الحيوية.(')

\section{ولقد أوضحت ذلك اتفاقية التنوع البيولوجي، ومن الجدير بالذكر أن هذه الاتفاقية هي معاهدة دولية}

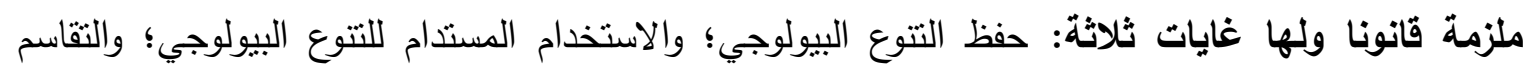
العادل والمنصف للمنافع الناشئة عن استخدام الموارد الجينية. ويتمنت هدفها العام في تشجيع الأعمال التي تقود إلى مستقبل مستدام.وقد صنفت بعض من تللك الأدوات والأساليب، خاصة ما يقع تحت ما يسمى بالمعارف الفنية (Know-How) (؟)، على أنها ملك من قام بتطويرها، ومن هنا تم اقتراح حماية هذه التكنولوجيا بحقوق الملكية الفكرية، ويعد مكمن الخطر هنا أن الدول النامية خاصة التي تعثبر منشأ للموارد

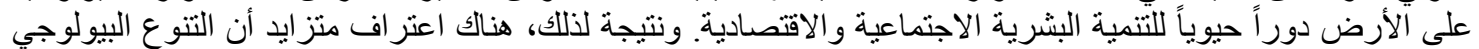

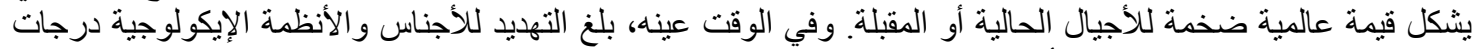

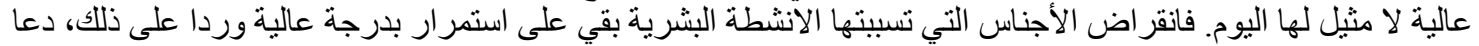

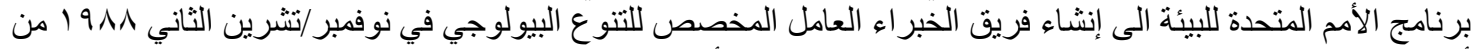

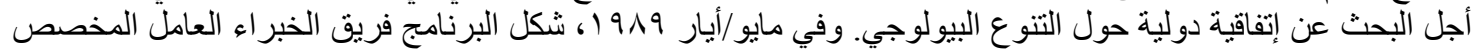

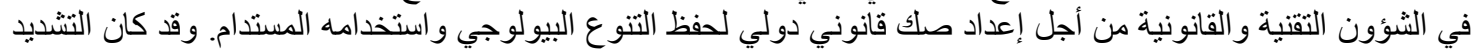

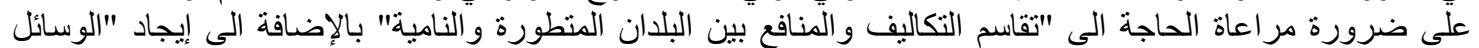

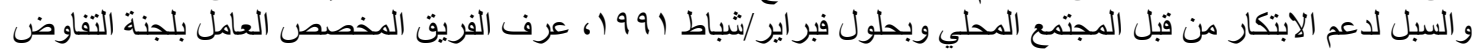

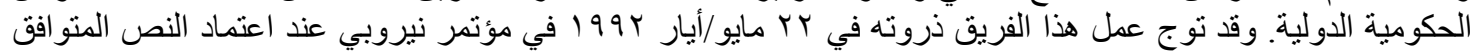

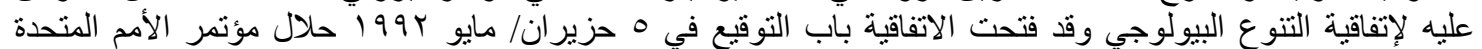

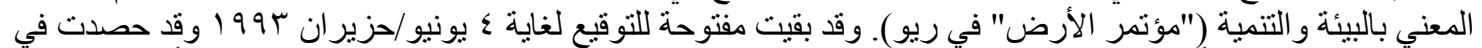

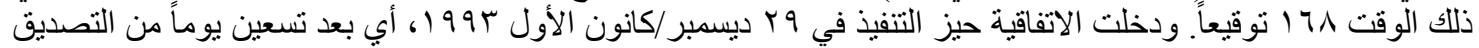

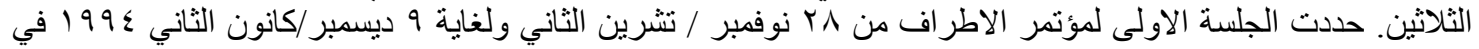

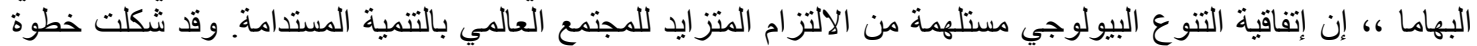

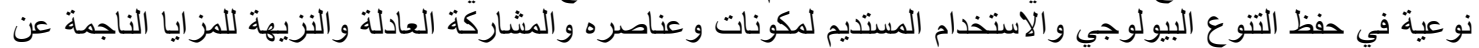

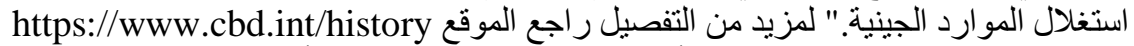

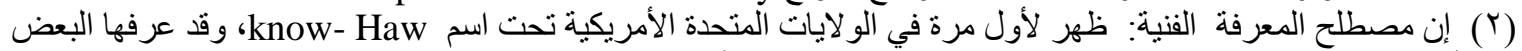

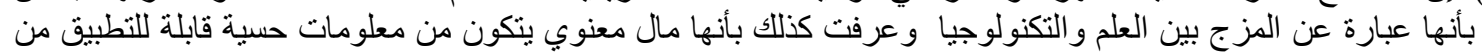

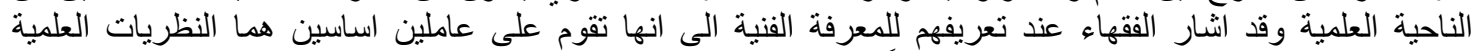

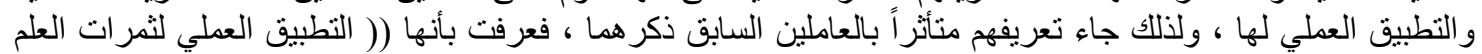

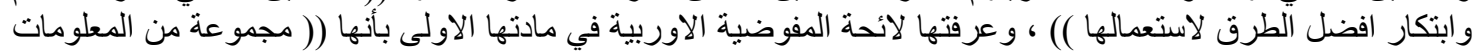

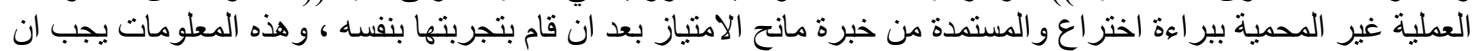
تكون سرية وجدية ولها ذاتية خاصة )) .ولمزيد من التفصيل راجع د. دالئ عادل شمر ان الثمري، كلية القانون جامعة كربلاء،

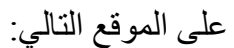

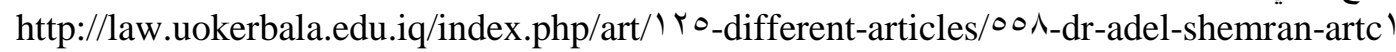


الوراثية لا تملك القدر الكافي من التكنولوجيا الحديثة والموارد المالية، التي تمكنها من تطوير مواردها الوراثية

وحمايتها بالرغم من أن اتفاقية التتوع البيولوجي أقرت حق الدولة وسيادتها على مواردها الوراثية. (()

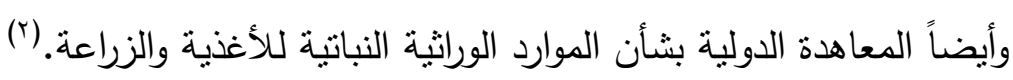

International Treaty on Plan ( Genetic Resources For Food and Agriculture

اعترفت بحقوق الملكيـة الفكريـة للمجتمعات والجماعات المحلية وللدول التي تملك الموارد الوراثيـة للأغذيـة والزراعة، ورغم ذللك تم تتقيح اتفاقية اليوبوف UPOV عام او9 ام على نحو قلص حرية الدول النامية، كمـا ظهر مـا بســى بالقرصـنة الحيويـة (Bio-piracy) وذلك بالسـطو على الثروات البيولوجيـة للـدول

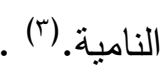

( (1) راجع (المادة9) من المعاهدة الدولية بثأن الموارد الوراثية النباتية للأغذية والزراعة (الجزء الثالث)

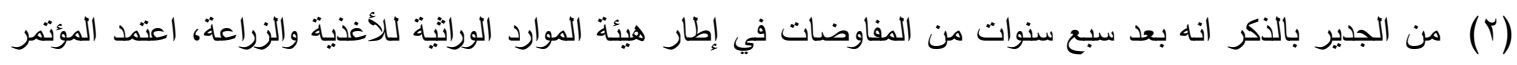

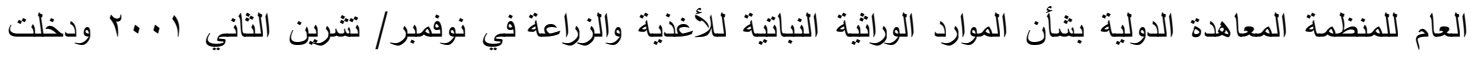

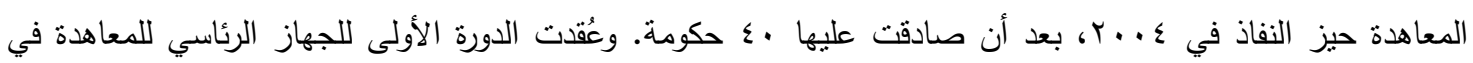

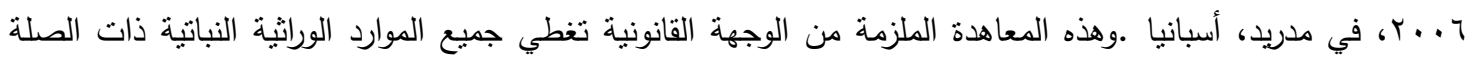

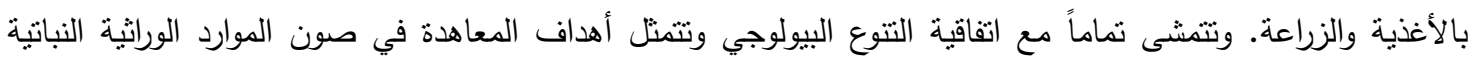

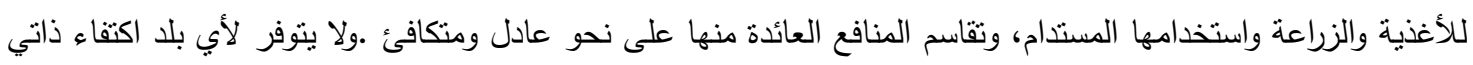

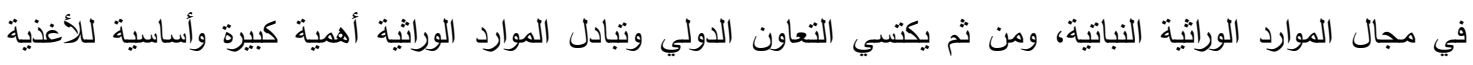
والزراعة. ووافقت البلدان من خلال المعاهدة على إنثاء نظام متعدد الأطراف لنسهيل النفاذ إلى الموارد الوراثية النباتية

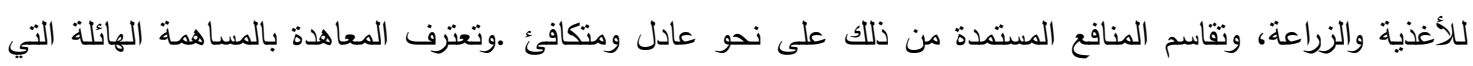

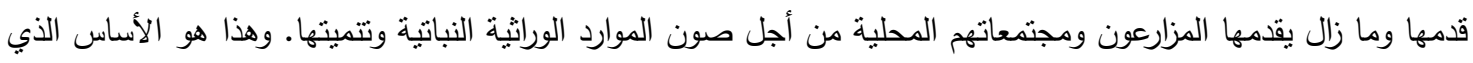
ترتكز عليه حقوق المزارعين، التي تشمل حماية المعرفة التقليدية وحق المشاركة على نحو منكافئ في نقاسم المنافع وفي

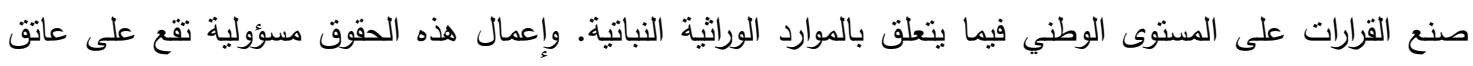

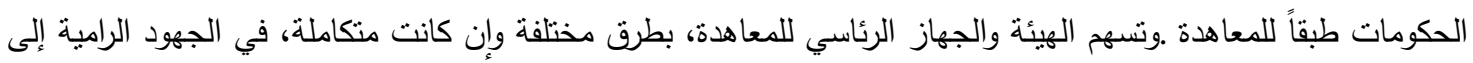

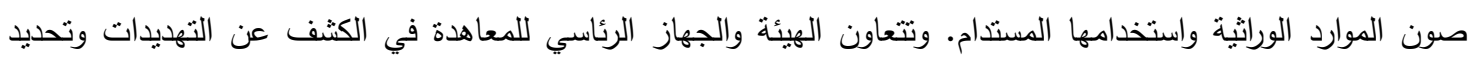

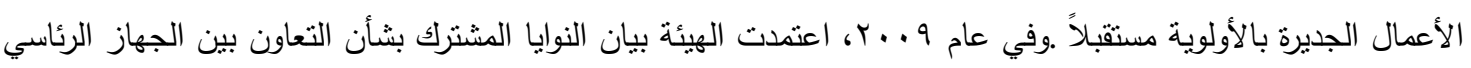

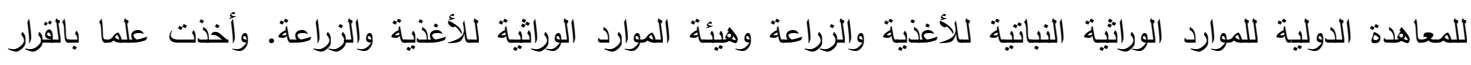

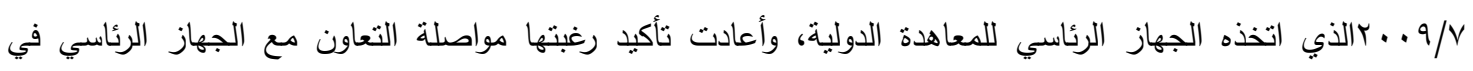

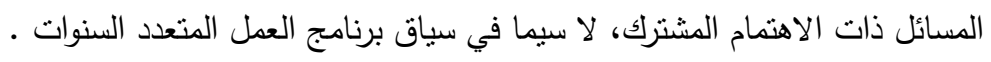
ولمزيد من المعلومات راجع الموقع التالي على شبكة الانترنت: http://www.fao.org/nr/cgrfa/cgrfa-global/cgrfa-planttr/ar/

$$
\text { (ץ) لمزيد من التفصل عن اتفاقية اليوبوف رجع الموقع النالي على شبكة الانترنت: }
$$
http://www.upov.int/en/publications/conventions//99)/act) (99).htm 


\section{المطلب الثاني}

\section{التطور التاريخي لتعريف الكائنات الاقيقة}

الكائنات الاقيقة يقصد بها : " الأحياء المجهرية التي لا يمكن أن ترى بالعين المجردة، ولكن تحت مجهر خفيف عادى، لأنها صغيرة جداً إذ يبلغ حجمها أقل من الميكرون(') Un micron(أو عشرات الميكرونات في الأبعد الخطية (Tens of Micron in Leaner Dimension)

ومن الجدير بالملاحظة أن هذا التعريف شائعاً بمعنى أنه لا يمكن من خلاله القول بأن هذا التعريف

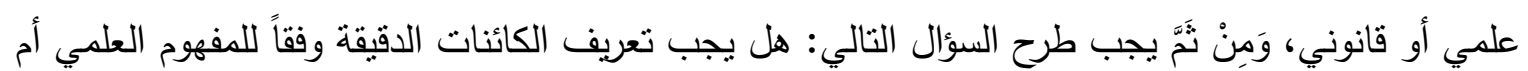
وفقاً للمفهوم القانوني، أح وفقاً للغة السوق،وإن كنا في محل دراسة القانون إلا أننا نرى أن بيان المفهوم العلمي ذو أهمية خاصة حتى نستطيع أن نصل إلى التعريف الذي لا يتعارض مع اتفاقية التربس. التعريف العلمي للكائنات الاقيقة : حتى القرن الماضي صنفت الكائنات الحية إلى نباتات، وحيوانات مع وضوح اختلافها في الثكل والتركيب واختلافها في أنماط التغذية. (؟)

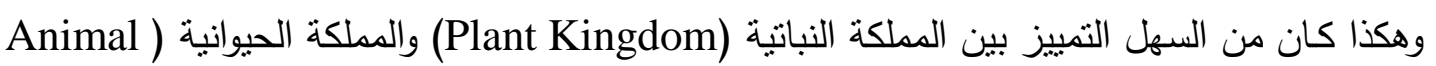
(Kingdom وكان يوجد القليل من المعرفة عن الكائنات الدقيقة، لدرجة أن الفطر (Fungi) كان ينت النظر إلية على أن وضعه مع النباتات الراقية أكثر ملائمة؛ ولذا تم ضمه الى المملكة النباتية بالرغم من أنه عموماً غير ذاتي التغذية (Heterotrophic Nutrition)(־)، ورغم ذللك كان القرار أكثر صعوبة بالنسبة للبكنتيريا (Bacteria) والكائنات وحيدة الخلية (Unicellular Organisms) إلى أي من المملكتين ينضما؛ ولذا ظهر التقسيم الثالث للكائنات الحية (Living Organisms) والتي يجمعها اسم (Protest)، (\&) وهذه المملكة تتضمن الكائنات المختلفة عن مملكة النبات ومملكة الحيوان،(0) ومعظم أفراد هذه المملكة تكون وحيدة الخلية، وقد قسمت هذه المملكة فيما بعد

(') Chavanne et Burst droit de la properiété industrielle edition 199. no. 11^ p.1.4

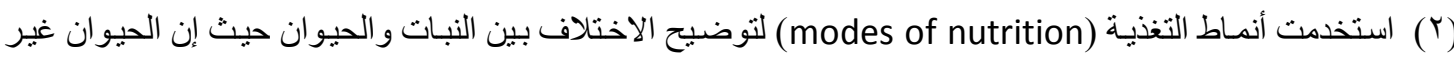

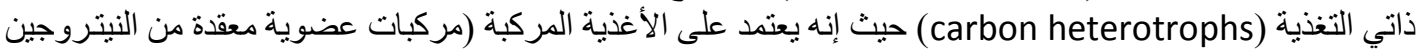

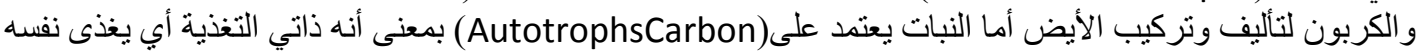

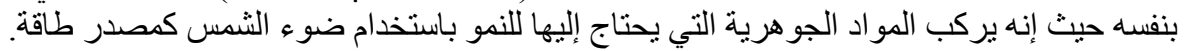

( $\left.{ }^{r}\right)$ - Heterotrophic nutrition is nutrition obtained by digesting organic compounds prepared by other plants or animal tissues. All animals and non-green plants cannot make their own food; hence they depend on others directly or indirectly for their food supply. They are called heterotrophs. They break down the complex compounds into simpler forms. Simply put, heterotrophs have to depend on other sources for their survival. They lack chlorophyll and thus cannot perform photosynthesis. Essentially heterotrophic mode of nutrition is further subdivided into three groups called as: Holozoic, Saprophytic and Parasitic nutrition. A brief description of these divisions is mentioned below more information see, http://www.stylecraze.com/articles/heterotrophic-nutrition-and-what-are-its-types/

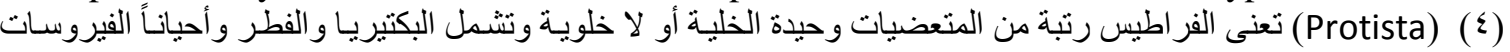

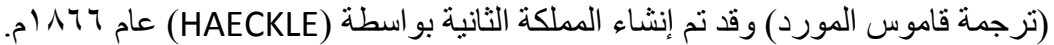

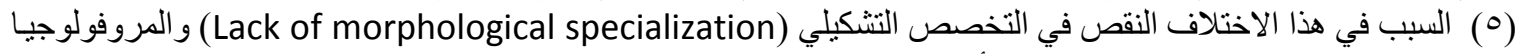
(morphologic) 
د/ عبدالرحيم عنتر عبدالرحمن - د/ محمد محمد عبيد مبارك

إلى مجموعتين مختلفتين على أساس التركيب الخلوي):Cellular Structure) المجموعة الأولى: (Higher Protests) مثل النباتات والحيوانات في تركيبها الخلوي وتسمى(Eukaryotes) (')وهذه المجموعة تتضمن الطحالب (Algae) والفطريات، والـ (Protozoa).

المجموعة الثانية: (LowerProtests) والتي تتضمن البكتيريا وCyanbacteria) وتسمى(Prokaryotes)حيث إن تركيبها الخلوي شديد الاختلاف عن كل الكائنات الأخرى.

ولكن التطورات اللاحقة في دراسة الكائنات الدقيقة أنثتت أن هذا التميز غير كاف لكل الكائنات الدقيقة التي يتم اكتثافها؛ لذا ظهرت مملكة إلفقراطيس وأصبحت قاصرة على أثكال الحياة التي تتمنل في Kingdom ) بينما (Eukaryotic Microbial) (r) (Moneta بل أكثر من ذللك في دراسة حديثة تم تقسيم الكائنات الحية إلى ست ممالك، حيث إن Eubacteria ) تحيط بكل من مملكة، ولكن قيل إن مملكة (Moneta) تهونه (Archaebacterial) Archaebacterial )، ولتحديد خصائص الكائنات الدقيقة قيل إنها كائنات لا ترى بالعين المجردة ولكن ترى لهن تحت مجهر خفيف عادى، بمعنى أنها كائنات صغيرة جداً؛ ولذا نم وصفها من قبل العلماء بأنها كائنات دقيقة من حيث الحجم، وقيل، أيضاً، إنه تم تصنيف الكائنات الدقيقة، وفقاً لعدة عناصر وهى وهى التكوين

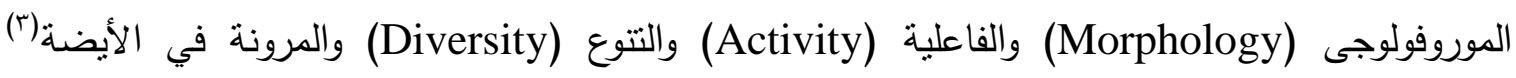
(Flexibility Of Metabolism) الكائنات الدقيقة يتضمن كائنات مختلفة جداً من شكل إلى آخر من حيث دورة الحياة ونمط المعيشة؛ وهذا يعنى أنه لا يوجد تعريف موحد للكائنات الدقيقة ولذا تم تعريف مصطلح الكائنات الدقيقة بتعريفات عديدة ويمكن ذكر بعض منها على النحو التالى:

(1) Every living organism can be categorized as either a prokaryote or a eukaryote. There are many different examples of both types of organisms.Learn about prokaryotes and eukaryotes, Definition of eukaryotes and prokaryotes Prokaryotes (pro-KAR-ee-ot-es) (from Old Greek pro- before + karyon nut or kernel, referring to the cell nucleus, + suffix -otos, pl. -otes; also spelled "procaryotes") are organisms without a cell nucleus (= karyon), or any other membrane-bound organelles. Most are unicellular, but some prokaryotes are multicellular. Eukaryotes (IPA: [ju: 'kæ..Int]) are organisms whose cells are organized into complex structures by internal membranes and a cytoskeleton. The most characteristic membrane bound structure is the nucleus. This feature gives them their name, (also spelled "eucaryote,") which comes from the Greek $\varepsilon v$, meaning good/true, and Kápvov, meaning nut, referring to the nucleus. Animals, plants, fungi, and protists are eukaryotes.

http://www.diffen.com/difference/Eukaryotic_Cell_vs_Prokaryotic_Cell

$(\uparrow)$ The monera,new Latin meaning non-nucleated protoplasmic

أي إن كلمة monera هى معنى لاتينى المقصود به عديمة النواة البروتو بلازمية (الدر اسات الأخرى لنظرية التطور

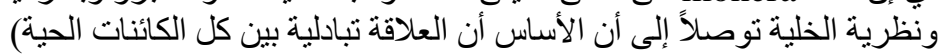

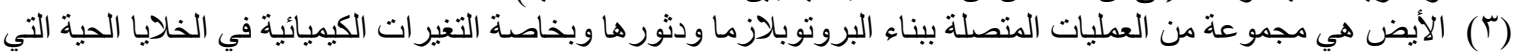
تؤمن بها الطاقة الضرورية للعمليات و النشاطات الحيوية والتي بها تمثل المو اد الجديدة لتعويض التئرات المندثر منها 
Protozoalالـ أى من الكائنات الفيروسية المجهرية التي تتضمن الطحالب، البكتيريا، الفطر والفيروسات (').

r- الكائنات الدقيقة هي: الكائنات التي يمكن رؤيتها فقط تحت مجهر خفيف عادى، حيث إنها تمثل عشرات من الميكرونات في الأبعاد الخطية (جزء من المليون بالأميتر)، (؟).

وتتضمن البكتيريا، الـ Mycoplasma والخمائر Yeasts والطحالب وحيدة الخلية ( - Single

Multicellular و والـ Pelled Algae (Organism يصنفونها ككائنات، حيث إنهم يعتمدون على تكاثر الخلايا (r).

ولذا يجب ملاحظة أن ( الفيروسات لا تعتبر حية، حيث إنها غير قادرة على التكاثز خارج الخلية الحية).

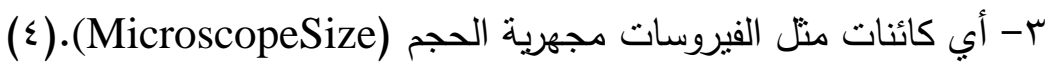

ع - مصطلح الكائنات الدقيقة مشتق من الحجم الدقيق للكائنات الحية المختلفة، ولكنها تتضمن الفيروسات

بالرغم من أن الفيروسات غير خلوية، بمعنى أنها غير قادر على الحياة مستقله (ه).

ه الكائنات المجهريـة تنكون من خلية واحدة، أو خلية عنقودية (Single Cell or Cell Cluster)

كوالفيروسات(؟).

ج- الكائنات الدقيقة تكون أنثكال حياة مجهرية تتضمن، الفطريات المجهرية (Protest) و Prokaryotes)

والفيروسات(v).

V الكائنـات الاقيقة تتكـون مـن: كائنات عديدة مميزة معظم أعضـائها من الأبعاد المجهريـة ورغم تعدد التعريفات السابقة إلا أننا نجد أنه يوجد تعريفان ذو أهمية خاصة للدول النامية وهما

(1)Definition the concise oxford dictionary

( $\Gamma)$ Definition: institute of science UK.

(r) الأميتر وحدة قياس (مثل المتر - السنتيمتر )

(₹) COLLINS ENGLISH DICTIONARY

(0) Micro-organisms function ,form and environment. Hawker and Linton

(7) Biology of micro-organisms. Brock

$(v)$ Introduction to microbiology Heritage Evans and Killington biology of microorganismsHawker, Linton, and Carli

ملحوظة : التعريفات السابقة للكائنات الدقيقة مثار إليها فى المرجع التالى:

DR.Mike Adcock, DR.Margaret ILewelyn.Sheffield Institute for biotechnology law and ethics university of Sheffield UK occasional paper $r$ micro-organisms Divinations and option under TRIPS and micro-organisms. Definition and options under TRIPS: friends whorled committee for consultation Quaker United Nations office Geneva Switzerland.pp. ₹- 9

وقد تستخدم كلمة ميكروب (microbes) بدلاً من الكائنات الدقيقة عند بعض العلماء ولمزيد من المعلومات طالع الموقع التالي على شبكة النت

http://www.le.ac.uk/se/centers/sci/selfstudy/ecov.htm

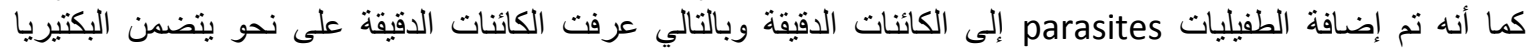
و الفطريات و الطحالب و الطفيليات و الفيروسات لمزيد من التفصيل طالع المرجع السابق مباتشرة 
التعريف الأول: الكائنـات الدقيقة: يقصد بها الأحياء المجهرية، التي لا يمكن أن ترى بالعين المجردة ولكن تحت المجهر، لأنها صغيرة جدا إذ يبلغ حجمها أقل من ميكرون (Un micron) وتشمل البكتيريا، والفطريات، والطحالب، والكائنات وحيدة الخلية (Protozoa) والفيروسات (1).

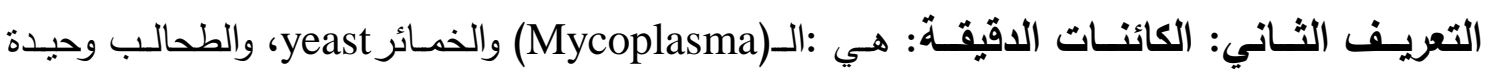
الخلية(single-celled algae)،الـ (Protozoa) وهى لا تشمل الكائنات متعددة الخلية ولا الطحالب التي هـي جزء مـن الخمائر ، وأيضـاً الفيروسـات ليست منضـمة تلقائياً حيث إن كثيراً مـن العلمـاء لا يصنفونها ككائنات حيث إن الفيروسات تعتمد على الخلايا في تكاثرها (r). ومن جانبنا نوئيا التعريف الأول: ولكن باستثناء الفيروسات؛ وبالتالي تشمل الكائنات الدقيقة، البكتيريا والفطر والطحالب والكائنات وحيدة الخلية وذلك بمنع تضمين الفيروسات لأنه لا بمكن أن تعيش بمفردها ولكن تعيش فقط على الخلايا الحية وبالتالي لا تستطيع أن تتكاثر بدون هذه الخلايا الحية، وهذا التعريف للكائنات الدقيقة لم يتوسع في تعريفها، وهو ما يخدم مصالح الدول النامية؛ ولذا يجب أن تتمسك بـه الدول

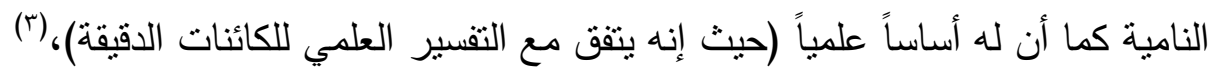
التعريف القانوني: الصعوبة العلمية في تعريف الكائنات الدقيقة تدفعنا إلى البحث عن التعريف القانوني، وهل يوجد تعريف قانوني أم لا ، الحقيقة أن مكاتب براءات الاختراع في الدول المتقدمة مثل أمريكا وأوروبا واليابان لم تهتم بتحديد ما يعد وما لا يعد كائنات دقيقة، السبب في ذلك بسيط وهو أن تعريف مصطلح الكائنات الدقيقة لم تظهر أحكامه داخل تشريعات براءة الاختراع وإن كان قانون البراءة الأوروبي مختلفاً عن القـانون الأمريكي بخصـوص الاكتشـافات (Discoveries)، (؛) والاختراعـات التي تتعـارض مـع الأخـلاق

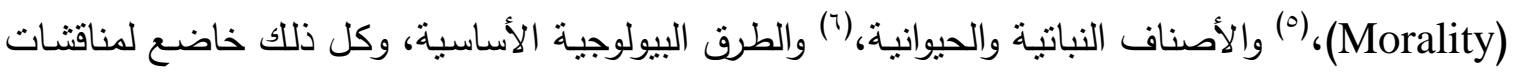
في الهيئة الاستئنافية لمكتب براءة الاختراع الأوروبي ( European Patent Office Board of (Appeal

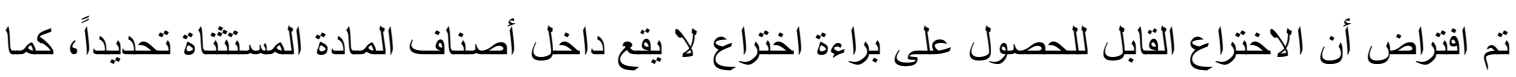

(1) (النهضة راجع/ حسام الدين عبد الغنى الصغير : أسس ومبادئ اتفاقية الجو انب المتعلقة بالتجارة من حقوق الملكية الفكرية دار

$(r)$ DR.Mae-Wan HO and DR. Terje Traovik. why we should reject biotech patent from TRIPS article $r v, r$.(b)p.' available at: http://www.twnsid.org.sg/title/reject-cn.htm

( ${ }^{\top}$ Coombs Macmillan Dictionary of biotechnology ,Macmillan, London 1917 .p. 191

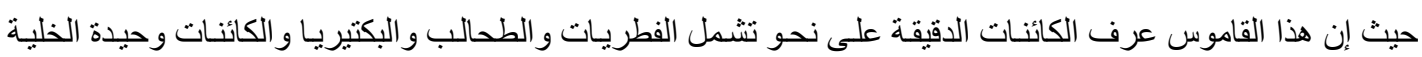
و الفيروسات ولكننا لم نذكر الفيروسات لأنها كما ذكرنا كثير من العلماء لا يصنفونها ككائنات دقيقة الكية

( $)$ Howard Florey / relaxing (1990) European patent office Reports 0 \&)

(0) Harvard oncompose (199.) O.J.EPO 0^9, plant Genetic system(Tro\%/94) (1990)

EURPEAN PATENT OFFICE Sم Reports rov, Howard Florey /relaxing ibid.

( $\urcorner$ ) Plant Genetic System, ibid 
ظهر أيضاً من السوابق القضائية (Case law) والأنشطة التشريعية الحديثة داخل الاتحاد الأوروبي ومكتب براءة الاختراع الأوروبي.(1) أن هذه الاستثناءات وضع حيالها قيود شديدة التطبيق.

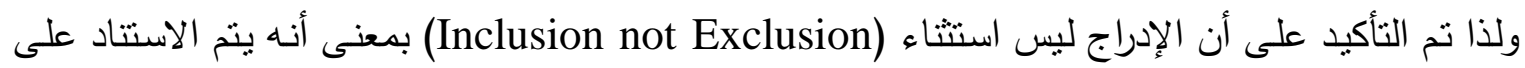
الاستعمال غير الكافي للتعربف بدلاً من الإفراط في الاستعمال بالإضـافة وهذه النظرية تؤكد على الحاجة إلى تساوى الحماية داخل الأسواق العالمية، وهذا التساوي معلن في ممارسة الدول المتقدمة، وإذا كانت معظم الإنم

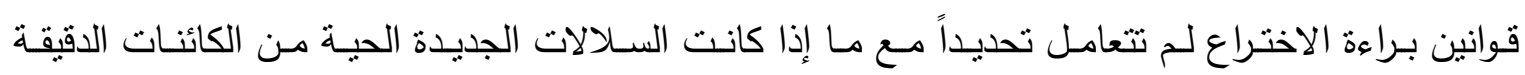
نفسها تكون قابلة للحصول على براءة اختراع أم لا.

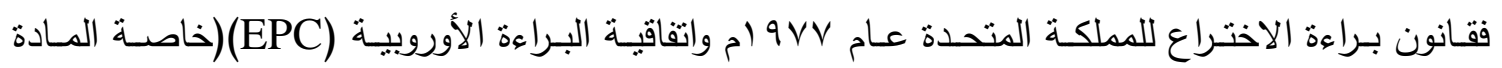

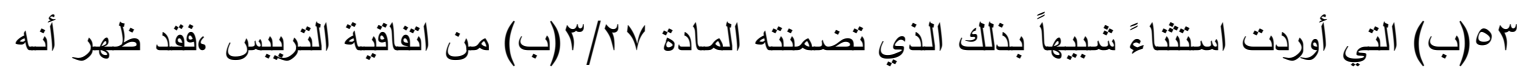

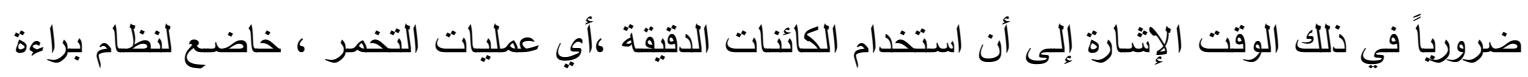

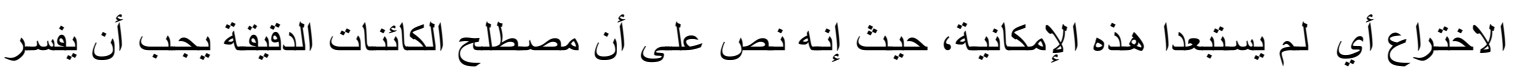

على نحو واسع لكي يتضمن - ليس فقط البكتيريا والفطريات ولكن أيضاً - الفيروسات والخلايا النباتية (广). وهذا يتوافق مـع ممارسـة مكاتب بـراءة الاختراع في منح البراءة في أمربكا وأوروبـا واليابـان، لأن بـراءة الاختراع منحت للخلايـا النباتية والحيوانية، وقد حدث نقاش بخصوص النباتات التي تكون قابلة للحصول

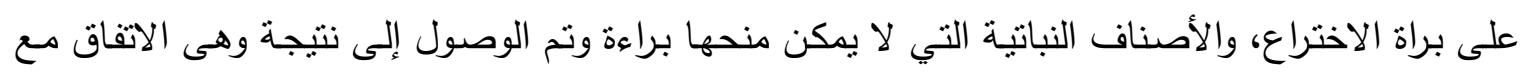

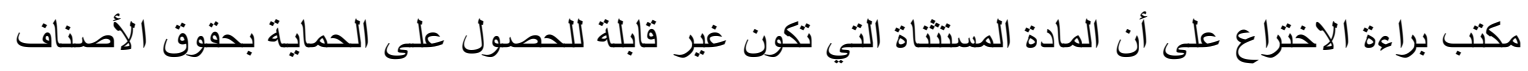
النباتية كما هو محدد في اتفاقية اليوبوف، أو أي شيء يقع خارج مجال اتفاقية اليوبوف يكون قابلاً للحماية بيراءة الاختراع(r). ونستتتج من هذا أن الحماية ببراءة الاختراع تكون للمجموعات النباتية التي تحيط بأكثر من صنف نباتي، وبالتالي يكون من الواضح أن موضوع حماية الكائنات الدقيقة ببراءة اختراع مستقر في الدول المثقدمة، لأن القوة الدافعة خلف نظام براءة الاختراع هي نفسها التي تقرر أن الإدراج لبس استثناء؛ ولذا هم يفرطون في استخدام تعريف الكائنات الدقيقة، بمعنى أنه ينم منح تفسير واسع لمادة البحث القابل للحصول على براءة الإدراج

(1)EU directive the legal protection of biotechnological invention EC/ $\varepsilon / 9 \wedge$ and the decision of the administrative council 17 June 1999 to amend the implementing rules of the European patent convention.

in particular rules $r$ (b) (1) which states that the Directive, shall be used as a supplementary means of interpretation, $1999 \mathrm{OJEPO} \leqslant r v, 1999 \mathrm{OJEPO}$ ov $\mathrm{r}$ the regulation come into effect on I september 1999

( P)Patents for chemical and biotechnology oxford university press 1999 at page Yr 4 and $r r \vee$ Grubb is a European patent Attorney and intellectual property counsel for Novartis international AGIN Switzerland.

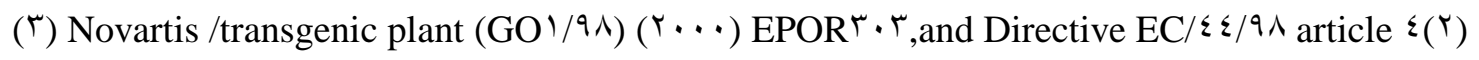
يجب ملاحظة أنه يمكن أن يكون للمحامين دور فى تطوير وتفسير قو انين البراءة حيث إن خبرة المحامين لها دور فى تقديم

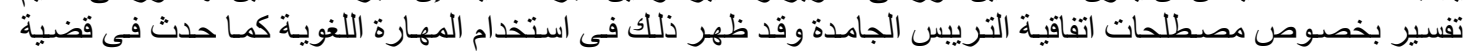

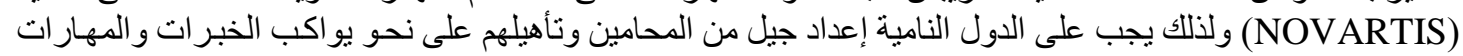


اختراع ومعايير المنح، وَمِنْ ثََّّ أبي استثناء يجب أن يقيد في التطبيق وهذا يعنى أنـه عندما يتم استنثناء أصناف محددة من الحماية، فهذا يخضع لفحص دقيق، وإن كان هذا مجمل الوضع بخصوص موفي موقف الدول المنقدمة فلا يعنى عدم إمكانية أن النظرة البديلة لا يمكن أن تسود.

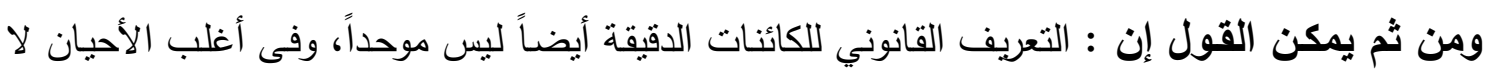

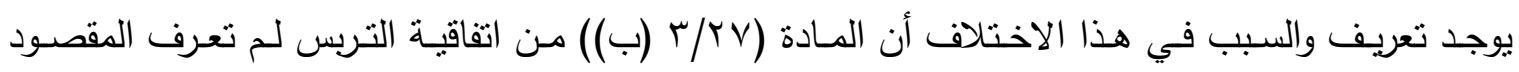

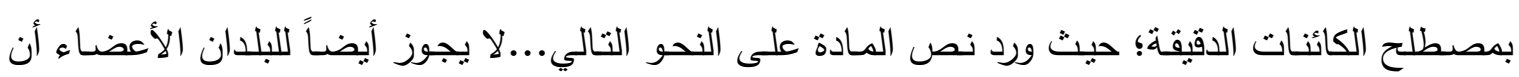

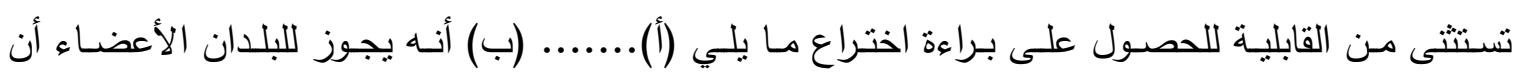

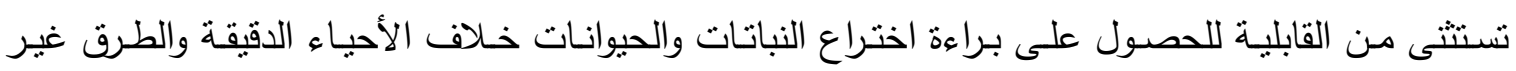
البيولوجية، والبيولوجية الدقيقة.

ولذا ظهرت كثيرُ من المشاكل القانونية بخصوص نطاق القابلية للحصول على براءة الاختراع، وإن كان هنالك أسباب أخرى لهذه المشـاكل، وهى عدم وجود تمييز علمي او منطقي بين النباتات والحيوانات من ناحية، والكائنات الدقيقة من ناحيـة أخرى، حيث يجب أن يكون كل منهم غير قابـل للحصول على وجى براءة اختراع، لأن كل الأشياء الحية (Living Things)، تكون اكتشافات (Discoverers) وليست ابتكارات (')(Invented) أيضـاً لا يوجد إجماع بخصوص مـا يعنيـه مصطلح الكائنات الدقيقة في المجتمعات العلميـة،(؟) ولذا تم التساؤل هل المادة البيولوجية (Biological Material) مثل خطوط الخلية (Cell Lines) والإنزيمات

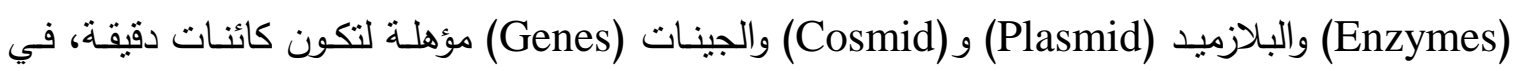

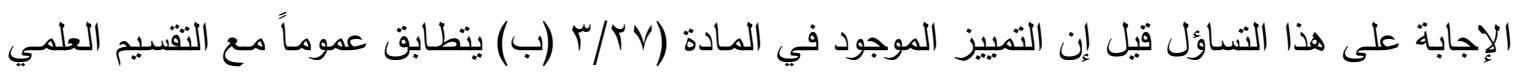
المقبول للكائنات(ب) وفكرة تقيم الكائنات (أشكال الحياة)إلى نباتات وحبوانات وكائنات دقيقة، فكرة شائعة

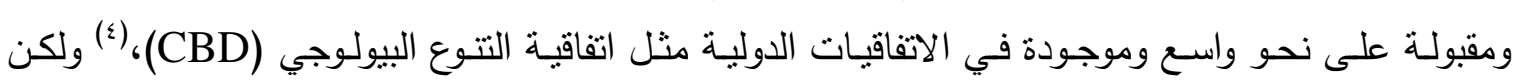

(1) DR.Mae-Wan Ho and DR.Terje Traavik,institute of science in society, UK and institute of gene Ecology Norway why we should reject biotech.patent from trips article $r v / r(b) p .1$ available at: http://www.i.sis.org.uk/trips $99 . \mathrm{php}$

$$
\text { - راجع الوثيقة الصادرة عن اجتمعات مجلس التريبس المقدمة من كينيا نيابة عن المجمو عة الأفريقية }
$$

Kenya on behalf, of the African Group.Ip/c/w/lrr.of the provision of article $r V / r(b)$ communication from Kenya on behalf of the African Group.^nov. 1999

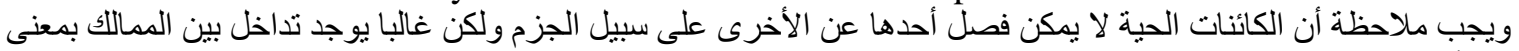

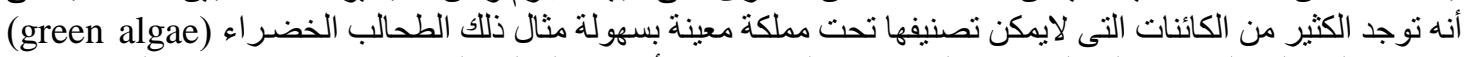

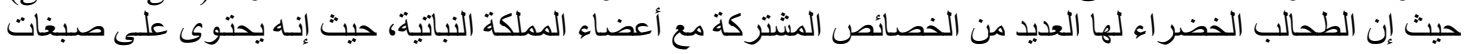
مادة ملونة في خلايا النبات وتكون (photosynthetic)

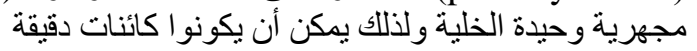

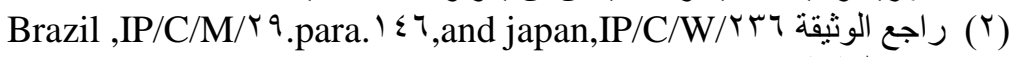

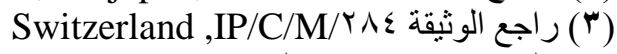

( ) ) على نحو ضيق و عدم التوسع فى تعريفها:

Chakravarthi Raghan r... available at: http://www.twnside.org.sg/title/organism.htm بل الأكثر من ذلك أن القاموس الطبى لم يتوسع فى تعريف الكائنات الدقيقة ويمكن مطالعة موقع النت على النحو التالى: http://www.wrongdiagnosis.com/medicalymicro-organism.htm, as it definition microorganism any single -cell. such as bacteria or protozoa 
غياب تعريف مصطلح الكائنات الدقيقة في اتفاقية التيب، عكس حقيقة أن المصطلح لم يعرف من قبل خبراء براءة الاختراع في أى مكان، حتى في الاتفاقية الدولية للاعتراف بإيداع الكائنات الدقيقة من أجل إجراءات البراءة (اتفاقيـة بودابست) (Budapest Convention) أيضـاً لجنـة خبـراء الويبو لاختراعـات

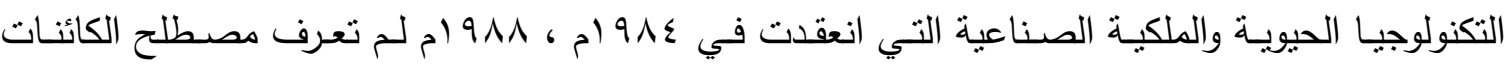
الاقيقة، بالرغم من أن المصطلح استخدم في كثير من المناقثات؛ وقد كان هذا النقص في التعريف السبب

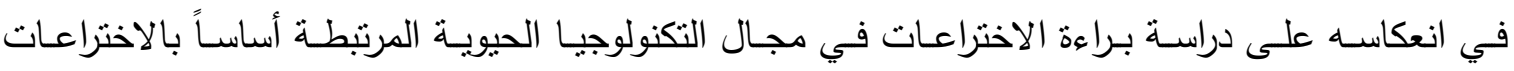

البيولوجية الدقيقة (Microbiological Invention).

وموقف مكاتب براءة الاختراع: للدول المتقدمة يمكن أن بظهر بصورة جلية أكثر على النحو التالي، حيث تم الاتتراك بين كل من مكتب براءة الاختراع الأمريكى والياباني والأوروبي بهدف تعريف ما بسمى بالكائنات الدقيقة، ولقد أبدى مكتب براءة الاختراع الأوروبي ملاحظة بأنه من غير الملائم أن يتم تعربف هذاع المصطلح، حيث إن التطور في مجال البيولوجيا سريع في هذا المجال؛ ولذا يجب تطويره باستمرار ('). فخبراء البراءة أقروا بأن أي تعريف يكون مقبولاً عندما يكون قابلاً للتعديل يومياً، بمعنى أنه يمكن تطويره باستمرار ، خاصة في ظل النطور السريع للأبحاث في هذا المجال، (؟). وإذا كان الخبراء لم يعرفوا على نحو مناسب الكائنات الدقيقة فكيف يكون لمجلس التريبس المحاولة فيما يتعلق بهذه المهمة؛ ولذلك تم التساؤل كيف تستطيع كل من الدول الأعضاء وجهاز تسوية المنازعات في منظمة التجارة العالمية أن يفسروا مصطلح الكائنات الدقيقة، خاصة في ظل غياب التعريف الجازم.

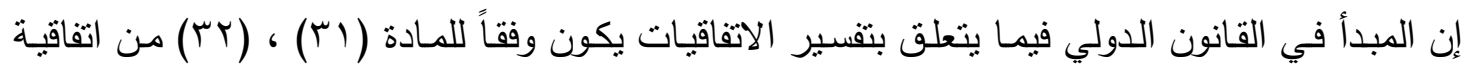
فيينا (Vienna Convention) بخصوص قانون المعاهدات، حيث إن هاتين المادتين أوضحتا أن القاعدة

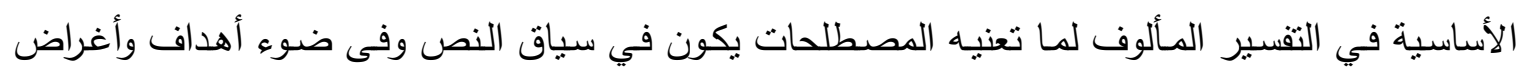

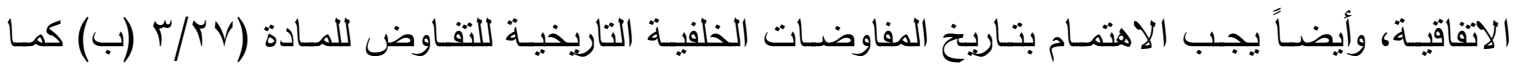
أوضحت المادة (اس/ع) من اتفاقية فيينا. كما أن القاموس عنى بتعريف الكائنات الدقيقة وميز بينها وبين النباتات والحيوانات بما يفى بأغراض التيبس، فقاموس إكسفورد (The Concise Oxford Dictionary) عرف الكائنات الدقيقة على نحو مألوف حيث عرفها بأنها الكائنات التي لا ترى بالعين المجردة، على سبيل المثال الفيروس والبكتيريا،(ب).

(1) meeting with dated $r \cdot$ jun. 1991, prepared jointly by the European patent office the Japanese patent office. And the US patent and trademark office page. rof that document.regards (Definition of micro-organism)

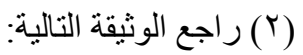

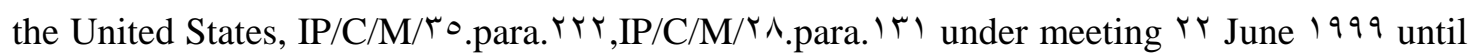
r mar $r \ldots r$ of the work of the trips council

لقد تم تطوير المجهر الخفيف العادى ثم تلى ذلك تطور ات أخرى مثل تطوير المجهر متحد البؤر (confocal) و المجهر

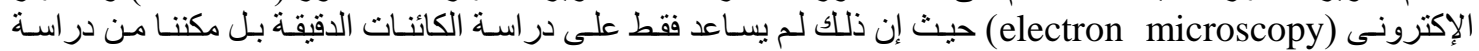


ولكن قيل إن المفاوضين في اتفاقية التيبس وجهت إليهم أسئلة ولكن لم يجيبوا عليها بخصوص مـا إذا كانت براءة الاختراع يجب أن تمتد إلى خطوط الخلية والكوزميد والجينات والبلازميد والإنزيمات؛ ولذلك لم

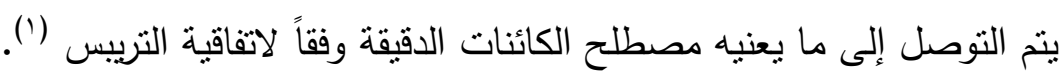
كمـا أن الإثـارة إلى القاموس ليسـت مفيدة مـن أجل التعامل مـع العديد مـن أنواع وأنثكال الحياة غير الثابتة، كما أنه لم بيتاول الكائنات الدقيقة على سبيل الحصر . ولكنه ضـرب أمتلـة فقط على الفيروس والبكتيريـا، وليس ضرورياً أن يرتبط ذلك بقابلية حصول الكائنات الدقيقة على براءة اختراع وبخصوص الإجابة على التساؤل السابق ظهرت وجهات نظر عديدة نسوق منها ما يلىى: ا- الكائنات الدقيقة مثل المواد البيولوجيـة الأخرى والكائنات الحيـة (Living Organisms) يجب أن تشتثتى من القابلية للحصول على براءة اختراع.(r) r- مصطلح الكائنات الاقيقة يجب أن يكون واضحاً بخصوص استثناء خطوط الخلية والإنزيم والبلازميد والكوزميد والجينات(广).

r- يمكن لكل دولة عضو أن تحدد وتطبق المصطلح في نظامها القضـائي وفقاً للمسادة ( (1)من اتفاقيـة بودابست (Budapest) ولا تبحث عن تعريف المصطلح، ولأن القضايا في هذا الموضوع معقدة لذلك

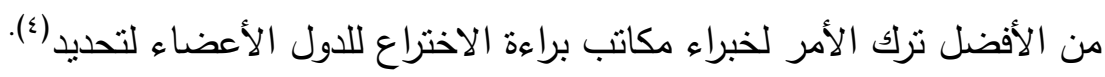

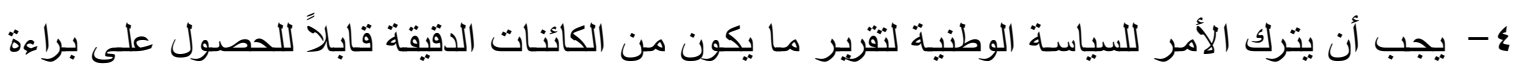
اختراع (o). ه- يترك الأمر لاقتراحات كل دولـة ولكن يجب أن تكون هذه الاقتراحات مفيدة للفهم الجماعي لطبيعـة المصطلح وواضحة الارتباط بالإطار البيئي ومتوافقة مع مبدأ المنافسة (؟).

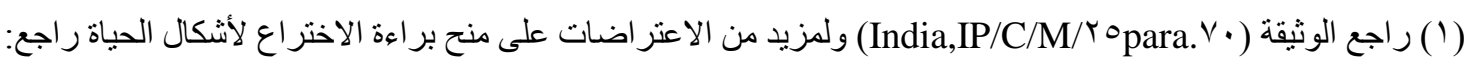
Dfid information Department, $9 \varepsilon$ Victoria Street, London SW'E ${ }^{\circ} J L$ L.briefing.sep. ${ }^{r} \cdots r . p^{\wedge}$ with title Does trips allow for the patenting of life forms? Website : http://www.dfid.gov.uk/

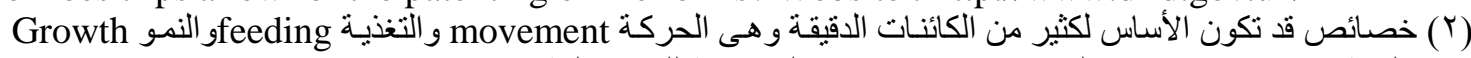

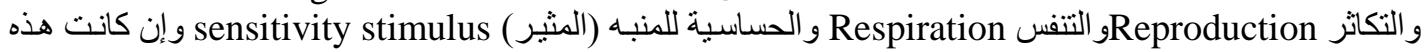

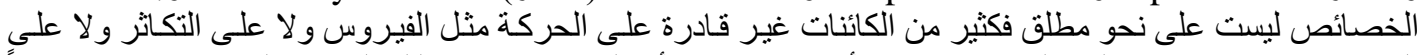

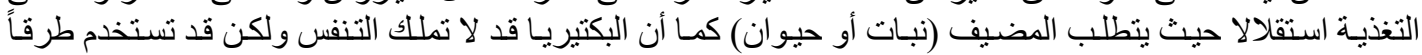
website: http://www.fasload.org/mi/micro.organism.htm كيميائية بديلة

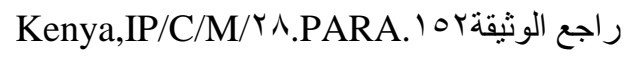

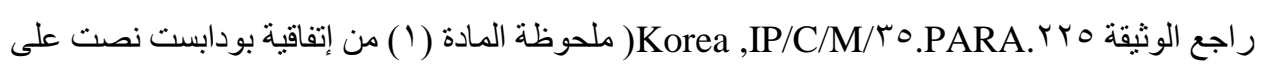

The states party to this treaty (herein after called :the contracting states:constitute union for the international recognition of the deposit of microorganisms for the purposes of patent procedure)

( $)$ India, IP/C/M/ . Further information Review of the provision of the article $r v / r(b)$ (communication from India of council TRIPS) rNOV. 1999

( 7 See: Australia, IP/C/M/ 9 .para. 19 . 


\section{مما سبق يمكن القول بأنه يوجد اتجاهان بخصوص تعريف الكائنات الاقيقة:} اتجـاه يميل إلى تعريفها على نحو واسـع، وهذا الاتجـاه تمتلـهـ الدول المتقدمـة، والاتجـاه الثاني يعرف

الكائنات الاقيقة على نحو ضيق، وهذا الاتجاه تمثله الدول النامية، حيث إنه يتفق مع مصالحها. وإذا كانت اتفاقية التربس لم تحدد ما المقصود بمصطلح الكائنات الدقيقة، فهي أيضاً لم تحدد ما المقصود بكل مـن المصـطلحات التاليـة: (الطـرق البيولوجيـة الجوهريـة، والطـرق البيولوجيـة الدقيقة، والطـرق غيـر البيولوجية ).

\section{العمليات الإنتاجية البيولوجية: البية}

الحقيقة أن فاحصي براءة الاختراع يواجهون صعوبات جمة في التعامل مع التقتيات البيولوجية الجديدة(') وهو وضع تعكسه صياغة اتفاقية التيبس فهي لا نقدم أي عون في هذا الإطار ، لأنها لا تتضمن أي تعريف

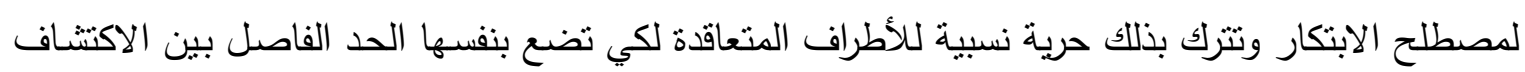
غير المؤهلة لبراءة اختراع والابتكارات الفعلية في المجال البيولوجي (؟). كذلك يتيح غياب أي اتفاق جماعي بشأن براءة الاختراع البيولوجية مجالاً واسعاً للبلدان لكي تقوم بوضع خيارات السياسـة الملائمسة حيث إن اتفاقيـة التيبس تتيح للأعضـاء فرصـة استثناء المنتجات وعمليات إنتاج معينة من براءة اختراع بالإضافة إلى أنها تمنح الأعضاء أيضاً الخيار في استبعاد من الحماية ببراءة اختراع

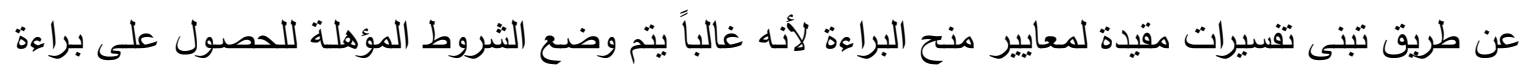

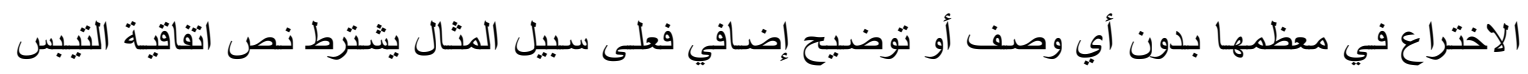

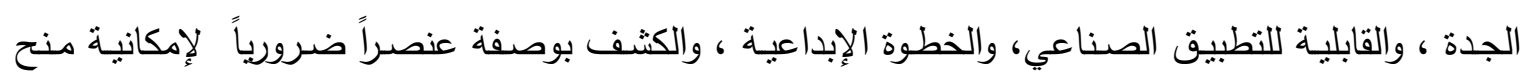

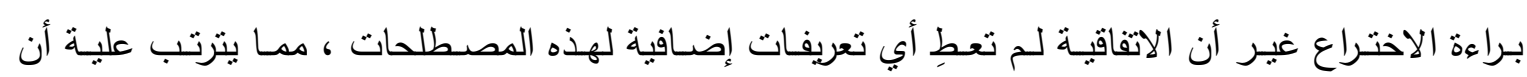
القوانين المحلية سوف تتخذ مواقف مختلفة تجاهها. وبالتالي فإن التشريعات التي سيتم وضعها ستكون تبعاً لمصلحة البلد ،تشريعات مقيده بصوره أو أخرى وهو ما سيؤدى في نهاية المضاف إلى إثارة مناقثنات تتصل بتطبيق معايير التأهيل لبراءة الاختراع، المهم

هنا أن اتفاقية التيبس جسدت التزامات بمنح براءة اختراع للطرق غير البيولوجية والبيولوجية الدقيقة (َ).

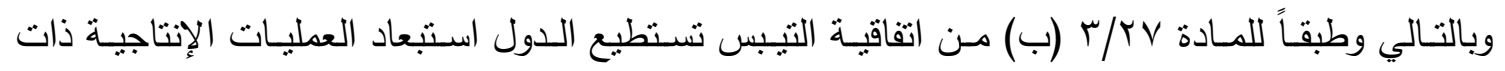

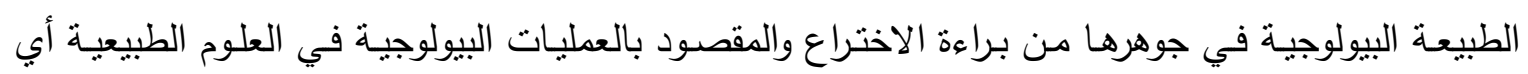
نشاط بيولوجي يقوم به كائن حي سواء كان في مستوى الجزيء أو الخلية أو الكائن الكامل. نظراً لعدم وجود مصطلح علمي يسمى في جوهرها فإنه يحتاج إلى تفسير إضافي ، فالعملية التي هي في

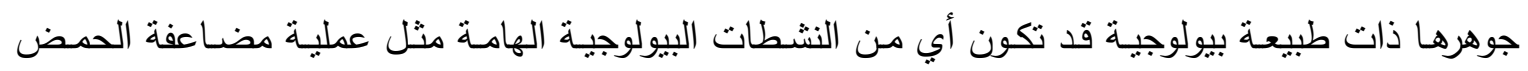
النووي الريبوزى منزوع الأكسجين (DNA )، وعملية النسخ والترجمة التي تحدث داخل الخلية، والضرورية

( ) see: gttp://www.idrc.ca/books/Vro/chap s.html

( $r$ UNCTAD,THE TRIPS AGREEMENT and developing countries NOW YORKGENEVA $\mathrm{UN}, \mathrm{P}{ }^{\mathrm{L}} \varepsilon$ 
لتواجد الكائنات الحية، وعلى مستوى الكائن الحي تعتبر النشطات الفسيولوجية (نشطات وظائف الأعضاء) بما في ذللك التنفس ،والتمثيل الضوئي ،والتكاثر ...إلخ هي عمليات ذات طبيعة بيولوجية في جوهرها. وتعبر اتفاقية التريبس بتوسيعها للاستبعاد الاختياري للموضوع الخاضع لنظام براءة الاختراع لكي يتضمن العمليات التي هي في جوهرها ذات طبيعة بيولوجية ،عن الفقرة الواردة في المادة سمه(ب) من اتفاقية البراءة الأوروبية، غير أنه يجب أن نتذكر هنا أن المادة سه (ب) السابقة تهدف لتحقيق أهداف مختلفة تماماً ،وهى

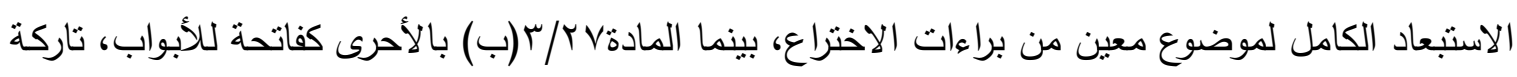
مواضيع معينه لحرية تصرف الدول الأعضاء. غير أنه من أجل التشريع تم تفسير نطاق "العمليات التي في جوهرها ذات طبيعة بيولوجية" تفسيراً ضيقاً ومحدوداً ويهدف ذللك في الأسـاس نوسيع نظام براءات الاختراع ، حيث يقدم المجلس الفني لمكتب براءة الاختراع (TBEPC) تعريفاً سلبياً لما يعد عملية هي في جوهرها ذات طبيعة بيولوجية ، بوصفها عملية

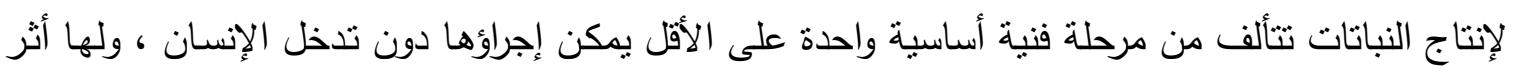
حاسم على النتيجة النهائية. وبالتالي يتم النظر للعملية التي هي في جوهرها بيولوجية من هذا المنطلق ،باعتبارها عملية تتم من غير

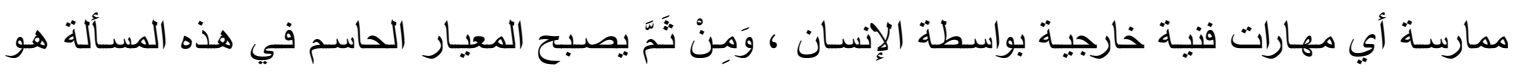

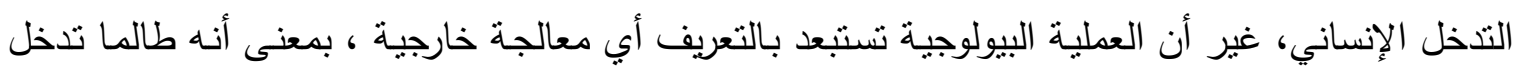
التقنية الإنسانية في عملية طبيعية مستقلة فإنها تلغى طبيعتها وتحولها إلى عملية صناعية؛ لذلك يبدو أن التدخل الإنسـاني لا يصـلح للتميز بين العمليـة التي هي في جوهرهـا عمليـة بيولوجيـة وبين العمليـة غير الإني البيولوجية، وإن كان هناك من يرى أن التميز الصناعي (Artificial Distinction) يصلح للتقرقة بين الطرق البيولوجيـة الجوهريـة من ناحية والطرق البيولوجية الدقيقة والطرق غير البيولوجية من ناحية أخرى؛ ولذا يجب أن يتم عزلها،(') وتتقيتها (r). ومع ذلك هناك قدر من الثلك في القول بأن تفسير المادة سم(ب) من اتفاقية البراءة الأوروبية يمكن أن

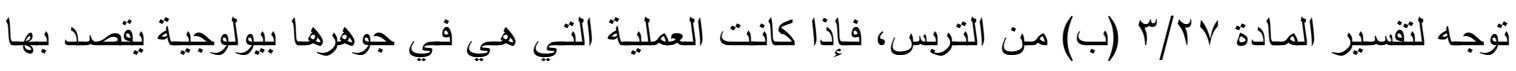

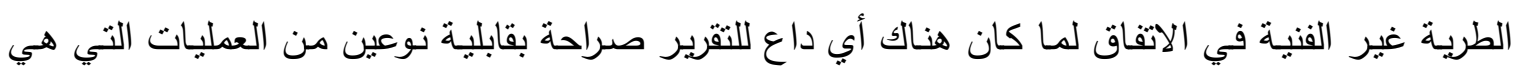

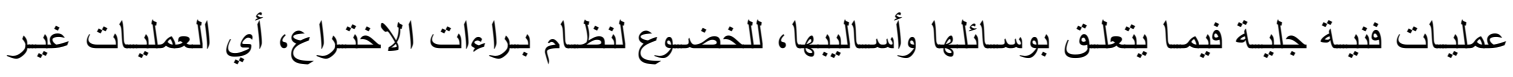

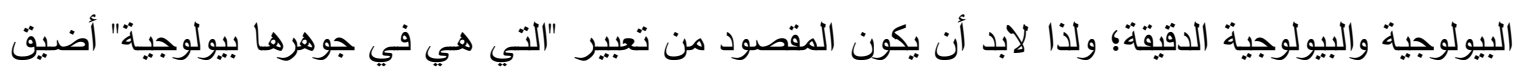

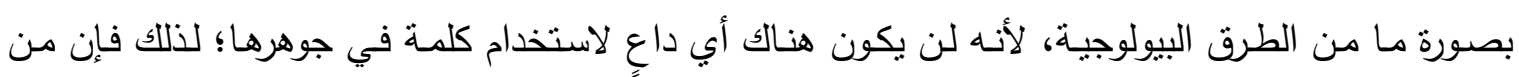

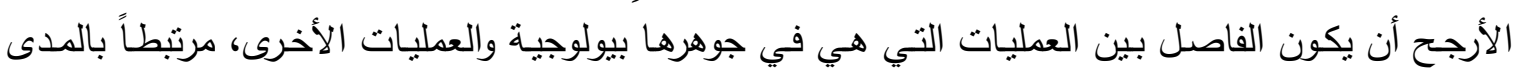
الذي تحل فيه التطبيقات التقنية في العملية المعنية.

أيضاً هنا يبدو أنه غير ممكن إلى حد كبير ، وضـع حد تقنى فاصل تصبح عملية ما بعده ليست في جوهرها ذات طبيعة بيولوجية وفقاً لاتفاقية التيبس والأرجح هو أن الاتفاق يعكس باستعماله صباغة مماتلـة 
لوجهات النظر المختلفة بشأن نطاق المادة سم(ب) من اتفاقية البراءة الأوروبية وتترك للدول الأعضاء مههة تعريف ما هو جوهري ذات طبيعة بيولوجية في الإطار المخصص، ولكن برغم ذلك يضيف تعريف العملية البيولوجية المذكور أعلاه مؤهلاً إضافيا هو معيار أن تكون في جوهرها، إلى الاستثناءات المقررة في براءة الاختراع ، فبغض النظر عن الطريقة التي سيتم بها تعريف في جوهرها في هذا الإطار فإن الآثار القانونية ستكون في أخر الأمر تضييقاً كبيراً لنطاق الفعل المتاح للأعضاء فيما يتصل بتطبيق هذه الأحكام ، وستقل البدائل الى درجة يتم فيها تقويض الاستثناءات المقررة على براءة الاختراع.

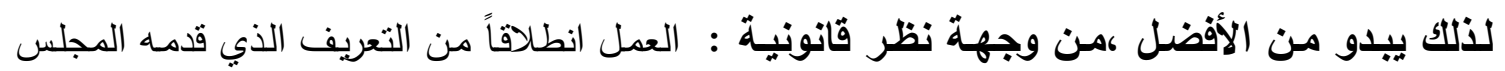
الفني لمكتب براءات الاختراع الأوروبي، والسعي لتوضح الموضوع فيما بتعلق بنطاق الاستثناءات المحتملة، وتتشأ فيما يتعلق بالتوضيحات القانونية مشكلة إضافية تخنص بمجالات التقنية البيولوجية المختلفة (الهندسة الوراثيـة) حيـث تمثنل العمليـات متعددة الخطوات التي تتـداخل فيهـا العمليـات الطبيعيـة والمعالجـات الفنيـة وتتثابك، إحدى سماتها الجوهرية. العمليات الإنتاجية البيولوجية الاقيقة وغير البيولوجيةة: العمليات البيولوجية الدقيقة وغير البيولوجية

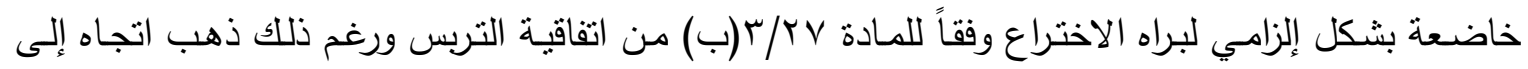
القول بأنه يجب أن تعامل الطرق البيولوجية الدقيقة والطرق غير البيولوجية بنفس الطريقة التي تعامل بها الطرق البيولوجية الجوهرية، (') . وقيـل أيضــاً: إن الطـرق البيولوجيـة الجوهريـة هـي التي تحدث طبيعيـاً أو التـي تتفـذ بواسطة الكائنـات ولكن هذا التحديد مشكوك فيه أيضاً، أما الطرق غير البيولوجية هي (Carried Out by Organisms) عكس الطرق البيولوجية الجوهرية ، بمعنى أنها هي الطرق التي لا تحدث طبيعياً والتي لا تتم عادة بواسطة

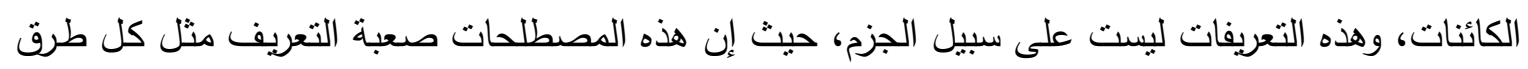
التكنولوجيا الحيوية أما الطرق البيولوجية الدقيقة يفترض أنها واحدة من الطرق التي تتفذ بواسطة الكائنات

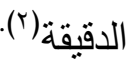

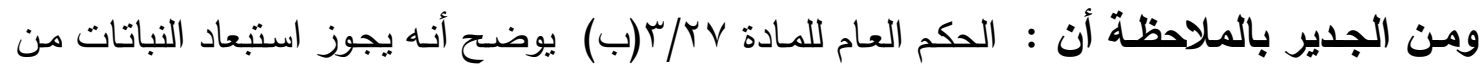
براءة الاختراع ، ومكمن الاستثناء في هذا النص في أن هناك عملية معينة تخضع بصورة إلزامية لبرايات

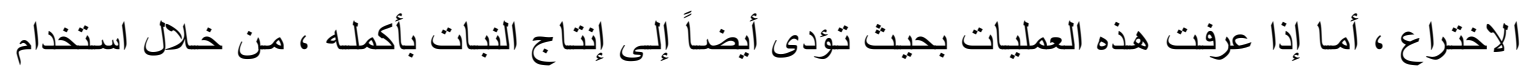
التقنيات البيولوجية الدقيقة في مرحلة ما ، فإن ذلك يعنى توسيع الاستثناء بطريقة تجعل الحكم العام لا قيمه إدها

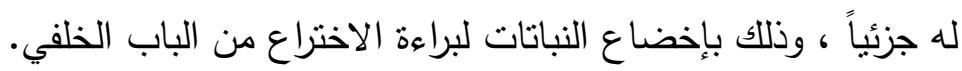

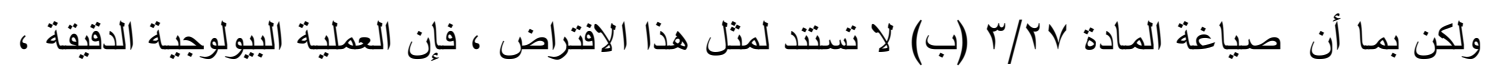

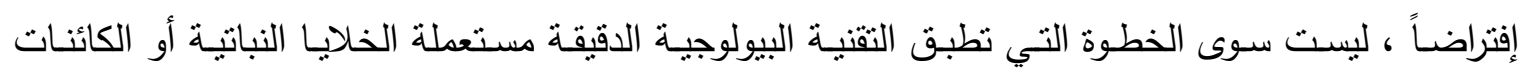
الدقيقة؛ لأن النظر يكون في المنتجات التي يتم الحصول عليها مباشر ة من العملية الإنتاجية الخاضعة 


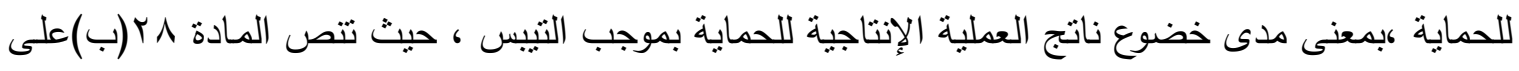
حماية المنتجات التي يتت الحصول عليها مباشرة من العملية الإنتاجية الخاضعة للحماية ، ويعنى إستخدام تعبير مباشـرة "وليس" المنتجـات التي يتم الحصـول عليها فحسب ، يعنى ضـمان أن حمايـة نـاتج العمليـة الإنتاجية تتطبق فقط على الناتج المباشر للعملية الإنتاجية الخاضعة لحماية براءة الاختراع ، كالخلية المعدلة

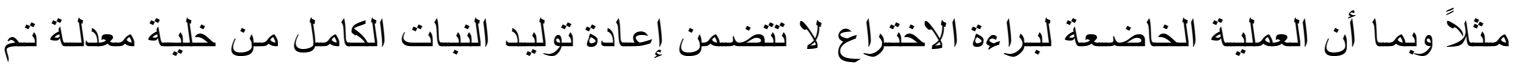

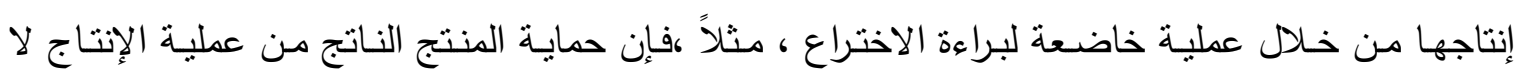
تشمل النبات الكامل بل تقتصر على خلية النبات ، التي هي أخر خطوة دخلتها التقنيات البيولوجية الدقيقة؛ وبالتـالى تخضــع لبـراءة الاختـراع بصـورة إلزاميـة ، الخلايـا، وسـلالات الخلايـا، التـي تم إنتاجهـا بإسـتخدام التقنيات البيولوجية الدقيقة. وعمومـاً يرى الباحثان: أن الطرق غير البيولوجية هي الطرق التي لا تعتمد على الوسائل الطبيعية في إنتاج النباتات والحيوان منل التلقيح والإخصاب والتهجين، (') وإن كان هذا التعريف مشكوكاً فيه علمياً، لأنه لابد أن تتضمن هذه الطرق عمليات (خطوات) بيولوجية بمعنى أنها لا تعتمد على الخطوات غير البيولوجية

على نحو مطلق (广). وعمومـاً يهرف نظام بـراءة اختراع العمليـات البيولوجيـة: إلى حمايـة هذه العمليات في المقام الأول إذ أن

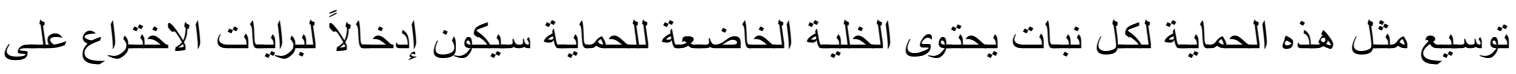
خلايا النبات من الباب الخلفي ، فإذا كانت مثل هذه الحماية هي المقصودة لكانت نظمت من خلال تعريف

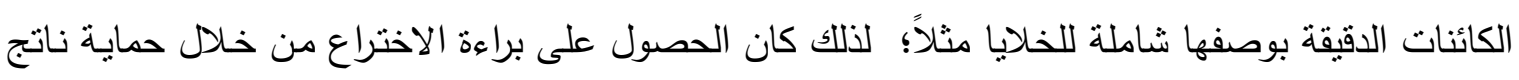

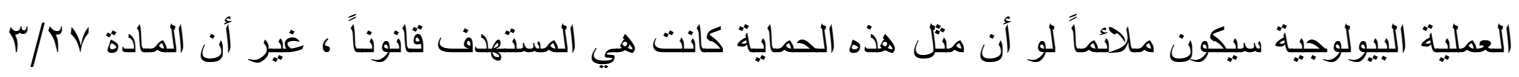
(ب) نصت على عكس ذلك ،وذللك بأن أجازت للأعضاء استثناء النباتات من براءة الاختراع.

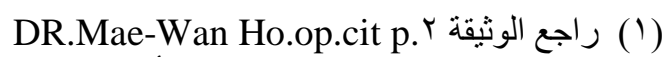

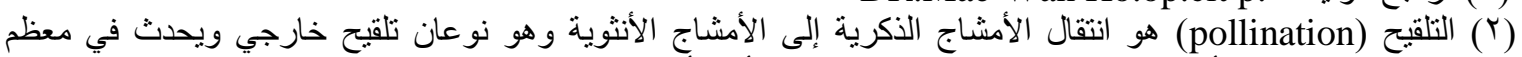

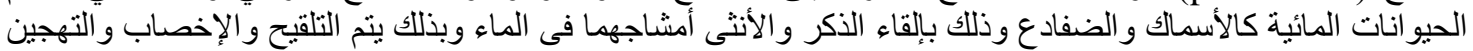

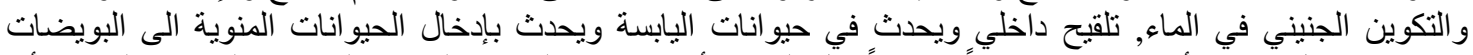

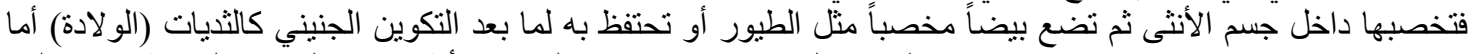

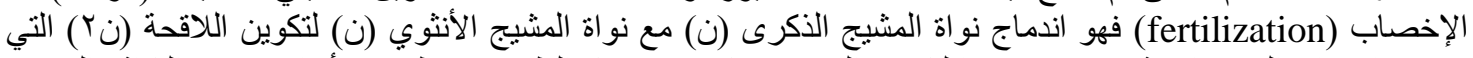

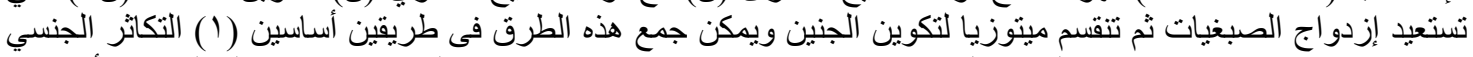

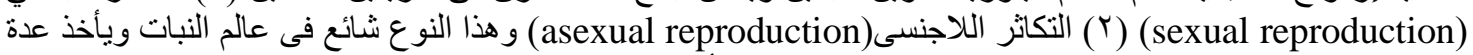

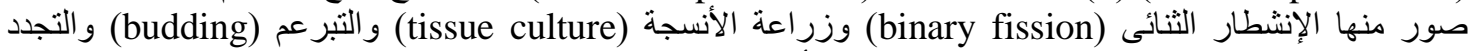

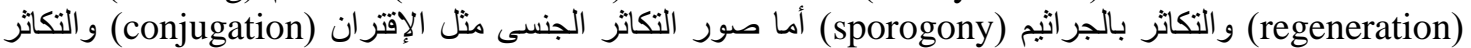

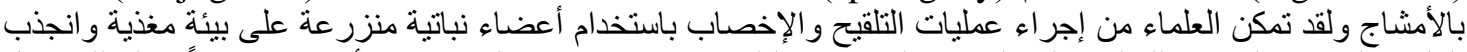

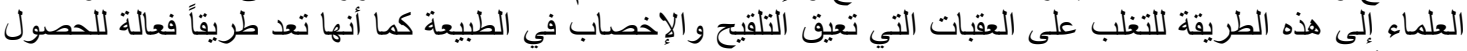

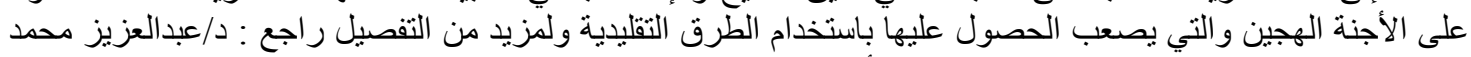

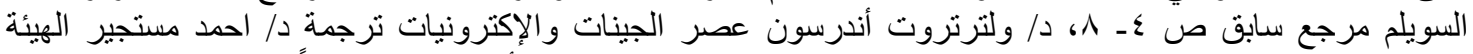

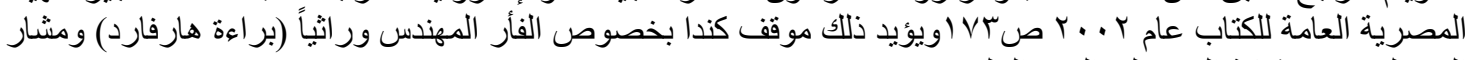

(The Harvard mouse cannot be patented in Canada) إليه على موقع شبكة النت على النحو التالي : بلن

http://www.southcentre.org/info/southbulletin/bulletin $\leqslant \wedge /$ bulletin $\leqslant \Lambda_{-} .{ }^{\circ} . \mathrm{htm}$ and also Newsletters and

bulletins /march $r \ldots$. $/$ European patent office Canda-patentability of higher lif form Available at: http://www.ladas.com/bulletins/r $\ldots \varepsilon / \cdot r \cdot \leqslant$ bulletin/canda_higherlifeforms.html 
من هنا لن يكون توسيع براءة اختراع ناتج العمليات البيولوجية دخول من الباب الخلفي فحسب بل أيضاً توسيع للاسنثناء على حساب الحكم العام ، وبما أن صباغة المادة VYr/r(ب) لا تتيح مثل هذا الفهم ،فإن اتفاقيـة التيبس لا توسـع الحمايـة الإلزاميـة لنـاتج العمليـة البيولوجيـة الخاضـعة لبراءة الاختراع ، لكي تتـمل

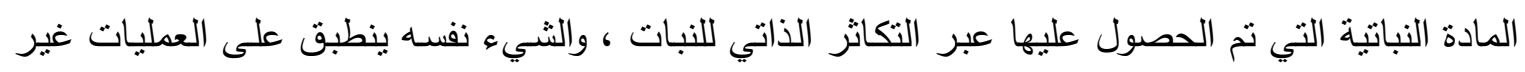
البيولوجية التي يمكن إعتبارها ذات طبيعة فنية. ولا يتوافر خط فاصل واضح بين العمليات الإنتاجية غير البيولوجية والبيولوجية الدقيقة ،ولكن يمكن بصورة عامـة ، إعتبار كل طريقة للهندسـة الوراثيـة داخلة في العمليات غير البيولوجيـة ويمكن أن نأخذ في المقام

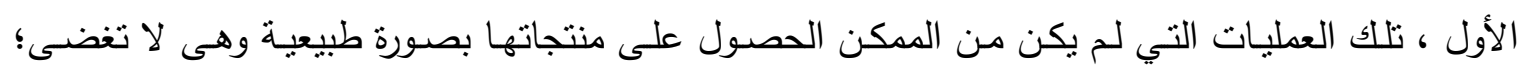
بالتالي أساليب التربية التقليدية ،كعمليات غير بيولوجية. 


\section{المبحث الثاني}

\section{مدى أمكانية إعمال الحماية القانونية للكائنات الدقيقة ببراعة اختراع}

تباينت طرق الحماية القانونية للكائنات الدقيقة في الدول المتقدمة عنها في الدول النامية، حيث ان الدول المتقدمة كانت سباقة في التصدي لوضع تشريعات وضوابط لهذه الحماية منذ فترة كبيرة ، وبالرغم من ذللك فأن هناك عدداً من الدول النامية تصدت أيضاً لوضع بعض من طرق الحماية الخاصة بالكائنات

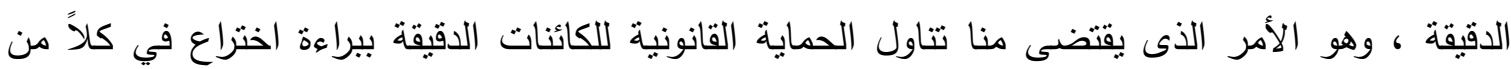

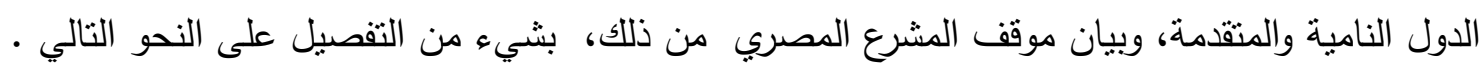

\section{المطلب الاول}

\section{حماية الكائنات الاقيقة في الاول المتقدمة}

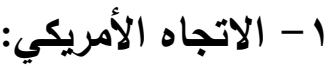

مرت حمايـة الكائنات الدقيقة ببراءة اختراع في امريكيا بمراحل متعددة رغبـة في توسيع نطاق الحمايـة ومداها، فقد كانت الحمايـة في البدايـة تمنح لطرق استخدام الكائنات الدقيقة وللمنتجـات التي يتم الحصول عليها باستخدامها، ففي الولايات المتحدة الأمريكية حصل الكيميائي الفرنسي لويس باستير على براءة اختراع

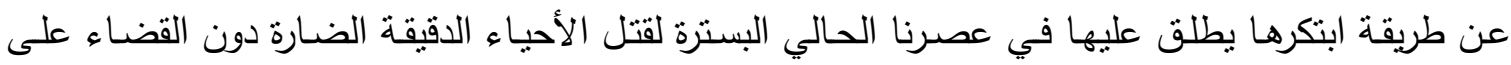
الأحياء الدقيقة اللازمة لعملية التخمر (Fermentation)('). وأحكام القضـاء الأمريكي منذ بدايـة النصف الثاني من القرن العثـرين قررت قابليـة المنتجـات التي

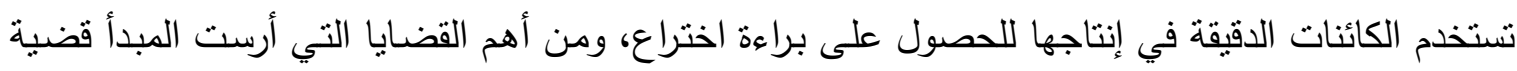
حيث قضت الدائرة الرابعة لمحكمة الاستئناف الفيدرالية في هذه لهره (Merck \& co.v.Mathieson Che..) القضية بصحة براءة اختراع منتج عبارة عن دواء يحتوى على عناصر لها فاعلية فيتامين (ب r Y) يستخدم في علاج حالات فقر الدم (الأنيميا الحادة) ويتم الحصول عليه باستخدام نوع من الفطريات، يتم الحصول

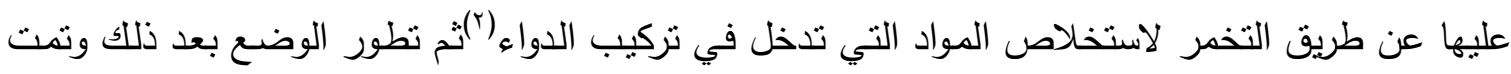

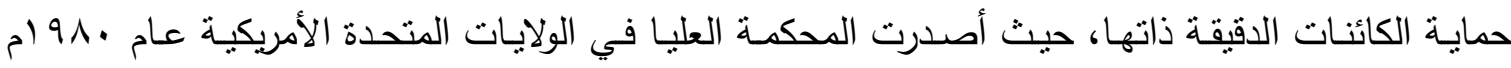
حكماً في قضية(r)(Diamond V. Chakrabarty) مفاده أن المادة الحية التي يرجع وجودها إلى التدخل

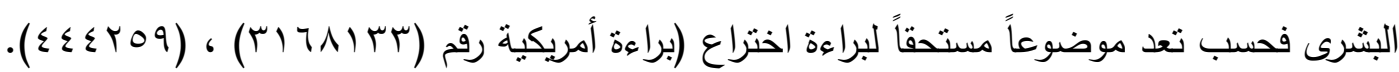

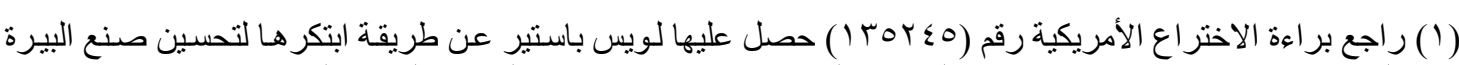

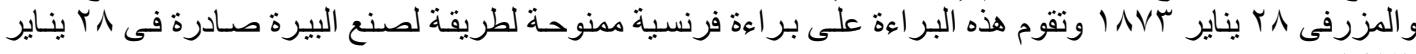

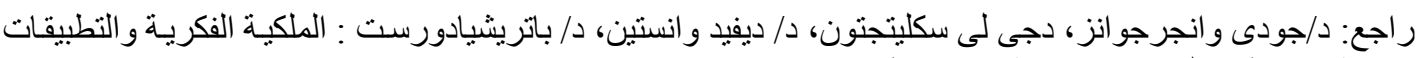

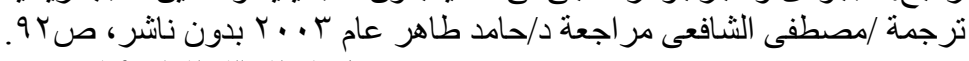

( $r$ ) US court of appeals further circuit 1901. Y $0 \mathrm{rf} . \mathrm{r}_{\mathrm{d}} 10 \mathrm{r}$

( $($ ) Diamond v. Chakrabarty, $\leqslant \leqslant \vee$ U.S. $r \cdot r(19 \wedge \cdot)$, was a United States Supreme Court case dealing with whether genetically modified organisms can be patented.

https://supreme.justia.com/cases/federal/us/ $\leqslant \_v / r \cdot r /$ case.html 
وقد نتاول هذا الحكم كائناً حياً دقيقاً أو بالأحرى بكتيريا تم تعديلها وراثياً لتخفيف الهيدروكربورات، وهذا الحكم وضع مبدأ مهماً في مجال التكنولوجيا الحيوية، حيث أقر بأن الاختراعات التي تم التوصل إليها عن طريق العمل الإنسـانى هي وحدها التي تستحق البراءة، أمـا المواد التي يتم التوصـل إليها في صـورتها الطبيعية لا يمكن استصدار براءة عنها لأنها تعد مجرد اكتشافات، (').

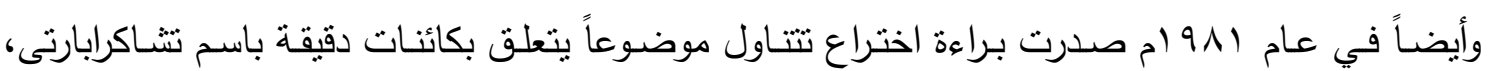
وكانت لسـلالة بكتيريـة مهندسة وراثياً يمكنها فصل المواد الهيدروكربونية؛ وبالتالى استخدامها في تطهير

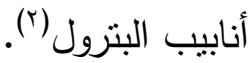

بمعنى أن الاختراع يجب أن يكون له أهمية علمية ويؤدى الى التطور وأن تتوافر له المعايير اللازمة لمنح

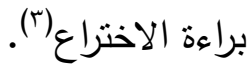

ثم صدر حكم قضائي آخر في أمربكا في مجال التكنولوجيا الحيوية لمسألة شديدة الأهمية فلم يكن الأمر كر كما كان في قضية نشاكرابارتى مجرد كائن حى دقيق ولكن كان لشكل أرقى من أشكال الحياة الراقية، ألا وهو المحار (كائن حى رخوى متعدد الصبغيات والكروموسومات Polyploidy Oyster) حيث تم التوصل إلى اختراع يتت بموجبه إدخال بعض الكروموسومات الإضـافية إلى المحار لتغير طعمـه، خاصـة في أوقات معينة من السنة حيث كانت تؤدى مرارة طعمـه إلى تجنب استهلاكه (ورغم صدور حكم بعدم منحه براءة اختراع) وبالرغم من صدور حكم المحكمة العليا في أمريكا برفض طلب حماية المحار لعدم وجود نشـاط

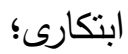

(1) See Case Diamond V.Chakrabarty $\leqslant \leqslant \vee$ US $M 1 \cdot, 19 \Lambda$. The United States the Supreme Court ruled to distinguish between UN patentable and patentable. Subject matter on the basis of products of nature whether living or not and human.

$(r)$ see: US.patent No. $\{, 0 r 0, \because \uparrow$ Ananda Chakarabarty et ale,for a genetically engineering strain of bacteria capable of dissimilation of Environmentally persistent chemical compound Agu. $1 \%$, 1910

$\left({ }^{\top}\right)$ The US supreme court has held that a discovery of some new, natural product is not

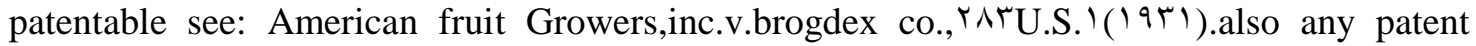
issued must meet three criteria outlined by congress in the patent act. First apatent must be either a new an useful invention or any new and useful, improvement of an existing invention second an invention may not have been previously known or patented by other in the US, nor described in any publication nor than any year prior to the patent application, third,an invention must be distinct from all prior art, such that it would not have been obvious to a person having ordinary skill ,in the field. See: ro US.c.\& $1 . r(191 \wedge)$. 
أعلنت الهيئة الاستئنافية لبراءة الاختراع عـام 9 ام ام أن المحار مـادة بحث قابلـة للحصـول على بـراءة

وبالتالي مكتب البراءات والعلامات التجارية الأمريكي أصدر قراره على نحو يساير حكم المحكمة السـابق؛ حيث استتد في إصداره على نفس منطق الحكم السابق، ولكن أكد فيه أن الحيوانات مادة نستحق البراءة

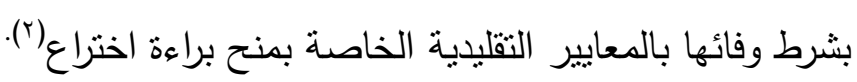

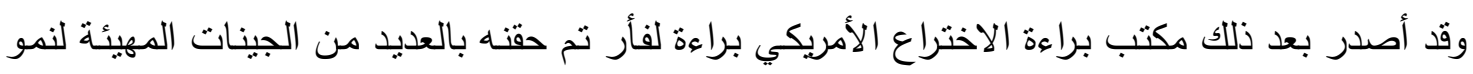

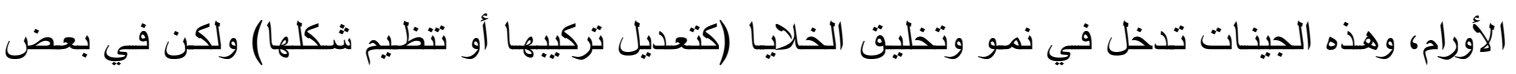
الظروف تتسبب في انتشار فوضوى للخلايا أو في خلل في التخليق و في الإصـابة ببعض السرطانات، وفى في

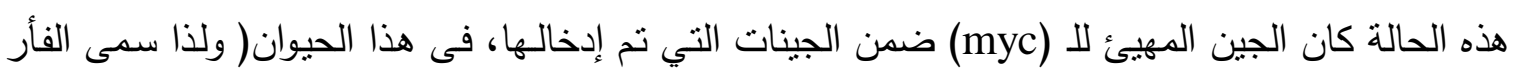

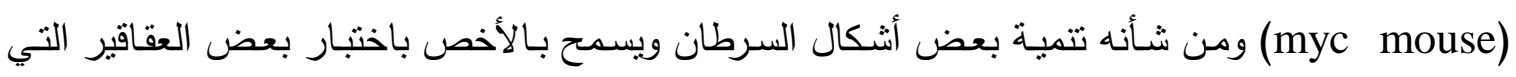

تسبب الإصابة بالسرطان، وكذا اختبار الخصائص المضادة للانقسامات غير المباشرة للعقاقير الأخرى(َ). ويمكن القول بأن مكتب البراءات والعلامات التجارية الأمريكى منذ صدور قرار المحكمة العليا ـ ـ19 ام كان

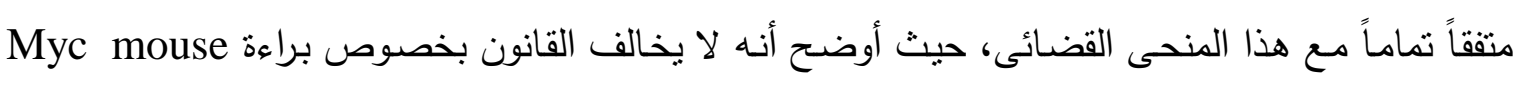

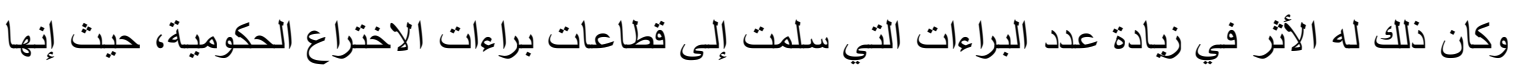

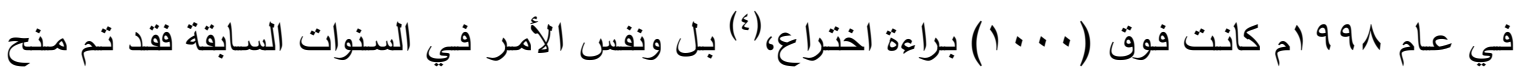

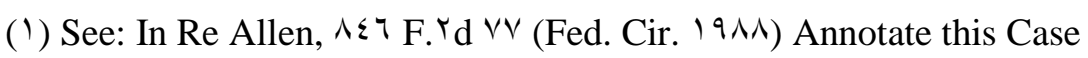

U.S. Court of Appeals for the Federal Circuit - $\wedge \Sigma \uparrow$ F. $r d \vee \vee(F e d . ~ C i r . ~ 19 \wedge \wedge)$

March $1\{, 19 \wedge \wedge$ The decision of the Board of Patent Appeals and Interferences rejecting four claims of a patent application for a type of oyster, Ex parte Allen, $r$ USPQ $r d ~ I \leqslant r o(19 \wedge V)$, is affirmed, http://law.justia.com/cases/federal/appellate-courts/F $/ \wedge \leq \checkmark / \vee \curlyvee / \Upsilon q \vee . ৭ \wedge /$

( $r$ ) Year book $1911 /$ II , page $r$ r 1 . $r$ r , executive committee of Sydney Ap. $1 \cdot-10,1911$ Question Q 9 r Biotechnology (RE-Affirms the principle that inventions relating to living organisms be they micro-organisms,plants, animal or parts there of ..... them should be patentable the sole condition that they comply with the usual criteria of patentability

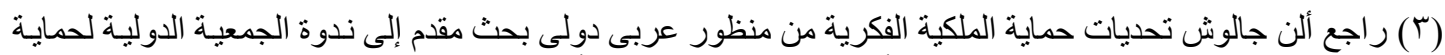

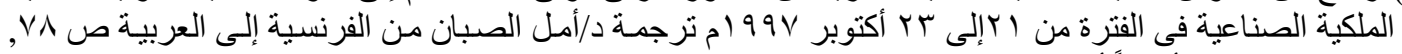

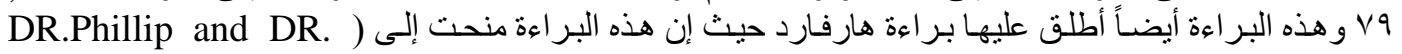
(Timothy Stewart Ho.

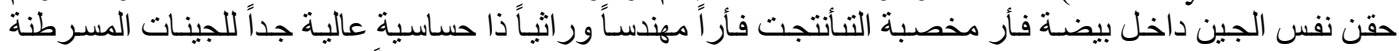

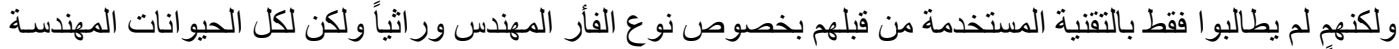
ور اثثياً غير البشرية المنتجة بتقنيتهم (توجب منحهم بر اءة اختر اع وبالتالي حماية بر اءتهم ) لمزيد من التفصيل راجع :

Sahil Gupta. ${ }^{\circ}$ april $r$..r. The problems raised biotechnological inventions for patent scope interpretation inter_lawyer. Lex -scripta.p. ¿.available at;

http://www.inter-lawyer.com/lex-e-script/articles/patent-scope.htm

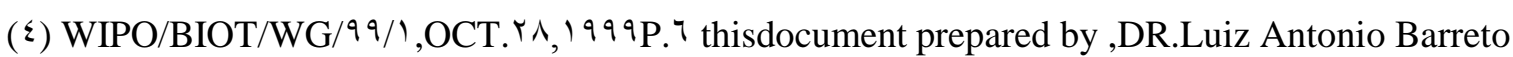
de Castro.MR. Jeffery Kushan Attorny-at- law,DR..Zaleha Mohd.Myain,prof.Joseph Strauss. 
العديد من براءات الاختراع في مجال التكنولوجيا الحيوية،(') وإن ظهر أثر لجماعات الضغط القوى (الذي مارسه الرأي العام متمثناً في جماعة فكر أمريكية) على مكتب براءة الاختراع الأمربكى، إلا أنه كان أثراً مؤقتاً، حيث رفض مكتب البراءة في البدايـة كل الطلبات الخاصـة ببراءة اختراع للحيوانات التي تم تعديل صفاتها وراثياً، لكنه ما برح أن عاد إلى سيرته الأولى، فأصدر العديد من البراءات(ب).

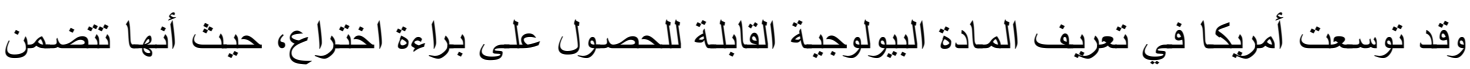
الحيوانـات والنباتـات أو طريقـة إنتاجهـا وأيضـاً (DNA,RNA.AMINO ACIDO A والخليـة وأجزاءهـا والبروتين .......الخ، (†). ولم تكتف الولايـات المتحدة الأمريكيـة بالتوسع في تعريف المـادة البيولوجيـة القابلـة للحصـول على براءة اختراع، بل منحت أكثر من نوع من الحماية للاختراعات الناتجة عن التكنولوجيا الحيوية، حيث تنم الحماية إما ببراءة اختراع أو عن طريق الأسرار التجارية (Trade Secret) أو عن طريق براءة المنفعة ( Utility

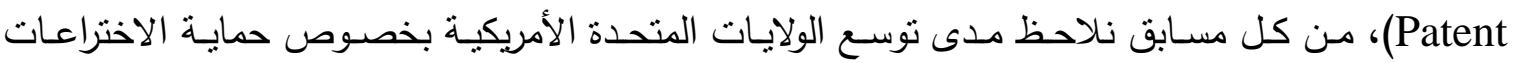
الناتجـة عن التكنولوجيا الحيوية، وهو ما يخدم مصالحها كما عملت جاهدة على إنفاذ رؤيتها؛ ولذا سعت جاهدة لإلزام الدول بالسير في ركابها وظهر ذلك من خلال الاتفاقيات الثنائية والتهديد بالعقوبات التجارية، سواء الحرمان من ميزة أم اتخاذ إجراءات انتقامية. ويمكن أخذ المكسيك كمثال على ذلك: حيث ألزمت المكسيك بتنبي معايير حماية قوية لكي تتضم إلى مئى اتفاقية لنافتا (NAFTA) وأجرت تعديلات كبيرة على قانونها الخاص بحماية حقوق الملكية الفكرية كثرط للانضمام إلى اتفاقية (NAFTA) بما يشبع رغبة الولايات المتحدة الأمريكية بخصوص تقوية وتوسيع الحماية

وعرف قانون الملكية الصناعية المكسيكي الاختراع:" بأنه كل إبداع إنساني يسمح بنقل المعلومات عن

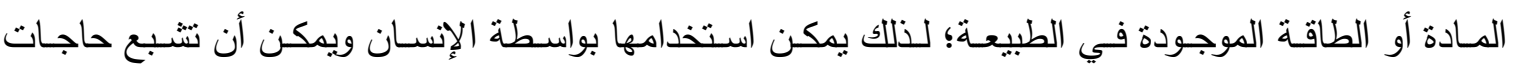

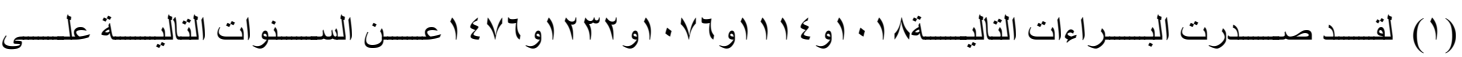

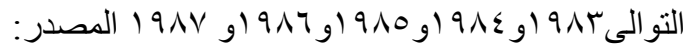

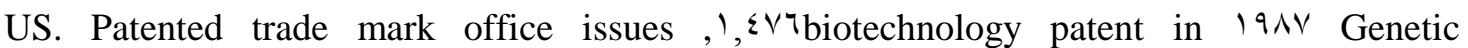
Engineering news $\wedge(r): r^{\circ}$.march 1974 , note in $19 \wedge \vee$ alone the U.S.patent and trade mark office (PTO)issued I, \& $\vee T$ biot.patent up from $1, Y r T$ in 1917 and in 1911

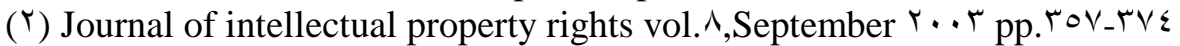

أيضاً راجع ألن جالوش مرجع سابق ص •

( $\ulcorner$ ) Christine C. Vito,ph.D \& Jennifer A. Camacho., Taka global view of life sciences company's patent protection my differ in different countries available at: http://www.tht.com/pubs/searchmatchpub.asp .......more specifically patent can be obtained for :DNA, protein, amino acid ,pure cultures of microorganisms , any bodies and viruses and transgenic plant and animal available at:

http://www.cbdn.ca/englisg/discover/patent.html

(乏) Biotechnology information advocacy and Business support, can living things be patented (in the chakarabarty decision the supreme court stated that anything.under the sun that is make by the hand of man is patentable subject matter) available at: http://www.bio.org/ip/primer/livingthing.asp 
محددة"(') وحدد هذا القانون ما هو غير قابل للحصول على براءة اختراع، حيث إن متطلبات القابلية للحصول

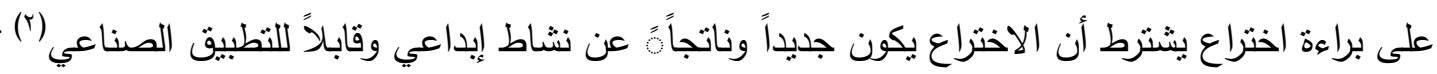
ولقد بين القانون المكسيكي أن كل الاختراعات تكون قابلة للحصول على براءة الاختراع إذا لم تكن مستثناة، لأن القانون حدد اسنتاءات من البراءة على سبيل الحصر وهى: (1) الطرق البيولوجية الجوهرية لإنتاج أو إعادة إنتاج أو تكاثر النبات أو الحيوان. (Y) المادة البيولوجية والوراثية الموجودة في الطبيعة. (r)

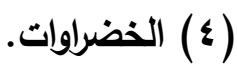

\section{(0) الجسم البشرى والأجزاء الحية التي يتضمنهاب(") .}

ولكن رغبة من المكسيك في الانضمام إلى اتفاقية التجارة الحرة لأمريكا الثمالية(؛) أوجب عليها أن تقوى الحماية بتعديلها أحكام براءة الاختراع وحق المؤلف والعلامات التجاريـة والأسرار التجارية، وذلك حتى تفي المكسيك بمطالب NAFTA التي تتوافق مع الاتفاقيات الدولية لحمايـة حقوق الملكية الفكرية، بل تزيد من معدل الحماية ولذا صدر قانون المكسيك لكي يفي بهذه الالنزامات(ه) ثانياً: الاتجاه الأورويجي: معلئ ولان لقد كان الاتجاه السابق هو عدم حماية الكائنات الدقيقة ذاتها، حيث كانت أغلب قوانين براءة الاختراع في الدول الأوروبيـة لم تعالج مسألة قابلية الكائنات الدقيقة للحصول على براءة اختراع، وإنما منحت الحمايـة لطريقة استخدام الكائنات الدقيقة وكذللك المنتجات الصـادرة عن استخدامها، وكان السبب في ذلك أن حماية الكائنات الدقيقة ذاتها يتعـارض مـع المبادئ التقليدية الراسخة التي يقوم عليها نظـام براءة الاختراع، والتى

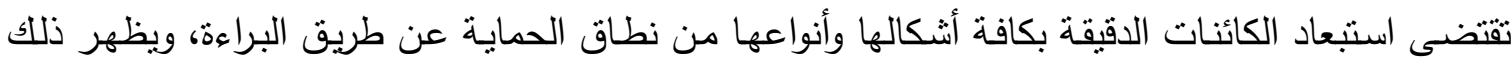
من موقف القضاء الفرنسي، حيث إن الأحكام القضائية في فرنسا قررت حماية الطرق البيولوجية الدقيقة مثل

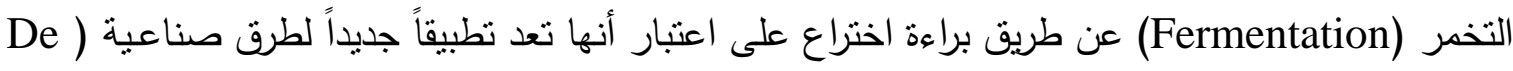
.(`)(nouvelles méthodesd'application industriels

(1) Euripi supra note 1 ro, article 10.

(Y) Article 17.

( $($ ) LPI,supra note $9 \vee$,article 17

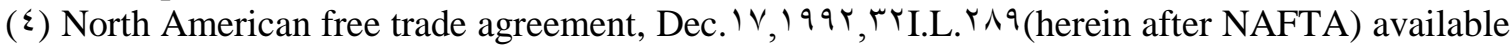
at: http://www.utexas.edu/law/Journal/tiplj/volums/vol I 7 / ss r/tray.html

(०) Ley de la provided industrial D.O,el ${ }^{\Upsilon}$ de agosto.de $199 \leq$ article 1 (herein after PI)

( 7 Christain lestan C. exclusion de brevetabilite. Juris callers. fasc. 10. no $\mathrm{V}$, trib.eiv.seine 9

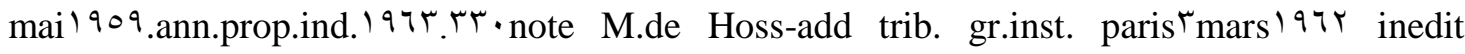
et ${ }^{\top}$ mars 1970 :rev.del, I.n.Pi. 1970 .BJ.Vo ,More information see, http://genet.univ-tours.fr/gen ..rr../gen ..rr.._II_contexte.htm

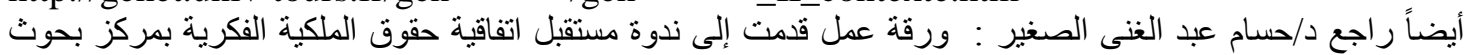

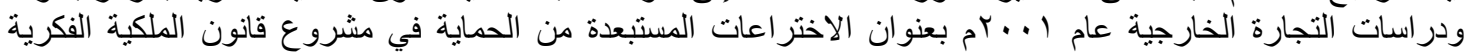
ص. 
ولكن هذا الاتجاه الأوروبي لم يستمر على هذا الحال فلقد تلفح عباءة أخرى خاصة بعد صدور الأحكام

القضائية في أمريكا بمنح براءة اختراع للكائنات الدقيقة ذاتها (').

وإن كان أهمها الحكم القضائي الصـادر في قضية شاكرابارتى، حيث يعد نقطة التحول وظهر ذلك أيضاً

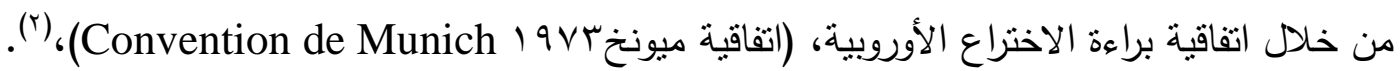
حيث أنها تتاولت موضوع حماية الاختراعات الناتجة عن التكنولوجيا الحيوية فقد نصت المادة (rه) من الاتفاقية على: أنه لا تمنح براءات الاختراع الأوروبية عن (ب) أصناف النباتات أو أجناس الحيوانات وكذللك الطرق البيولوجية في معظمها لإنتاج النباتات والحيوانات، ولا يسرى هذا الحكم على الطرق البيولوجية الدقيقة والمنتجات التي يتم الحصول عليها باستخدام هذه الطرق. وقد نقلت الدول الأوروبيـة في تشـريعاتها أحكام هذه الاتفاقية، ويتضـح ذلك من قانون براءة الاختراع الفرنسي، حيث تم تعديل المادة (V) من القانون الفرنسي الصـادر 971 ام حيث قررت الفقرة (ج) من المادة المذكورة بأن الاستثناء يتعلق بأجناس الحيوانات والطرق البيولوجية في معظمها والمنتجات التي ينم الحصول

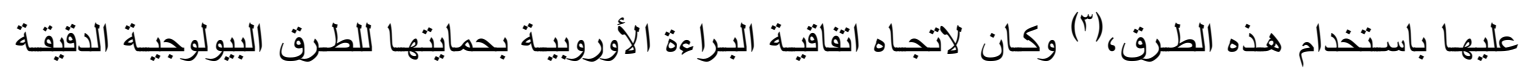
والمنتجات التي يتم الحصول عليها باستخدام هذه الطرق دون الكائنات الدقيقة ذاتها، أثر على مكتب البراءة

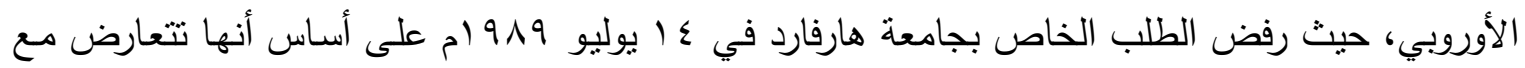

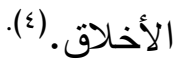

كما أوضح قسم الفحص في قراره أن واضعي الاتفاقية الأوروبية قد أرادوا استبعاد حماية الحيوانات بصفة

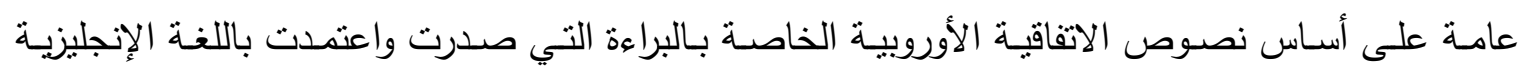

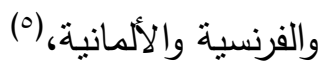

ولكن دائرة الطعن استغلت تتوع العبارات المستخدمة في كل لغة للتوصل إلى الحل المخالف بإعلانها أن

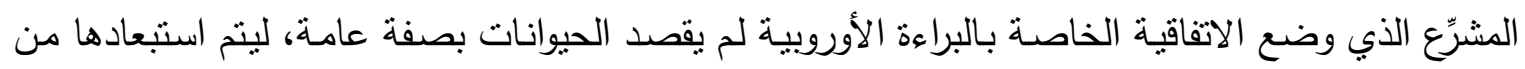

(1) patenting and Biotechnology available at http://www.jic.bbsrc.uk/exhibitions/biofuture/patenting.htm

( $\checkmark$ ) convention de Munich sur la deliverance brevet Europeans du० October 19vr (the European patent convention) art. ${ }^{\circ}$ (b) es variétés végétales ou les races animales ainsi que les procédés essentiellement biologiques d'obtention de végétaux ou d'animaux, cette disposition ne s'appliquant pas aux procédés microbiologiques et aux produits obtenus par ces procédés.

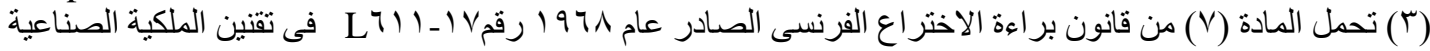

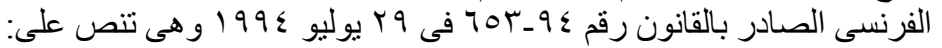

Ne sont pas brevetables: ....... (c) les races animals ainsi que les procedes essentillement biologiques $d$ obtention de vegetaux ou $d$ animaux cette disposition ne $\mathrm{s}$ appliquant pas aux proceds micro-biologiques et aux produits obtenus par ces procedes

(๕) DR. Mana Ashiya, Harvard medical school center for international development at Harvard university (CID) intellectual property rights in biotechnology available at :

http://www.cid.harvard.edu/cidbiotech/bioconf/textr.htm

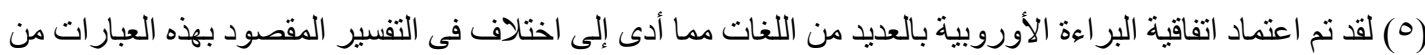

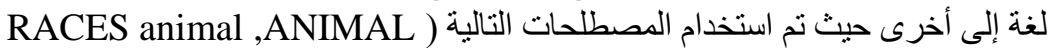

(VARIETIES,TIERARTEN بنفس الترتيب المبين الإنجليزية و الفرنسية و الألمانية 
أن تكون مادة بحث قابلة للحصول على براءة اختراع، ولكن في النهاية بعد أن تم إعادة ملف الدعوى إلى ألى قسم الفحص مرة أخرى انتهى إلى التأكيد على أن الثدييات بسبب مرتبتها في علم قوانين التصنيف تصلح فئح لأن تكون مادة للبراءة.

ويمكن لنـا أن نسـتنتج أن: الطلبات المتعلقة بالحيوانـات التي هي على نفس مرتبـة الثدييات مثنل الحشرات والعصافير والأسماك، تصلح لأن تكون مادة للبراءة ويعد قرار مكتب البراءة الأوروبي هذا غايـة في الأهمية، إذ إنه فتح الطريق أمام حماية الحيوانات التي يتم تعديل صفاتها الوراثية بشرط توافر كل المعايير

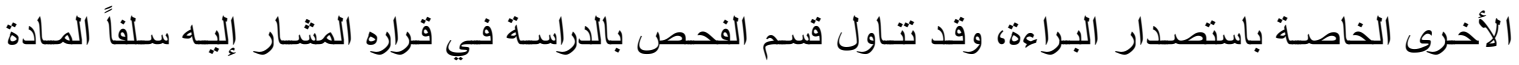
(به(أ))، (') من اتفاقية البراءة الأوروبية والمتعلقة بعدم إصدار براءة يكون منحها أو تتفيذها مناقضاً للنظام

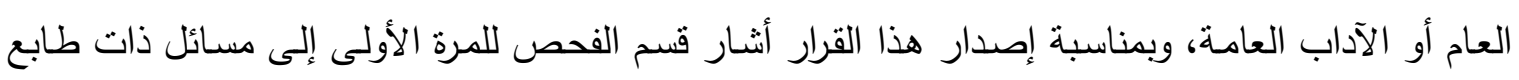
أخلاقي، (ץ) تتطبق على استحقاق الحيوانات للبراءة التي تتاولتها المادة (بهأ(أ)) من الاتفاقية.

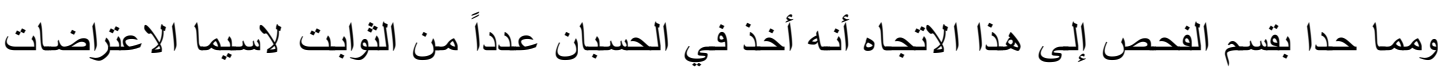
التي ظهرت في الولايـات المتحدة الأمريكيـة بعد منح البراءة لجامعة هارفارد، وفى نفس الاتجاه قام قسم الفحص بدراسـة بعض المشـاكل النوعيـة الخاصـة بهذا الموضـوع مثل إمكانيـة استخدام نمـاذج غير حيوانيـة والاختراع الهادف إلى خلق أورام على حيوانات معملية وكذللك الحيوانات التي يتم اعتبارها كأثباء ومخاطر انتشـار الورم في طبيعـة الحيوانـات التي يتن تعديل صـفاتها الوراثيـة، وفـى أعقاب هذا التقكير والتذكير

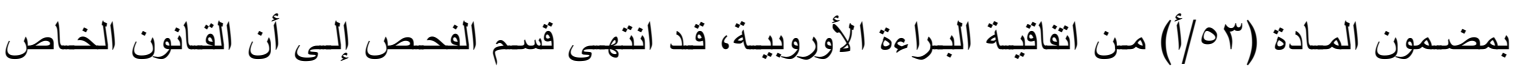
بالبراءات لا يمثل الأداة القانونيـة المناسبة لتسوية المشاكل والمخاطر سالفة الذكر ، بحيث لا يمكن للمادة

$$
\text { (r/أ) أن تكون أساساً لرفض طلب البراءة، (r). }
$$

ولم يحظ هذا الموقف بتقدير دائرة الطعن التي نظرت الملف وأكدت عكس ذلك لأن من واجب قسم

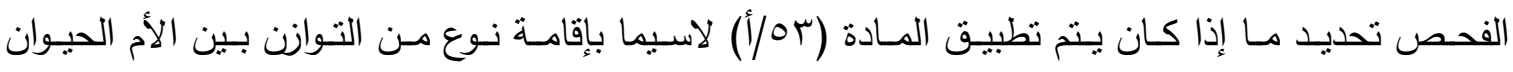

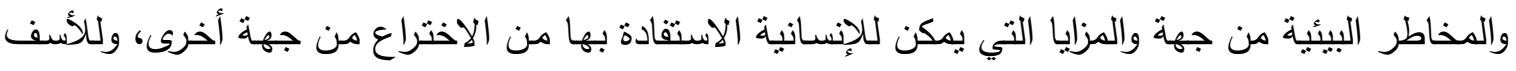

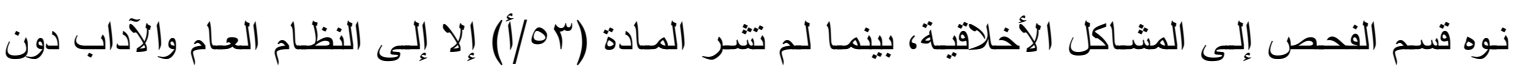

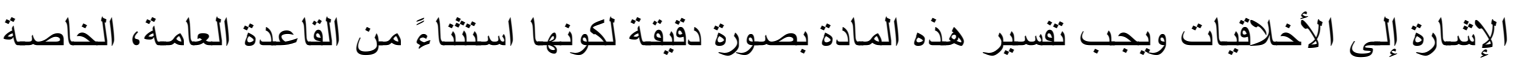

(1) Article or (a) of the EPC: European patent shall not be granted in respect of: (a) inventions the publication or exploitation of which would be contrary to order public, or morality provided that the exploitation shall note be deemed to be so contrary merely because it is prohibited by law or all of contracting states :

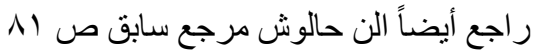

( $($ ) Harvard /once-muse ( $199 \cdot)$ EPOR $0 \cdot 1$, plant genetic systems/Glutamine syntheses inhibitors (TrOT/9T) 1990 EPOR rovand Howard Florey relaxin(1990) EPOR०々). In each case the arguments relating to morality was dismissed by the relevant examining board of the European patent office.

( $)$ An OECD document summarizing the various position on intellectual property practices in the field biotechnology available at: http://www.oecd.org/ech/seatle/docs/biotech.pdf 
باستصدار البراءة، وهذا القرار لدائرة الطعن ضـاعف اللبس على قسم الفحص ولم يستطع سوى أن يستتتج أن كفة الميزان تميل نحو المزايا لكون السرطان هو المرض الذي يشير إليه الاختراع(').

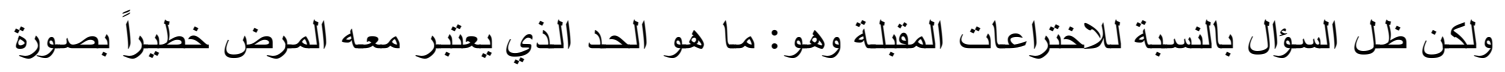
كافية حتى ترجح كافة المزايا التي تستقيد بها البشرية من الآم الحيوان، لقد أجاب المكتب الأوروبي للبراءات على هذا السؤال، في حالة الحيوان الذي يتم تعديل جيناته المفيدة في نبت الثعر ففي هذه الحالة لم يعتبر الصلع الذي تصاحبه أحياناً المشاكل النفسية كافياً لتميل كفة الميزان ناحية المزايا التي تستقيد منها البشرية؛ ولذا تم رفض الطلب الخاص بالحصـول على بـراءة اختراع، ولكن في النهايـة يمكن القول بأنـه انتصـر المنادون بإصدار براءة في مجال التكنولوجيا الحيوية(؟). ورغم ذلك لم يتم التوافق بين دول الاتحاد الأوروبي على النحو التام بخصوص الاختراعات الناتجة عن التكنولوجيا الحيوية؛؛ ويظهر ذلك من موقف كندا من البراءة في هذا المجال، فإنه وإن كانت غالبية الدول الأوروبيـة سـارت في الركب الأمريكي بعد أن كانت متأخرة عن الوضعية الأمريكيـة في مجال اختراعات

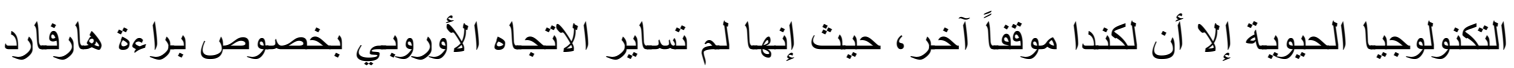
في صورة الفأر المهيأ للإصابة بالسرطان للأغراض البحثية(؟). وترجـع أحداث هذه القضية إلى عـام بو9 ام عندما رفض مفوض البراءات الكندي منح بـراءة الاختراع

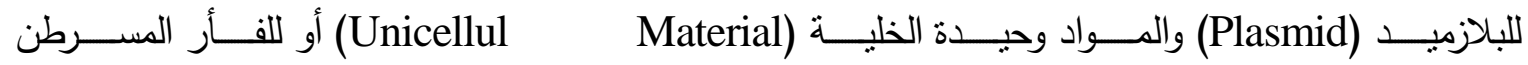
ولكن هذا القرار لم يناسب أصـحاب البراءة وتم استئناف قرار مفوض البراءات أمسام المحكمة الفيدرالية التي وصلت إلى نفس نتيجة قرار مفوض البراءات وذلك لأسباب التالية:

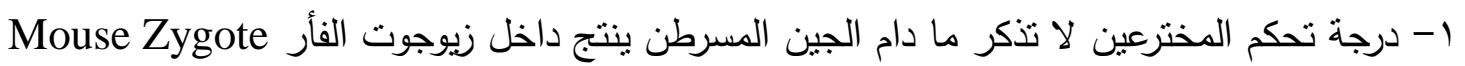
ץ- كما أن التوصل إلى الفأر المسرطن نتيجة للاتحاد وثيق الصلة بين التدخل البشرى وقوانين الطبيعة؛ ولذا فالنتيجة ليست من الإبداع الإنساني.

- أيضـاً الفأر المسرطن لا يمكن أن يعيد إنتاج نفسـه (يتكاثر)؛ ولذلك فالاختراع لا يمكن أن يكون قابلاً للتكاثر ، بالإضـافة إلى أن الكائنات الراقيـة (Higher) أو متعددة الخلايـا (Multicellular) تمثنل أثـكال حياة غير قابلة للحصول على براءة اختراع(أ).

(1) EP $(797 \vee \times B$ ।: the subject of the claims of this patent is the universally known Harvard cancer mouse. The patent claims of the respective European patent application are published in EPI $794 V Y A)$

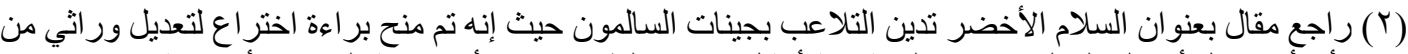

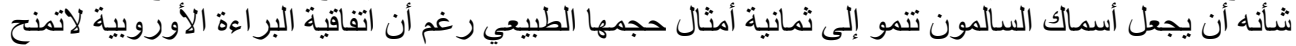

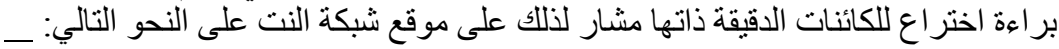
http://www.news.masrawy.com/masrawynews.htm

( $r) D R$. William lies.Higher life-forms before the law.the Supreme Court of Canada`s recent decision patenting of the (Harvard Mouse) raises issues that go far beyond the laws simple categories of life forms. Available at: http://www.leiss.ca/chronicles/ $9 \cdot$ lottawa,onk $n^{\top} n^{\circ}{ }^{\circ}$ canada.htm

( $\varepsilon$ ) David Gambrill .law times.court allows patent on Harvard mouse Decision paves the way for patenting all life forms except Humans available at: http://www.canadalawbook.ca/headlines/headlines ${ }^{\circ}$ r-arc.htm 
ولذا صدر قرار المحكمة الفيدرالية الكندية مؤيداً لقرار سابق من قبل مفوض البراءات برفض براءة اختراع

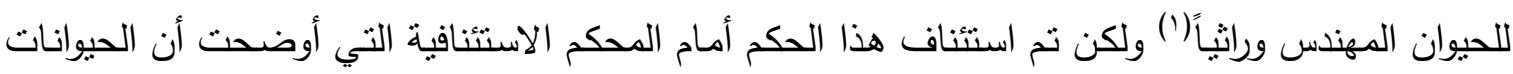
كما في فأر هارفارد ليس موضوعاً قابلاً للحصول على براءة اختراع، وقد توصلت المحكمة إلى هذا القرار بناء على تعريف الاختراع في القسم الثاني من قانون البراءة الكندي، (؟) حيث عرف الاختراع بأنه: أي فن جديد ومفيد (طرق. آلة. تصنيع أو نوليف مادة)(r). ورغم أن قانون البراءة الأمريكي يستخدم نفس الكلمات الموجودة في قانون براءة الاختراع الكندي، لكنهـ

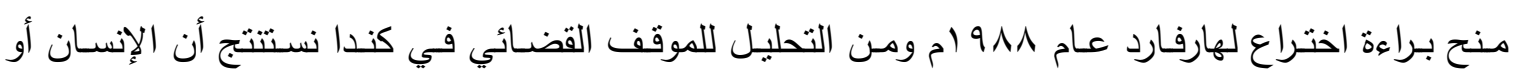
الحيوان مثل فأر هارفارد لا يقع في إطار تعريف الاختراع حيث إن المحكمة قررت أن هذا الفأر ليس مادة

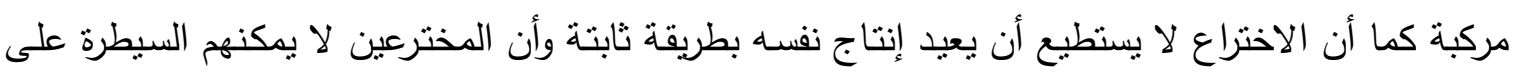

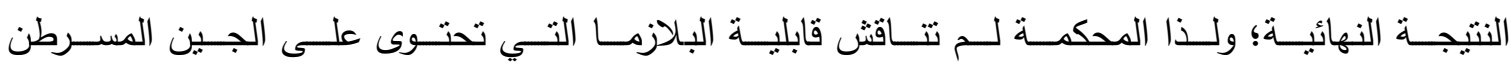

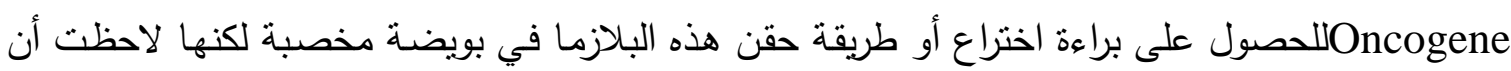
العديد مـن الخطوات الباقيـة لإنجـاز المنتـج النهائي نركت لقوانين الطبيعـة على النحو المحدد وبالثـكل المعروف في علم الوراثة لقانون مندل، حيث فرضت قوانين الوراثة النتيجة النهائية التي جاءت للمزئ بين العمل الإنساني وقوانين الطبيعة، وهذا الاتجاه يتفق مع الوضع السابق بخصوص (حبة الصويا)(؛)..

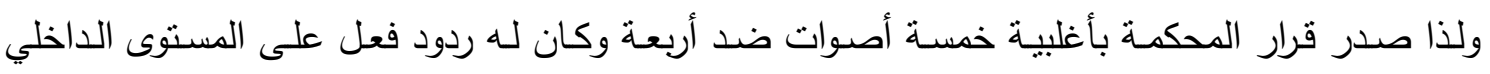
والخارجي، حيث إن المحكمة برفضـها براءة اختراع هارفارد حالت المحكمة دون انضمام كندا لمسار أمريكا

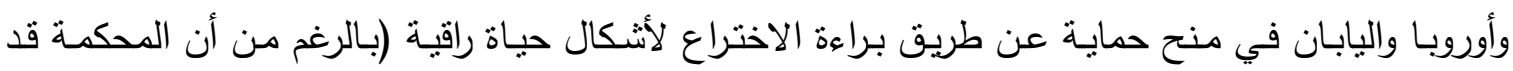

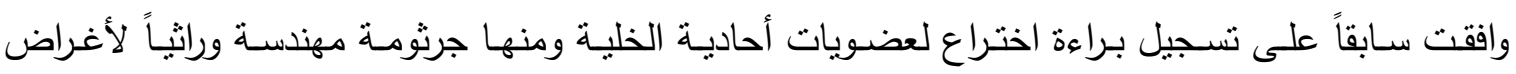
صناعية) ولقد أثتت جماعات بيئية على قرار المحكمة الكندية، حيث أوضحت منظمة السلام الأخضر أن هذا القرار انتصار للحياة، ويجب ألا يطرأ عليه أي تعديل؛(ه). وعلى الجانب الآخر قرر أحد محامى المدعى (هارفارد) أن السماح بتسجيل براءة اختراع للفأر المعدل

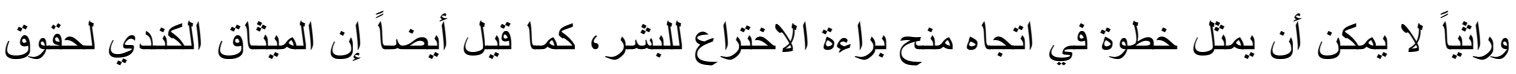

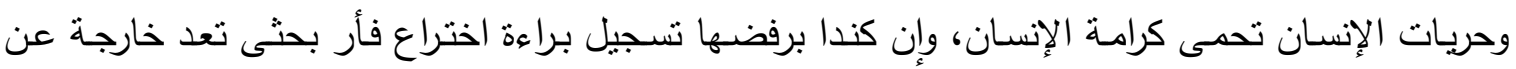

( 1 ) Canada rejects patents on higher life forms meaning Canada supreme court rules out patents on higher life forms Limli Ching reports on this landmark decision and its wider implications. The institute of science in society, London NW ' OXR: available in the isis members site ...... http://www.i-sis.org.uk/crohlf.php

$(r)$ Thomas W. Baily September 1997 Newsletter. Patenting life forms in Canada :available at: http://www.patentable.com/newsletters/sep 9 \ news.html

( $r$ ) section $r$ of the patent act's $1 \wedge r 9$ says an invention consists of any new and useful art process, machine, manufacture or composition of matter:

$(\varepsilon)$ the earlier case of pioneer Hi-Berd Lted. Wherein it was determined that novel soybean variety. Produced by natural cross-breeding strategy was unpatentable. On the basis of the element of chance $==$ involved in reproducing the variety. Further information see, Gale Baker,box ${ }^{r} \leqslant r$, station D, Ottawa Ontario, $k^{\top} p^{\top} n .{ }^{q}$ available at http://www.kirbyeades.com.

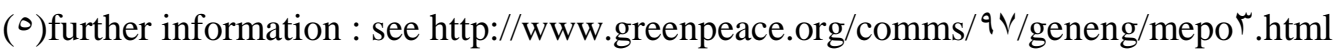


شـركائها التجاريين، كمـا أن بعض العلمـاء الكنديين علقوا على قرار المحكـة بأنـه يجب على البرلمـان أن يعدل قانون براءة الاختراع ليعطي براءة اختراع لكل أشكال الحياة الراقية، عدا البشر (').

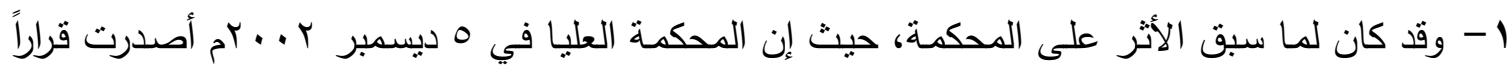
في قضية هارفارد إعتبر فيه مفوض البراءات أن الفأر المسرطن قابل للحصول على براءة اختراع(؟) بل

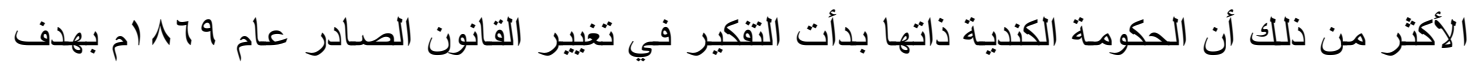
جعله بشتنمل على القضـايا المتعلقـة بالتكنولوجيا الحيويـة؛ وإذا كانت الولايـات المتحدة الأمريكيـة تتزعم الدول التي تؤيد حمايـة اختراعـات التكنولوجيـا الحيويـة عن طريـق بـراءة الاختراع دفاعـاً عن مصـالح شركاتها الصناعية صساحبة الريادة في مجال التكنولوجيا الحيوية، فإن الوضـع في الاتحاد الأوروبي لم لم يكن على نفس خط الولايـات المتحدة الأمريكية، حيث ظهر فيه الخـلاف وعدم التتاسق بين تشريعات

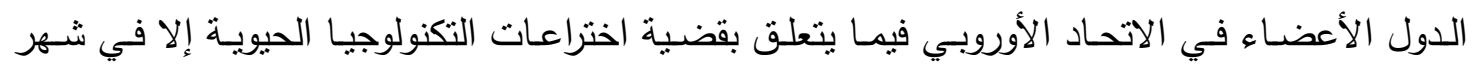

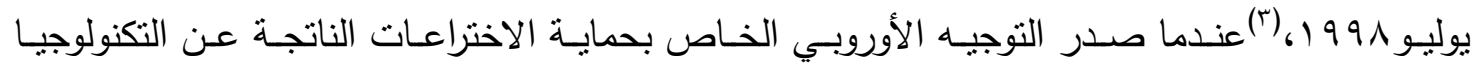
Directive on Legal Protection of Biotechnological Inventions الاختراعات الناتجة عن التكنولوجيا الحيوية في كافة بلدان الاتحاد الأوروبي(؛).

( 1 ) in an opinion piece about the Supreme Court's decision Ottawa citizen, $\backslash \leqslant$ Dec. $r \cdots r$ B $\vee$ university of Ottawa law professor. Daniel Gervais she says that parliament must amended the patent act to cover all higher life forms except human, further information: see http://www.greenpeace.org/comms/9v/geneng/mepor ${ }^{\top}$.html ولذا قيل إنه يجب أن يكون هناك تعريفاً لأشكال الحياة الراقية التى يجب أن تتضمن أى حيو انات ويجب أن يتم وضع أحكام

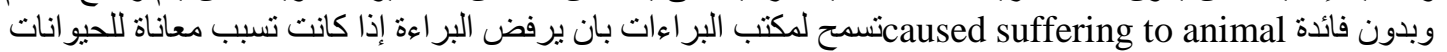
جوهرية للبشر أو الحيو انات

$(r)$ Higher life forms and the patent act Feb. $r \leqslant, r \ldots r$ available at http://www.cbac-cccb.ca/epic/internet/incbac-cccd.nsf/en/ah ..r V Ve.html.

$(\ulcorner)$ The European parliament and council therefore adopted directive $9 \wedge / \Sigma$ \&/EC.on 7 July 1991 to a chive the harmonization of these differences of legal protection for biotechnological inventions and particular to ensure their the directive into domestic law by appropriate legal and administrative regulation.

(๕) Lanjude and Mathew Frankel. European parliament approves biotech directive, law journal extra Sep. /oct. 1991 p.r 
ץ - وهذا الاتجاه الذي تمنله الدول المنقدمة والتي تريد من خلاله تعريف الكائنات الدقيقة على نحو واسع إعمالاً للمصالح الذاتية، حتى وصل الأمر في الولايات المتحدة الأمريكية لدرجة أنها أصبحت تمنح براءة اختراع لبعض أجزاء الجسم البشرى منل الدم والبروتين والتسلسل الجيني......الخ مما زاد من معدل منح براءات الاختراع في أمريكا،(') وكما قلنا مسبقاً: أن أوروبا سايرت الولايات المتحدة الأمريكية، ويظهر ذللك من تتاول بعض أحكام التوجيه الأوروبي حيث إن المادة (^) من التوجيه فقرة (I) نصت على: أن الحماية الممنوحة ببراءة اختراع للمادة البيولوجية التي تمتلك خصائص معينة نتيجة للاختراع سوف تمتد إلى أى مادة بيولوجية اشتقت من تلك المادة من خلال التكاثر في شكل متطابق أو متباعد وتمتلك نفس نئس

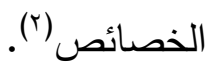
r- فالحماية التي تمنح بواسطة براءة الاختراع للطرق التي تمكن المادة الحيوية من إنتاج خصائص محددة نتيجة للاختراع، سوف تمتذ الحماية إلى المادة الحيوية التي حصل عليها مباشرة من هذه الطريقة وإلى بلى أي مادة حيوية أخرى اثتقت مباثـرة من المادة الحيوية التي تم الحصول عليها من خلال التكاثر أو

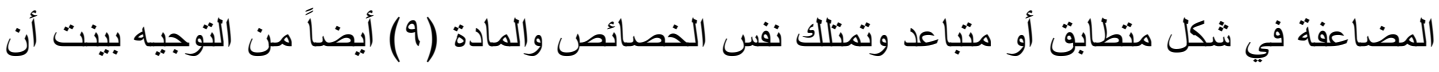
الحماية الممنوحة ببراءة اختراع للمنتج الذي يحتوى أو يتكون من مادة وراثية سوف تمتد الحماية إلى الى

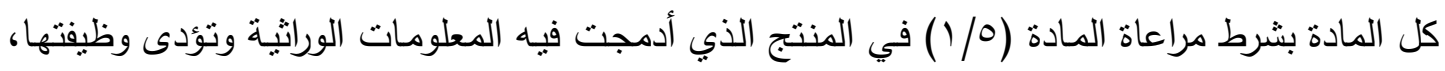

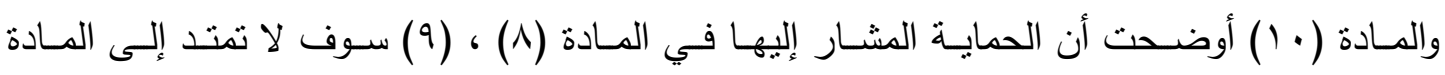
البيولوجية التي حصل عليها من التكاثر أو المضاعفة (Propagation or Multiplication) للمادة البيولوجية التي وضعت للتسويق في إقليم الدولة العضو بواسطة صاحب براءة الاختراع أو بموافقته.

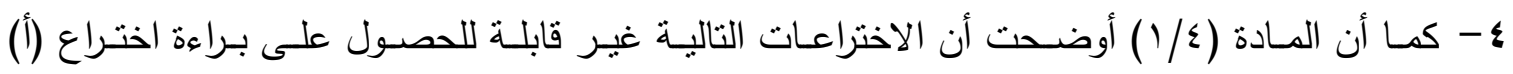
النباتات والأصناف الحيوانية (ب) الطرق البيولوجية الأساسية لإنتاج النباتات والحيوانات أيضاً الفقرة

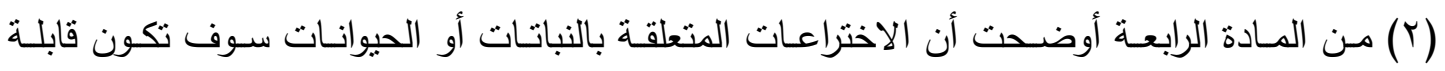

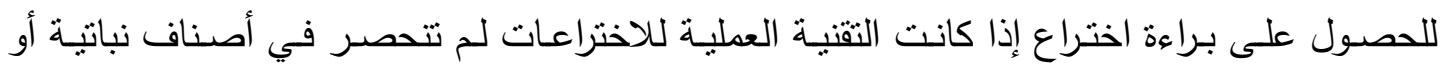
حيوانية معينة، وأيضاً الفقرة (r) من المادة (ع) بينت أن الفقرة ( (/ب) بدون إجحاف بالقابلية للحصول

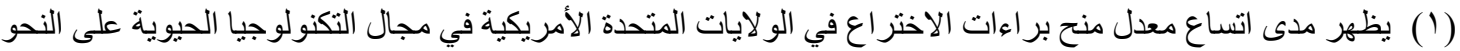

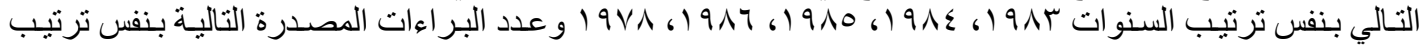

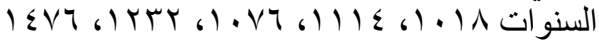

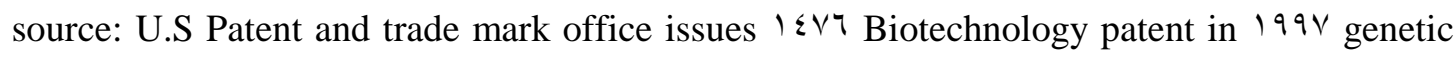
engineering News $\left({ }^{\sim}\right): Y^{\circ}$ march 1974.

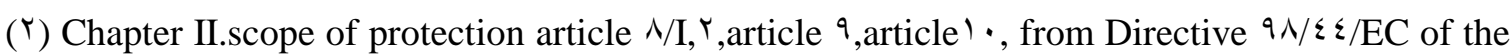
European parliament and of the council of $Y$ July 1991 on the legal protection of Biotechnological invention. 
على براءة اختراع للاختراعات المتعلقة بالطرق البيولوجية الدقيقة أو الطرق الفنية الأخرى أو المنتجات التي نم الحصول عليها بواسطة وسائل مثل هذه الطرق، (1). ه- - المـادة (1/0) أوضــت أن الجسـم الإنسـاني في المراحل المختلفـة مـن تشـكله وتطـوره والاكتثـافات البسيطة لأحد عناصره بتضمن ذلك التسلسل أو التسلسل الجزيئي للجين لا يمكن أن بشكل اختراعات

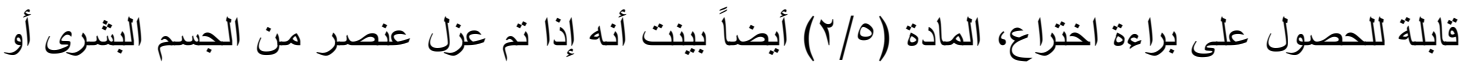

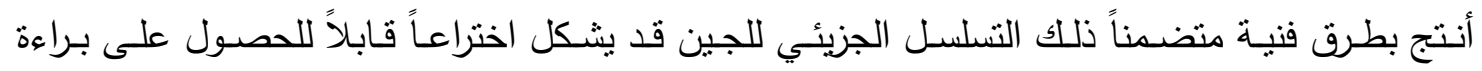
اختراع، حتى إذا كان تركيب ذلك العنصر مطابقاً للعنصـر الطبيعي، المـادة (r/0) أقرت أن التطبيق الصناعي للتسلسـل الجيني أو التسلسـل الجزيئي للجين يجب أن يتم الكشـ عنسه في طلبـات البراءة، والمـادة (1/1) نصـ على أن الاختراعات ستعتبر غير قابلـة للحصـول على براءة إذا كان استخغلالها

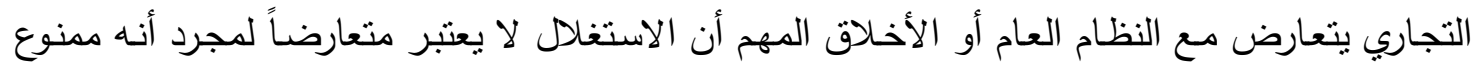
في القـانون أو اللـوائح. كمـا أن المـادة (؟/Y) (على أسـاس الفقـرة ( ()) أوضـحت مـا هـو غيـر قابـل للحصول على براءة اختراع على النحو التالي: (أ) طرق استتساخ البشر (ب) طرق تعديل الخط الجرثومي للهوية الوراثية للبشر (ج) استخدام الجين البشرى للأغراض الصناعية

(د) طرق تعديل الهويـة الوراثية للحيوان التي من المحتمل أن تسبب لهم معاناة بدون أي فائدة طبية

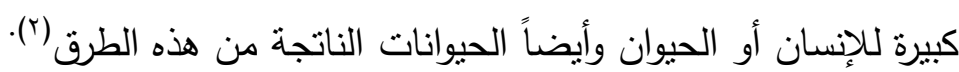

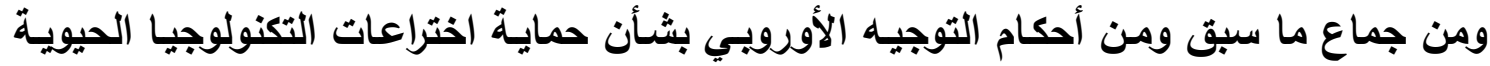
يمكن القول: بأن أحكام التوجيه الأوروبي وسعت من حمايـة اختراعات التكنولوجيا الحيويـة على النحو

الذي يمكن معه التطابق في الكثير من النواحي مع الاتجاه الأمريكي، وإذا كان هذا هو اتجاه الدول المنقدمة التي ترغب في منح تعريف موسـع للكائنات الدقيقة يتعارض مـع التعريف العلمي السليم للكائنات الدقيقة، حيث إن هذا المصطلح يقتصر على الفطريات والطحالب والبكتيريا والكائنات وحيدة الخلية والفيروسات وفقاً للتعريف العلمي (r).

ولـذا يجـب على الـدول الناميـة تبنـى التقسير الضـيق لمفهوم الكائنـات الدقيقة، حيـث إن هـا يحقـق مصالحها.

(1) see: Chapter (1) patentability article $\varepsilon / 1, r, \Gamma$, from directive $9 \wedge / \varepsilon \varepsilon / E C$ of the European parliament and of the council of 1 July $199 \wedge$ on the legal protection of biotechnological inventions further information see: http://www.cptech.org/ip/health/ci/EC.HTML

( $r$ ) see: Chapter ( 1 ) patentability article $0 / \uparrow, r, r$, article $r / 1, r /$ a,b.c.d, from directive $9 \wedge / \varepsilon \varepsilon /$ EC of the European parliament and of the council of $\Upsilon$ July $199 \wedge$ on the legal protection of biotechnological inventions further information see: http://www.cptech.org/ip/health/ci/EC.HTML

( $\left.{ }^{\top}\right)$ Combs Macmillan Dictionary of biotechnology. Macmillan London 1914,p. $19 \wedge$ available at: south center: the trips agreement a guide for the south part IIINO. $Y \varepsilon$ 


\section{المطلب الثاني}

\section{حماية الكائنات الدقيقة في الدول النامية}

الدول النامية كانت بعيدة عن الاتجاه الذي سلكته الدول المتقدمة، حيث إن أغلب تشريعات الدول

النامية لا تتضمن أحكاماً تحمى الكائنات الدقيقة بموجب براءة الاختراع، ولكن هذا الموقف لم يستمر خاصـة

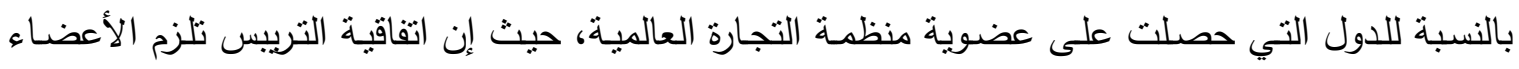

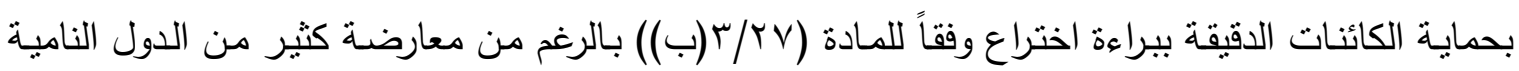

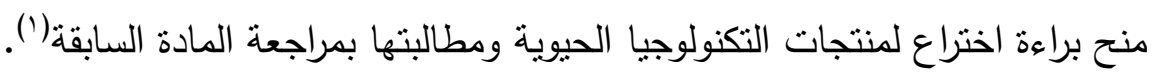
ويمكن تتاول موقف بعض الدول الناميـة من حمايـة الكائنات الدقيقة مـع دراسـة موقف مصر بشيء من التعمق.

\section{الفرع الأول \\ نظرة على تشريعات بعض الدول النامية}

الهند كانت مثل أغلب الدول النامية، لا تولى تشريعاتها حماية للكائنات الدقيقة ببراءة اختراع، فقانون البراءة الهندي الصادر • لو ام كان يسمح ببراءة الطريقة فقط للأغذية والأدوية والكيماويات، ولا يمنح براءة اختراع

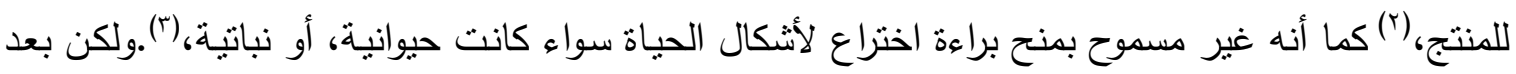
أن وقعت الهند على اتفاقية التربس في يناير 990 ام أصبحت ملزمة بحماية الكائنات الدقيقة؛ ولذا تم تعديل لهيل القانون الهندي 99 ام ليتيح تقديم طلبات براءة اختراع للمنتجات الدوائية والزراعية والكيماوية(؛).

وتم تعديل هذا القانون أيضاً في عام r . . r حيث إن هذا التعديل وسـع من مجال الحماية ببراءة الاختراع ليتضمن الكائنات الدقيقة، (०).

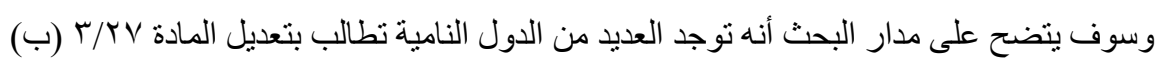

Further information see: Grain ( $r \cdots$ ) for a full Review of trips $r \vee / r(b)$ : an update on where developing countries stand with the push to patent life at WTO. Available: at http://www.Grain.org/publications/reports/tripsfeboo.html

$(\checkmark)$ According to the patent Act, $19 \vee \cdot$ Indian patents Act allows process patents only for food ,medicines, drug and Chemicals. patenting of life forms in not permitted no protection of plant varieties

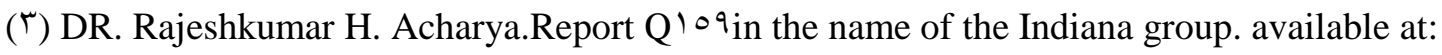
http://www.aippi.org/reports/q 109 -india-e.

(₹) the patents (amendment) Act 1999. the 1999 amendment include provision enabling the filing of world trade organization (WTO) application for product patents in pharmaceutical and agrochemical and granting of exclusive marketing rights(EMR)

$\left({ }^{\circ}\right)$ The patents (amendment) ACT $r \ldots r$ enlarging the scope of patentability to include microorganisms further information see.unitaksreedhara intellectual property rights in the pharma sector - India initiatives business briefing pharmacy $r \ldots r$, available at : http://www.jacobacci.com 


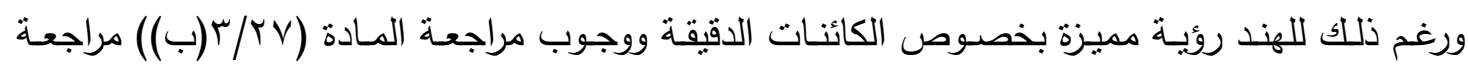
أساسية لأحكام هذه المادة وليس مراجعة هامشية، ولذا تقترح الهند استثناء براءة الاختراع لأشكال الحياة من

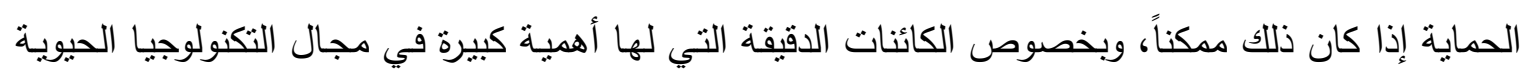

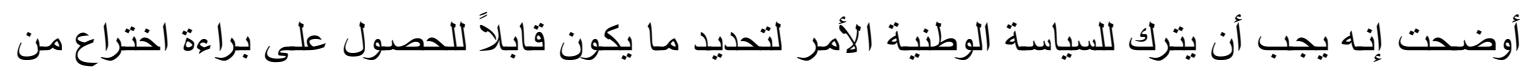
الكائنات الدقيقة على أساس أنه يجب التمييز بين الاكتثافات والاختراعات، حيث إن الأخيرة هي التي يمكن

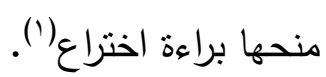

كما يجب توافر معايير القابلية للحصول على براءة الاختراع، حيث إن المادة (I/TV ) بينت أن البراءة

سوف تكون متاحة فقط للاختراعات التي يتوافر لها الجدة Novelty والقابلية للنطبيق الصناعي Capable New.usefulness,non-) Inventive Stepof Industrial Application

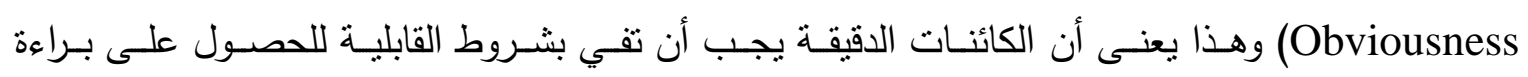
الاختراع، أيضاً الكائنات الدقبقة المشمولة بالحماية هي التي يتم التوصل إليها عن طرق العمل الإنساني أي التعديل الوراثي بالهندسة الوراثية. وقد طرحت الهند سؤالاً بخصـوص مـا إذا كانت المـادة البيولوجيـة مثل الإنزيمـات والكوزميد والبلازميد والجينات قابلة للحصول على براءة اختراع،وكانت الإجابة على ذلك بأن هذه الأشكال غير مؤهلة للحصول

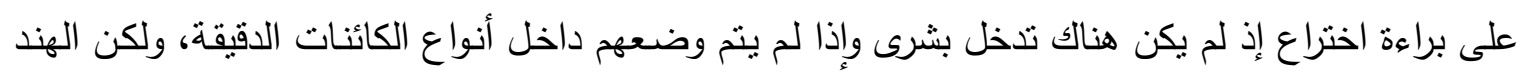

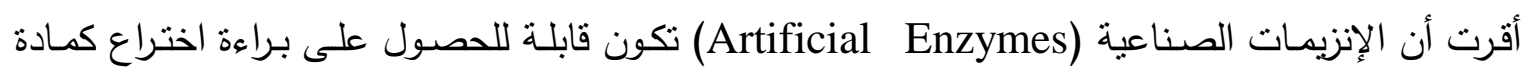

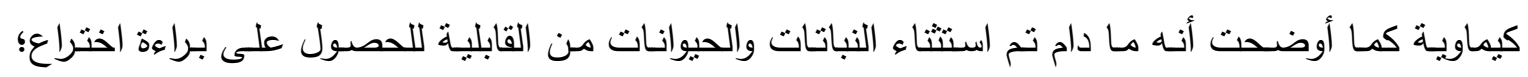
يجب أن يتم استبعاد أجزائهم مـن الحمايـة، لذلك الجين لا يمكن منحسه بـراءة اختراع إلا إذا كـان مؤهلاً

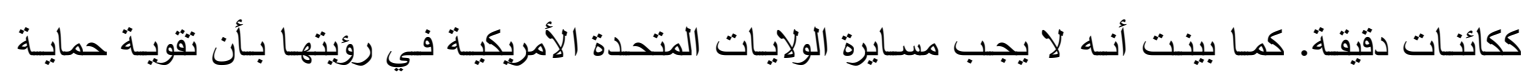
اختراعات التكنولوجيا الحيوية تكون مفيدة(؟).

( (1) لقد قام مكتب البراءات و العلامات التجارية الأمريكى بمنح بر اءة اختر اع لثركة بيرستول ماير لنوع من الكائنات الدقيقة

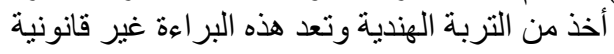
see: patent on Streptomycesviolaceusa micro-organism accessed from The soil in Hyderabad India (patent no. $₹ 99$ Y V ४ ) granted by USPTOin 1999 to BristolMyer would not be avoid patent $(r)$ Someshwar Singh patent on life forms should be re-examined, says India. This paper has been presented at the meeting of the trips council in Geneva, $r V_{0}$ oct. 1999 pp. I-r

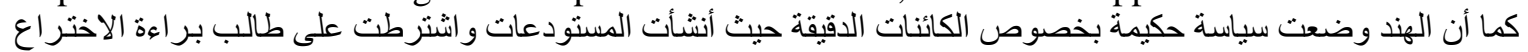

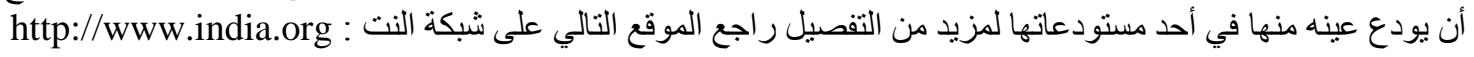


وقد ظهر ذلك عندما انضمت الهند إلى اتفاقية بودابست (Budapest)،('حيث إنها اتبعت سياسـة حكيمة

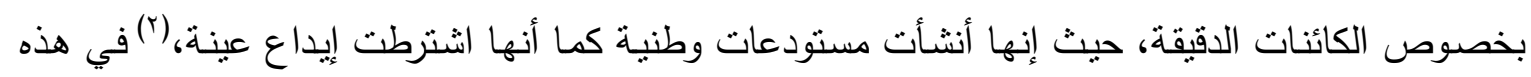

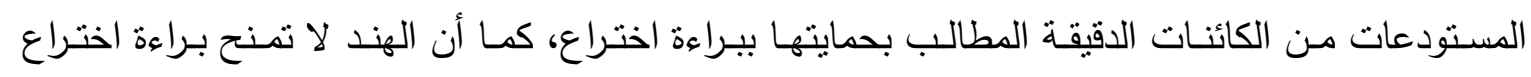

للكائنات الدقيقة إذا كانت ضارة بالصحة.

البرازيل : (البل

يمكن القول بأن موقف البرازيل بخصوص حماية الكائنات الدقيقة يكاد يكون منطابقاً مع الموقف الهندي في الأساس، وقد اتبعت البرازيل سياسة حكيمة في هذا الثأن، حيث إنها قامت بتحديد مصطلح الكائنات الدقيقة

على نحو ضيق يتطابق مع المفهوم العلمي السليم، (َ). كما أنها استبعدت من الحماية جميع الكائنات الحية والأجزاء والعناصر التي نتكون منها المواد البيولوجية الموجودة في الطبيعة أو التي يتم الحصول عليها بعزلها أو القيام بإعادة ترتيبها أي ترتيب التركيب الجيني ولئي

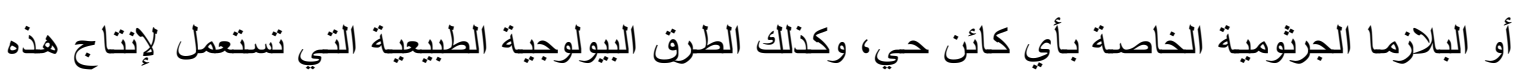
المواد() وقصر الحماية على الكائنات الدقيقة التي عدلت صفاتها بفعل المخترع عن طريق الهندسة الوراثية

دون الكائنات الدقيقة الموجودة في الطبيعة(0).

أفريقيا

لقد كان لأفريقيا روئية واضحة بخصوص حماية الكائنات الدقيقة، وقد ظهر موقف أفريقيا واضحاً من خلال المقترح الذي قدمته المجموعة الأفريقية بثأن هذا الموضوع الى منظمة التجارة العالمية، حيث اعتبرت أن المراجعة يجب أن تخص الجوهر وليس تم تتفيذه في هذا الثـأن، وأوضحت ضرورة امتداد مدة التتفيذ إلى هئ

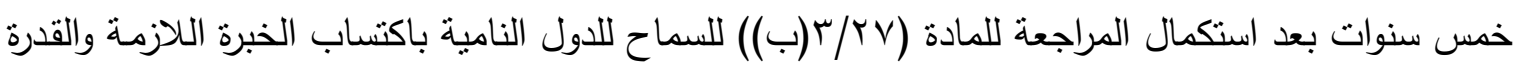

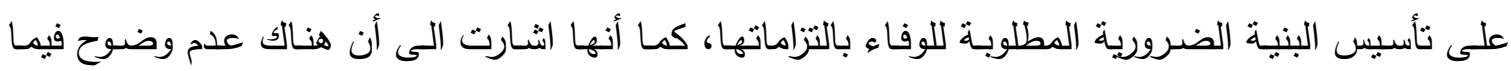
يتعلق بما يمكن أن يكون قابلاً للحصول على براءة اختراع وما لا يمكن، ويرنبط ذلك خصوصاً بـالتمبيز

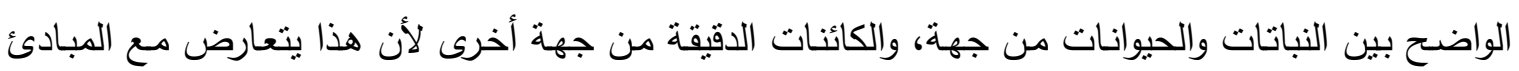

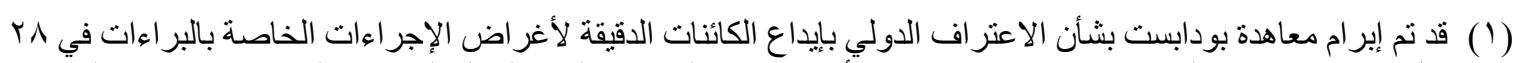

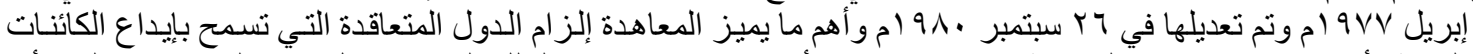

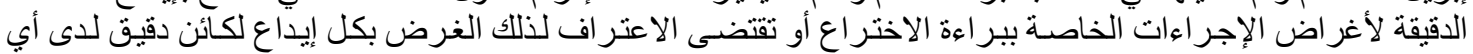

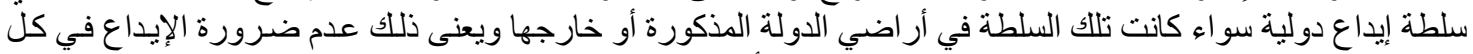

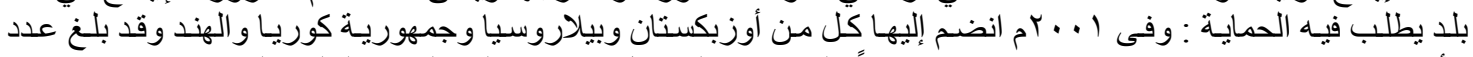

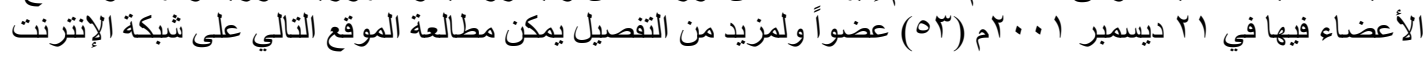
http://www.home.earthlink.net/apronto/treaties/intellec.htm

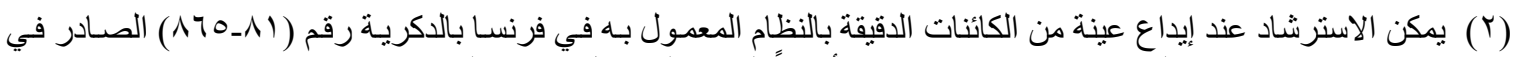

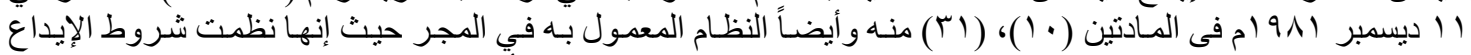

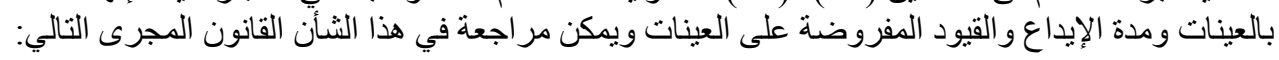

Law No.xxxIII of 1990 on the protection of invention by patents. No.10 / 1917 of sep. وأيضاً المرسوم الصادر عن وزارة الزراعة والأغذية 1V.1917,sectin \& and

( ${ }^{\top}$ ) Combs J.Macmillan Dictionary op.cit p. 191

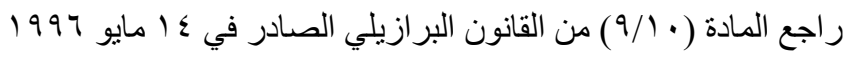

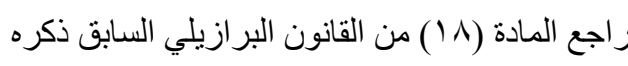


الأولية لمنح براءة الاختراع، حيث إن المواد البيولوجية الموجودة في الطبيعة تمثل اكتشافاً وليس اختراعاً؛ ولذلك يجب استبعاد النباتات والحيوانات والكائنات الدقيقة من الحماية وكافة أثنكال الكائنات الحية الأخرى

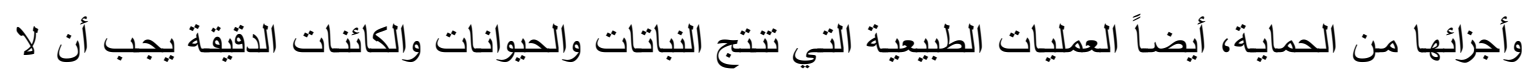

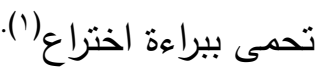

\section{الفرع الثاني}

\section{موقف مصر من حماية الكائنات الاقيقة}

أولا: في ظل القانون القديم رقم ب با لسنة 9 ؟ 9 ام:

عرفت مصر أول تتظيم لحقوق الملكية الصناعية بعد إلغاء نظام الامنياز الأجنبي عام هوبه ام(؟). حينما

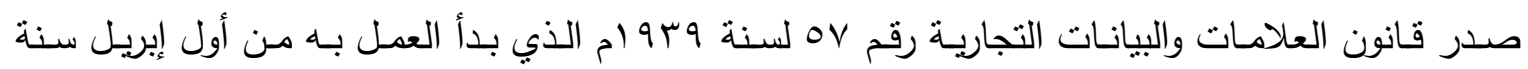
$.0190 \leqslant$

ولكن تجدر الإشارة إلى أنه رغم صدور أول تتظيم لحقوق الملكية الصناعية وبه ام إلا أنه تمت حماية حقوق الملكية الصناعية في مصر قبل ذللك التاريخ؛ فقد كانت المادة (r ( ) من القانون المدني القديم تنتاول ذللك الموضوع، حيث إنها أقرت بحقوق الصانع على ملكية مصنوعاته على حسب القانون المخصص لذلك، كما أن المحاكم المصرية درجت على حماية حقوق الملكية الصناعية قبل صدور تشريعات الملكية الصناعية استتاداً إلى قواعد العدالة والقانون الطبيعي، وأيضاً عن طريق دعوى المنافسة غير المشروعة.

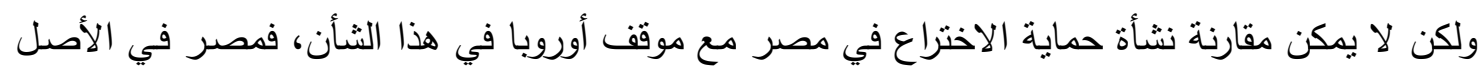

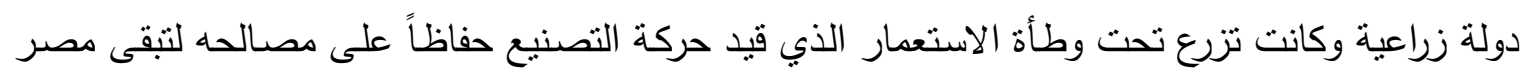

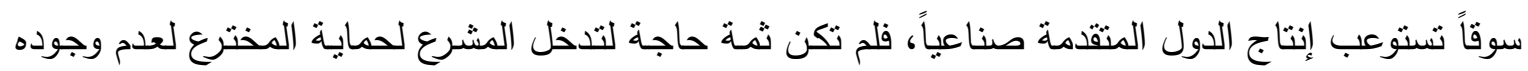
بين المواطنين، علاوة على أن الأجانب كانت مصالحهم مصانة عن طريق القضاء المختلط الذي كان يمكنه في حالة عدم وجود تشريع مصري أن يلجأ إلى المبادئ العامة التي تمثلها قواعد القانون الطبيعي وقواعد الإنصاف.

بـل كانت تســح لائحسة المحساكم المختلطـة اللجوء إلىى التشـريعات الأوروبيـة، خاصـة القانون الفرنسـي

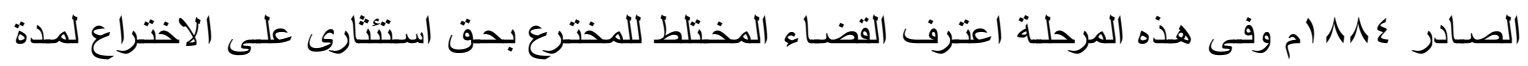

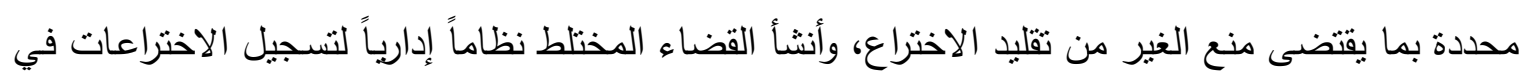
قلم كتاب المحاكم مع جعل أثز التسجيل مقصوراً على إثبات التاريخ دون أن يهنم بتوافر الثروط الموضعية

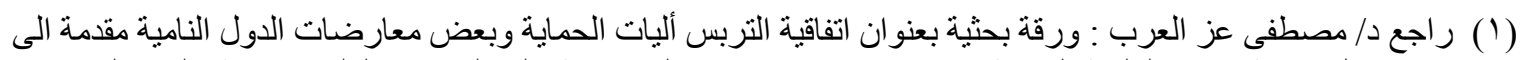

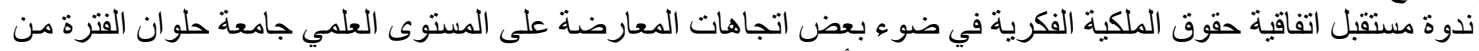

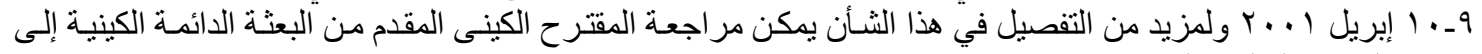

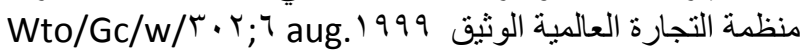


اللازم توافرها لحماية الاختراع، وألزم القضاء المختلط المخترع باستغلال اختراعه في مصر ، وإلا فقد حمايته المترتبة على التسجيل(')

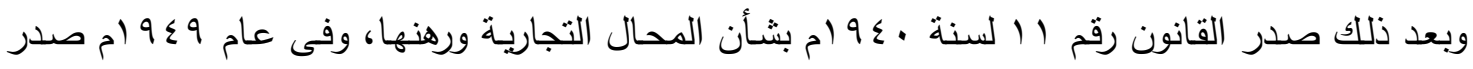

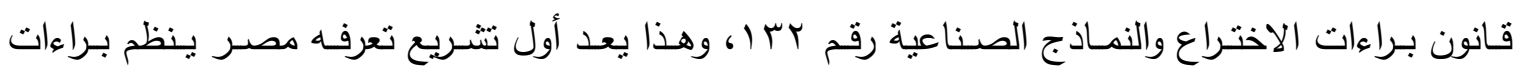
الاختراع والرسوم والنماذج الصناعية وعلى الرغم من أن مصر كان شأنها شأن معظم الدول النامية عربية

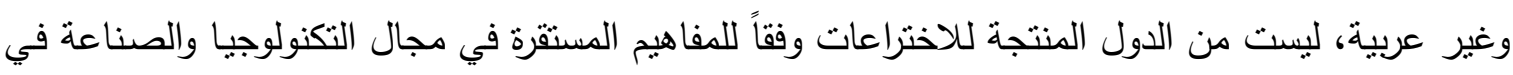

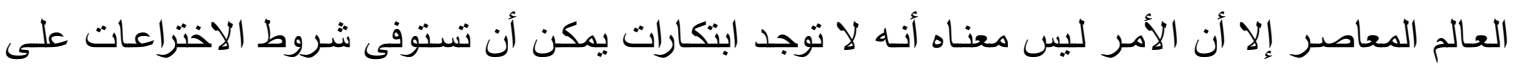

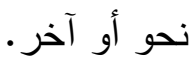
وقد تتاول المشرع في المادة رقم (1) من القانون rr آلسنة 9؟9 ام براءة الاختراع، حيث إنه نص في هذه المـادة على أنـه "تمنح براءة اختراع وفقاً لأحكام هذا القانون عن كل ابتكار جديد وقابل للاستخلال الصناعي، سواء كان متعلقاً بمنتجات صناعية جديدة أم بطرق أو وسائل صناعية مستحدثة أو بنطبيق جديد

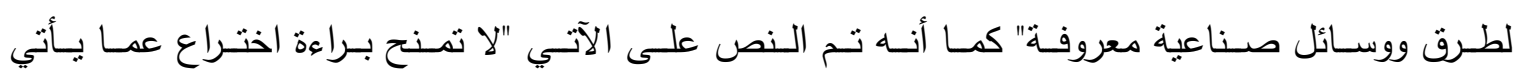

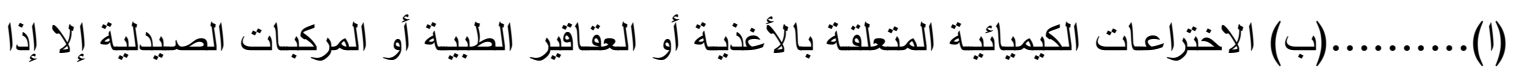
كانت هذه المنتجات تصنع بطرق أو عمليات كيميائية خاصـة، وفى هذه الحالة الأخيرة لا تتصرف البراءة إلى المنتجات ذاتها، بل تتصرف إلى طريقة صنعها". ويذلك نجد أن المشرع المصري: حظر منح براءات اختراع للاختراعات الكيميائية المتعلقة بالعقاقير الطبيـة والأغذيـة، حتى لا يكون إنتاج تلك الأغذيـة والعقاقير الطبيـة خاضـعاً لاحتكار يؤدى إلى استغلال

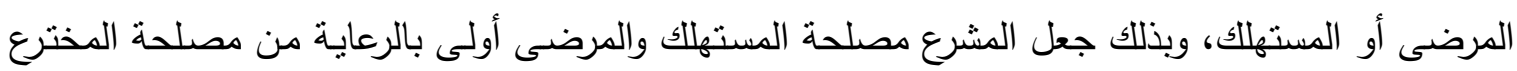

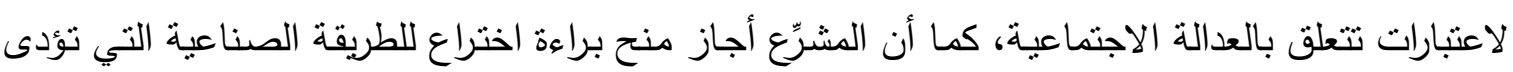
إلى هذه المنتجات(r).

ومن الجدير بالأكر أن المشرّع المصري لم يتتاول الكائنات الدقيقة بالحمايـة شـأنه في ذلك شـأن معظم

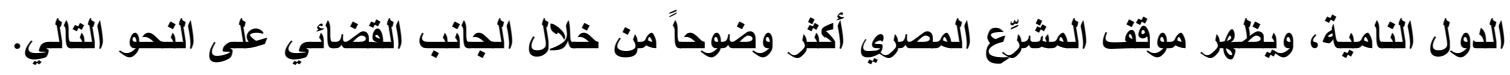
فتوى مجلس الاولة: بشأن مدى قانونية تسجيل طلبات براءات الاختراع التي نطالب بالحماية القانونية لتسجيل السلالات أو البكتيريا أو الفيروس أو الفطر أو اللقاحات أو الأمصال وطرق تحضيرها أو استخدامها في منتجات أخرى، وتخلص وقائع الموضوع حسبما هو ثابت، أنه قد درج العمل بمكتب براءة الاختراع على الى

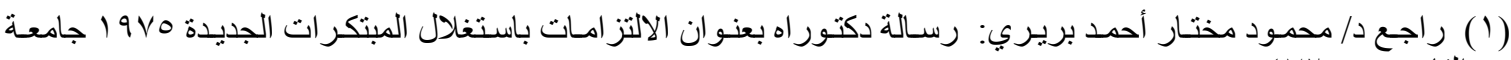
القاهرة ص ع د د

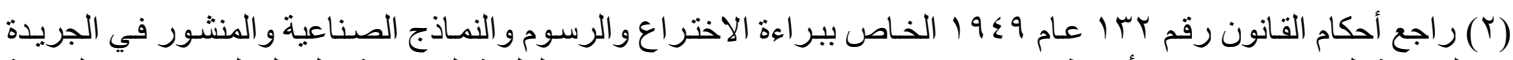

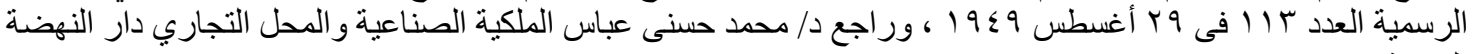

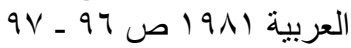

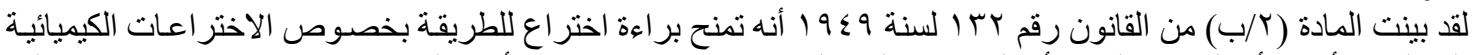

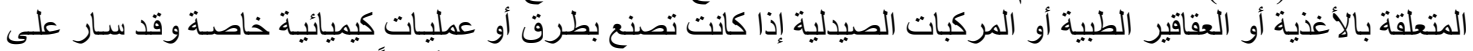

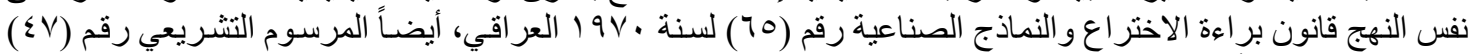

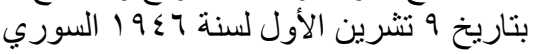


رفض الطلبات المقدمة والتي تحوى في مضمونها طلب تسجيل اختراعات للسـلالات الحيوانيـة (البكتيريـا، الفيروس، الفطر ، اللقاحسات، الأمصـال) وطرق تحضـيرها أو استخدامها في منتجـات أخرى على أسـاس الكثف عن الاختراع يكون بوصفه كتابة. أما إذا تعلق الاختراع بأحد الكائنات الدقيقة أو باستعمالها وكان في إمكان الجمهور التوصل إليها فإن

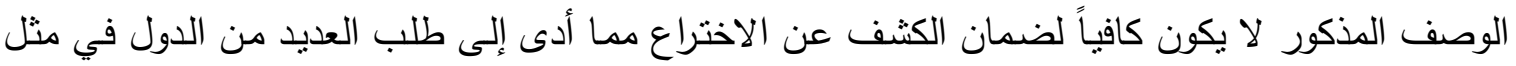

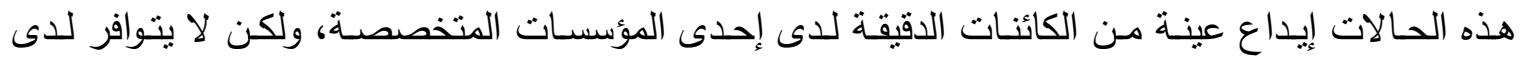
المكتب التجهيزات لتداول الكائنات الدقيقة التي يتطلب حفظها وتسليم عينات منها خبرة تقنية وأجهزة خاصة،

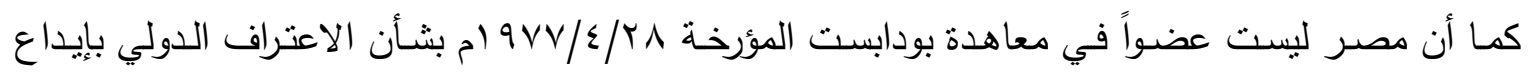
الكائنات الدقيقة لأغراض الإجراءات الخاصة بالبراءات لعدم توافر الظروف المهيأة لذلك من معامل ووسائل حفظ، كما أن هذه النوعية من الاختراعات تصادف تزايداً مستمراً لأنها تمثل تكنولوجيا العصر .

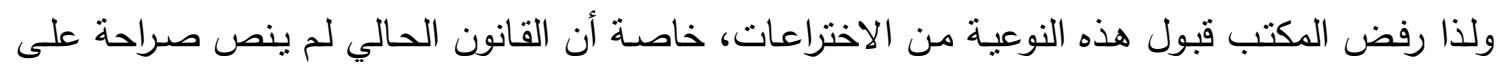
هذه النوعيـة من الاختراعات ولم ينـوه عنها، وقد تم الطلب لمعرفـة مدى قانونيـة تسجيل طلبـات البراءات

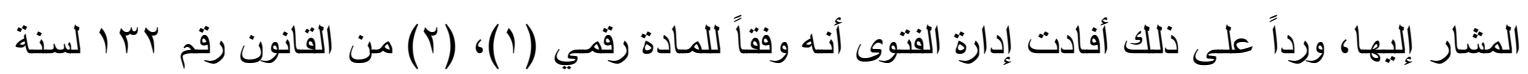
9 § 9 ام قد أناط بالمشرع منح براءة اختراع لكل ابتكار جديد شريطة أن يكون قابلاً للاستغلال الصناعي، سواء كان متعلقاً بمنتجات صناعية أم بطرق أو وسائل صناعية أم بتطبيق جديد لطرق أو وسائل صناعية

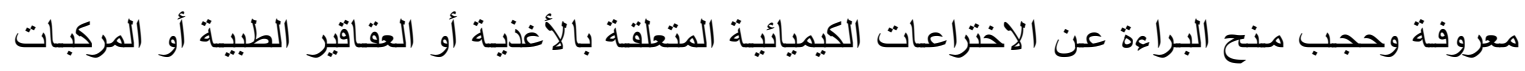
الصيدلية، مع جواز منحها عن طريق صنعها إذا كانت تصنع بطرق أو عمليات كيميائية خاصة، و و حيث الثيل إن الطلبات المقدمة بطلب الحماية القانونية لتسجيل السلالات أو البكتيريا أو الفيروس أو الفطر أو اللقاحات أو الأمصال لا تدخل ضمن الابتكارات القابلة للاستخلال الصناعي، وإنما تدخل في الاختراعات الكيميائية

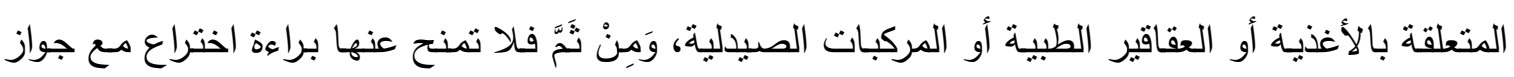
منح البراءة عن طريق تحضيرها إذا كانت تصنع بطرق أو عمليات كيميائية خاصـة وفى هذه الحالة الأخيرة

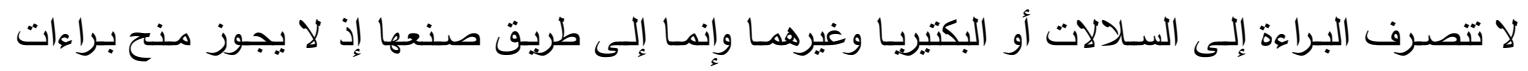

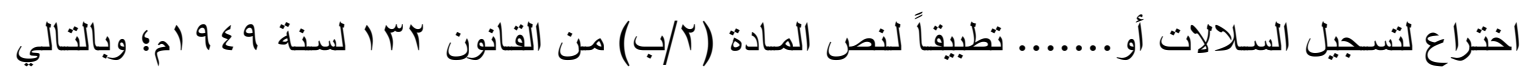

يتم منح البراءة للطريقة فقط وليس منح البراءة للكائنات الدقيقة ذاتها (1).

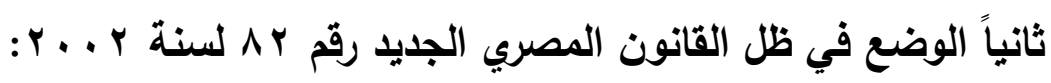
بعد انضمام مصر إلى اتفاقية منظمة التجارة العالمية والاتفاقيات التي تضمنتها الوثيقة الختامية المتضمنة

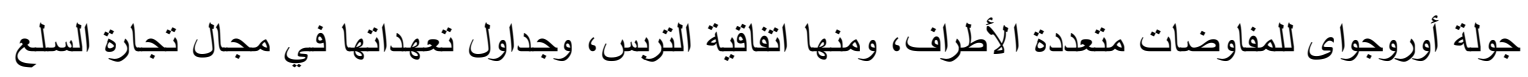

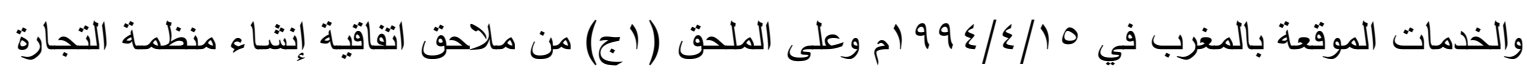

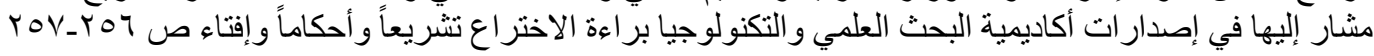


د/ عبدالرحيم عنتر عبدالرحن - د/ محد محمد عبيد مبارك

العالمية، ؛ قد الزمت اتفاقية التيبس الدول الأعضاء بمنح حماية للكائنات الدقيقة كما أوضحنا بنص المادة

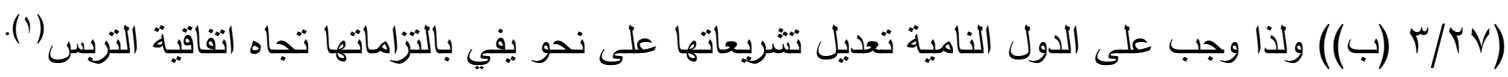

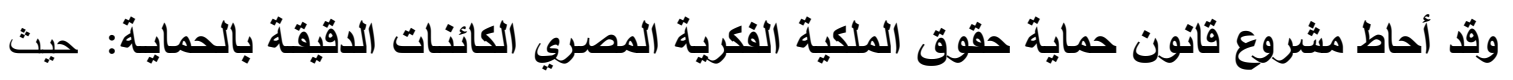
ظهر ذلك من نص المـادة رقم (1) ،"تمنح براءة اختراع طبقاً لأحكام هذا القانون عن كل اختراع قابل

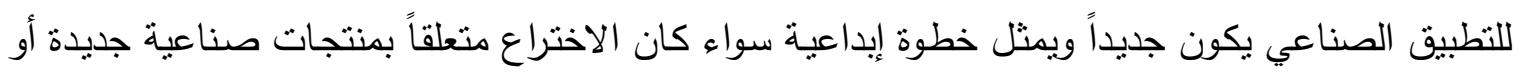
بطرق أو وسائل صناعية مستحدثة أو بتطبيق جديد لطرق أو وسائل صناعية معروفة" . ويثــل مفهـوم الصــاعة في هـا الثـأن المنتجـات الكيميائيـة المتعلقـة بالأغذيـة والمنتجـات الكيميائيـة

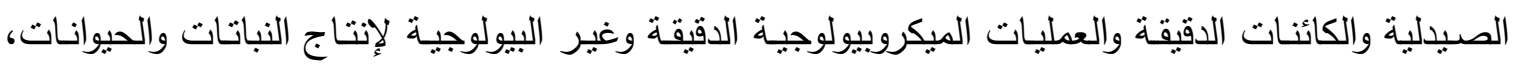
والعمليات البيولوجيـة لإنتاج النباتات ولكن تم تعديل هذه المـادة على نحو أفضل في الصياغة النهائية، وظهر ذلك من المادة رقمي (1) ، (Y) من أحكام قانون حماية حقوق الملكية الفكرية في صورته النهائية على النحو التالي: مادة رقم ( ) "تمنح براءة اختراع طبقاً لأحكام هذا القانون عن كل اختراع قابل للنطبيق

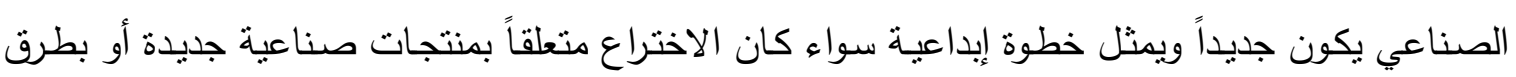

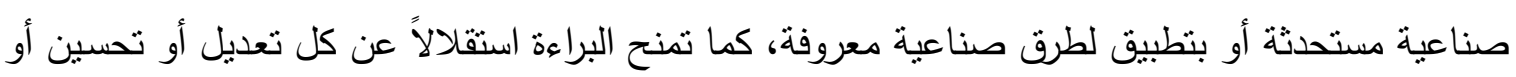
إضـافة ترد على اختراع سبق أن منحت عنه براءة إذا توافرت فيه شروط الجدة والخطوة الإبداعية والقابلية للتطبيق الصناعي على النحو المبين في الفقرة السابقة ....الخ".

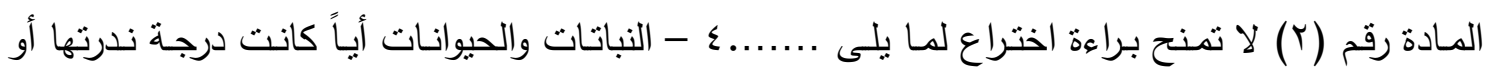
غرابتها وكذلك الطرق التي تكون في أساسـها بيولوجيـة لإنتاج النباتات أو الحيوانات؛ عدا الكائنات الدقيقة

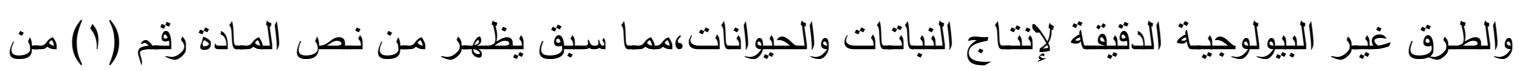

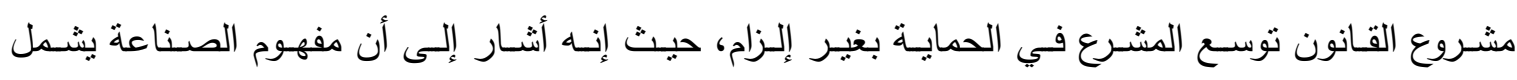

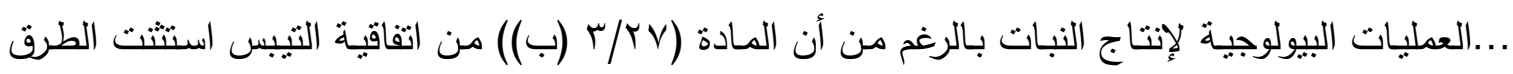

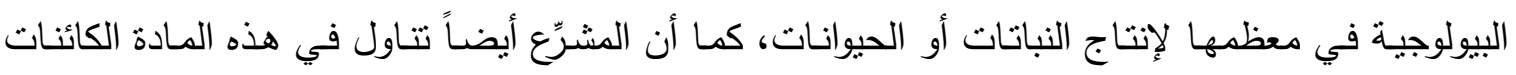
الدقيقة باعنبارها مفهوماً صناعياً. 
ويـرى الباحثان: أن هذا غير دقيق، حيث إن الكائنات الدقيقة تعد كائنات حيـة وقد تكون موجودة في الطبيعة، وليس للإنسان دخل فيها، ولكن تم تلافى ذلك في الصياغة النهائية كما وضـح من نص المـادة

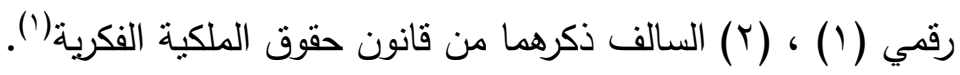

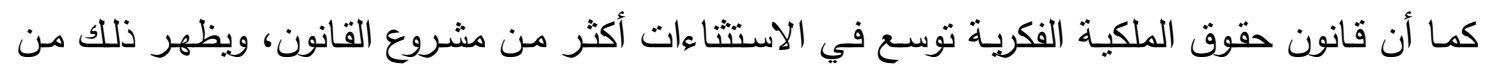

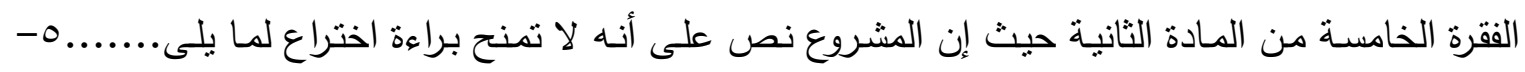

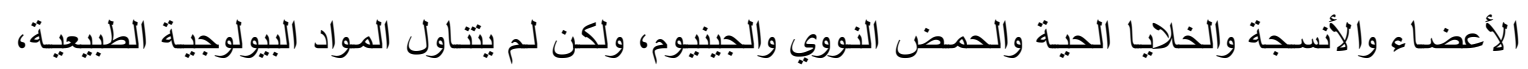
ولكن القانون في صياغته النهائية تلافى ذلك حيث نص على استثناء المواد البيولوجية الطبيعية. ولنا تعليق على نص المادة (ع ا ) من مشروع القانون والمادة (ب I ) من قانون الملكية الفكرية: حيث إن هاتين المادتين تحملان نفس الصيغة بخصوص الكائنات الدقيقة على النحو التالي:" يرفق بطلب

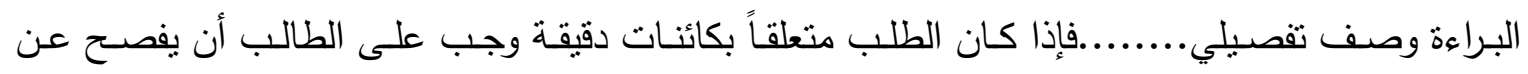
الكائنات الدقيقة وأن يودع مزرعة حية منها لدى الجهة التي تحددها اللائحة التتفيذية". وهنـا كـان يجب على المشرِّع أن يصيخ المـادة على النحو التالي: " إذا كان الطلب متعلقاً

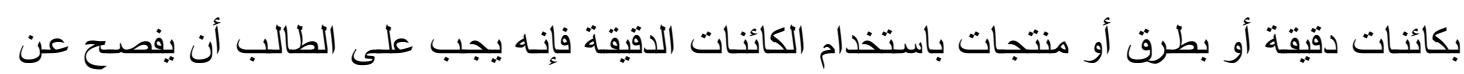
الكائنات الدقيقة وأن يودع مزرعة حية منها لدى الجهة التي تحددها اللائحة التتفيذية(؟). وقد أوضحت المادة الثالثة من اللائحة التفيذية ذلك في الفقرة (ع) منها، حيث نصت على على أنه إذا كان

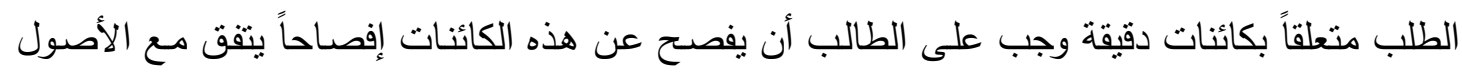

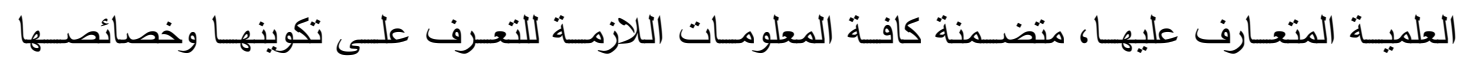
واستخدامها، وأن يـودع مزرعـة حيـة منهـا في أحـد المعامـل التي يصـدر باعتمادهـا قرار مـن الـوزير المختص بشئون البحث العلمي وأن يقدم شهادة تثبت حصول مران الإيداع. وقد صدرت براءة اختراع في مصر: متعلقة بكائن دقيق (وهى خاصة بمبيد بيولوجي) وهذه البراءة عبارة عن مبيد بيولوجي للحشرات، له القدرة على القضاء على أفراد الحشرات التابعة لثناث رتب هي: حرشفيات الأجنحة وغمديه الأجنحة وثنائية الأجنحة، حيث إنه في الآونة الأخيرة تزايد الاتجاه للحد من لن

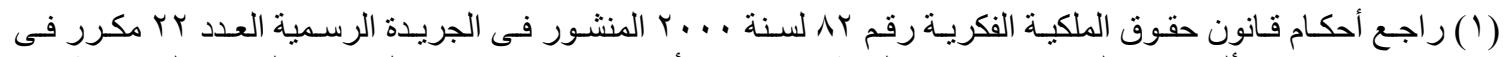

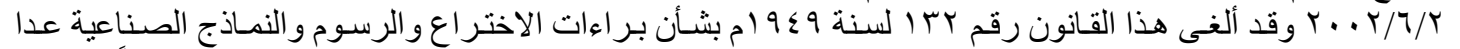

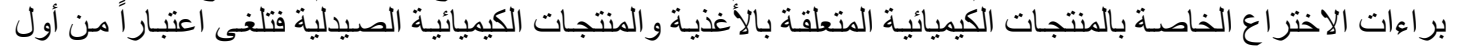

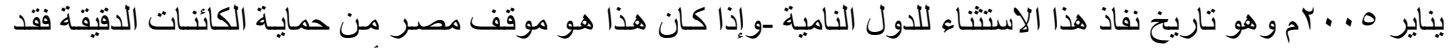

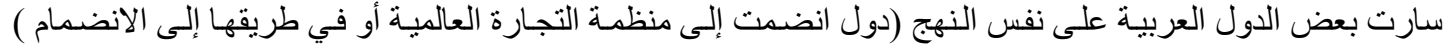

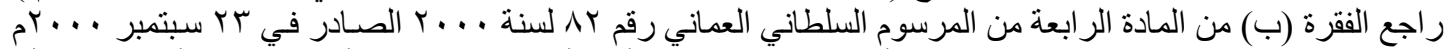

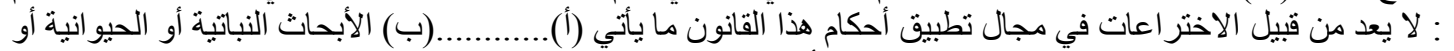

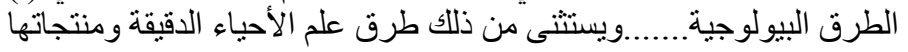

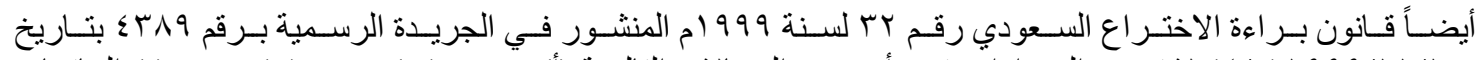

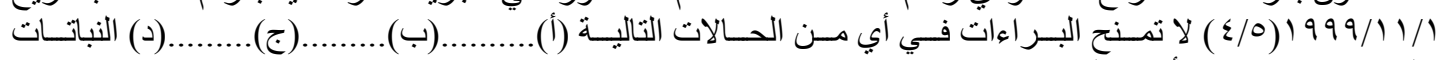

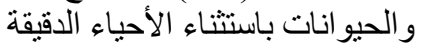

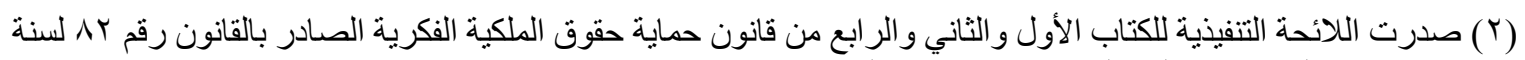

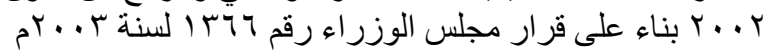


استخدام المبيدات الكيميائية للقضاء على الآفات الزراعية أو الطبية على السواء وذلك لما تسببه هذه

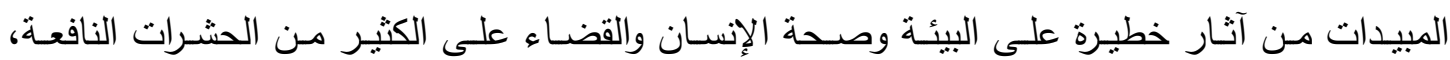
والأخطر من ذلك تمكنت الكثير من الحشرات الزراعية مقاومة معظم هذه المبيدات الكيماوية؛ لذلك تمت من إعادة اكتشاف بكتيريا باسيللى ثثيرنجنسييس (Bacillus Thuringiensis (BT) لاستخدامها كمبيد بيولوجي بديل للقضاء على الحشرات الزراعية والطبية المختلفة التابعة لرتبة حرشفيات الأجنحة وثثائية الأجنحـة وغمديـه الأجنحـة بالإضـافة إلى كونها مبيداً صديقاً وتم استخدامه أول مـرة في أمريكا عـام 90V أما المبيد محل البراءة عبارة عن بكتيريا عضوية الثكل وموجبة لصبغة جرام ولها القدرة على تكوين جراثيم داخلية وأثتاء تكوين الجراثيم تتتج البكتيريا بللورات بروتينيـة قادرة على قتل الحشرات المختلفة نتيجة لسميتها العالية، حيث يبدأ نأثنر البرونين السام في المعي المتوسط للحشرات، حيث وجد أنه تحت تأثثر الوسط القلوي العالي في المعي المتوسط يذوب هذا البورتين البلوري، وتحت نأثير بعض الإنزيمات

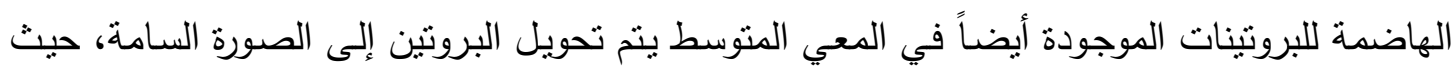
يبدأ هذا الجزء السام في الارتباط ببعض المستقبلات الخاصة الموجودة في المعي المتوسط، ونتيجة لهذا الارتباط يبدأ حدوث اختلال في مرور الأيونات والمواد الغذائية من المعي المتوسط إلى الدم، والعكس

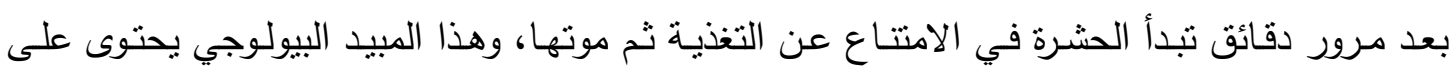

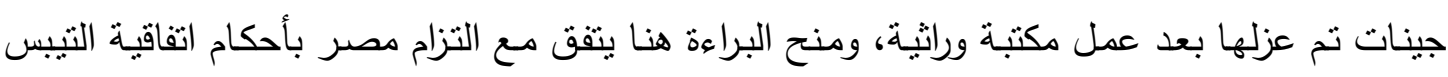

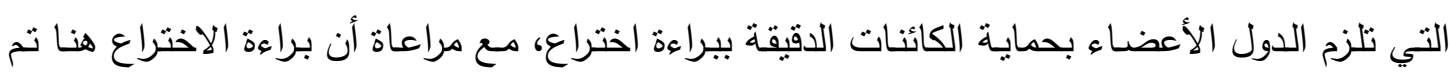
منحها إلى نوع جديد من البكتيريا تم استتباطها بفعل الإنسان (المخترع) وليس مجرد اكتشاف موجود في لئرة

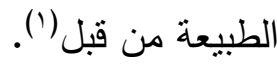

\section{ولكن رغم ذلتك يتم التسـاؤل هل هذه البراءة صدرت على نحو يتوافق مـع القانون أم هذه البراءة}

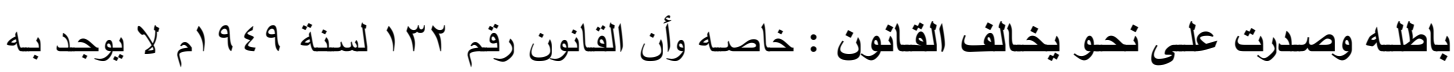

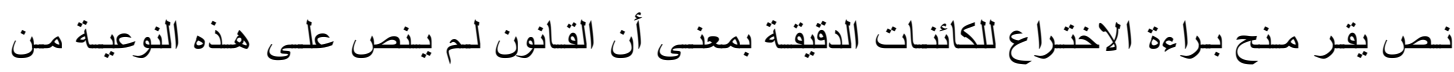

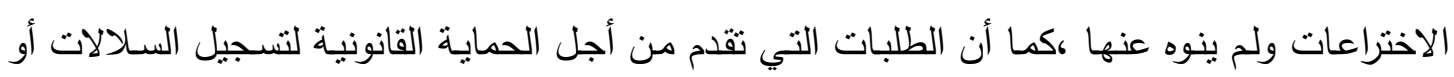
البكتريا، الفيروس، الفطر، اللقاحات، والأمصال لا تدخل ضمن الابتكارات القابلة للاستغلال الصناعي

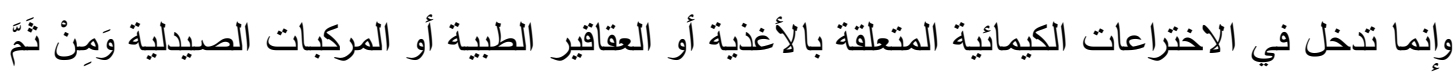
فلا تمنح عنها براءة اختراع مع جواز منح البراءة عن طرق تحضيرها إذا كانت تصنع بطرق أو عمليات

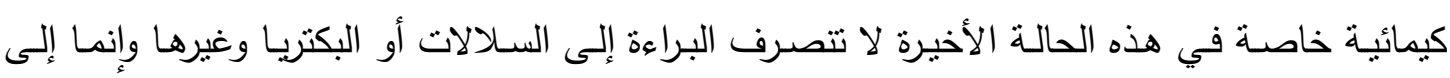
طريقة صنعها، ولكن هذه البراءة تم منحها للمبيد البيولوجي وليس لطريقة صنعة أيضاً في نفس وقت لته صدور البراءة كان لمصر مهله من الوقت لا تلتزم بنطبيق أحكام اتفاقية التربس خلالها ، ومن ثم هن هل 
هذه البراءة صحيحه من الناحيـة القانونيـة بـل الاكثثر من ذلك قانون الملكيـة الفكريـة المصري لم يكن

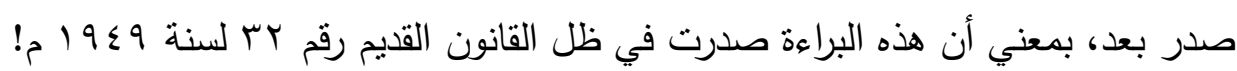

\section{القرع الثالث}

\section{السياسة واجبة الاتباع}

من جماع ما سبق نجد أن: الدول المتقدمة تسعي إلي العمل علي إثباع. المصلحة الذاتية النابعة من رغبة الشركات الكبرى المسيطرة علي مجال حقوق الملكية الفكرية، والتي تصب في النهاية في إناء المصلحة العامة للدولة، حيث إن الكائنات الدقيقة أصبحت لها قيمة علئة عالية في مجال الصناعة الحديثة سواء في المجالات الطبيـة أو الزراعيـة أو الغذائية؛ لذا سعت الدول المنقدمـة إلي منح تفسير لمفهوم

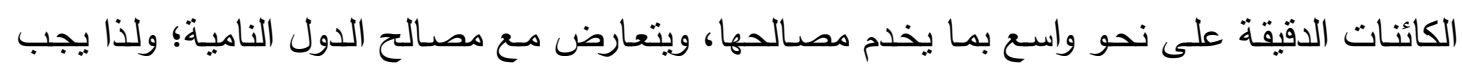

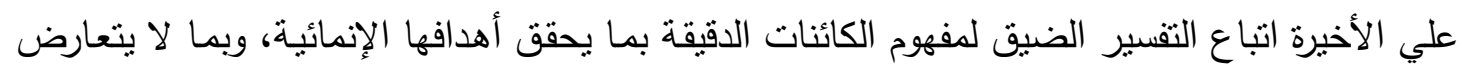

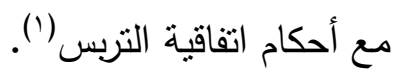

\section{والسياسـة واجبـة الاتبـاع قد تكـون مرتبطـة بتعريـف الكائنـات الدقيقـة ذاتهـا، أو تكون مرتبطـة} بالنواحي الإجرائية الخاصـة بطلب الحصول علي براءة اختراع للكائنـات الاقيقة، ويمكن إجمال هذه السياسة في النقاط التالية:

1- يجب عدم التوسع في تعريف الكائنات الدقيقة وقصره علي التعريف العلمي، (r) أو قصر الحمايـة علي الكائنات الدقيقة التي يتم استتباطها بفعل المخترع مثل الكائنات المبتكرة عن طريق الهندسـة الورانية وعدم منح براءة الاختراع للكائنات الدقيقة الموجودة في الطبيعة أو أجزائها أو عناصرها،

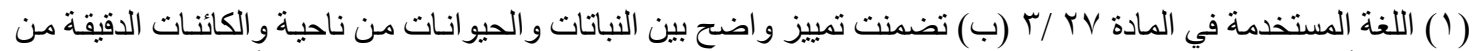

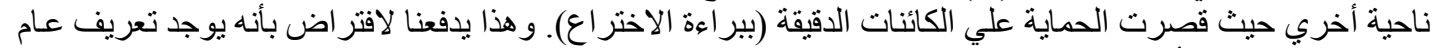

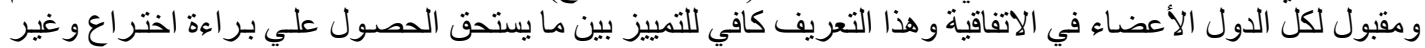

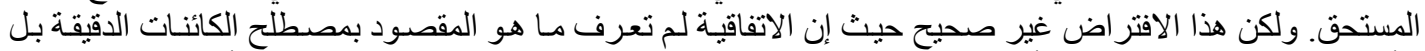

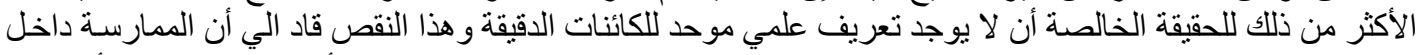

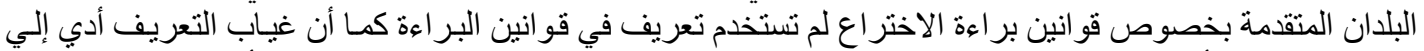

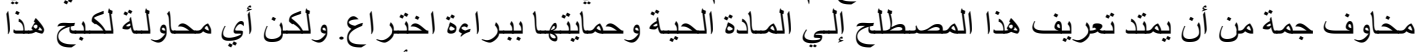

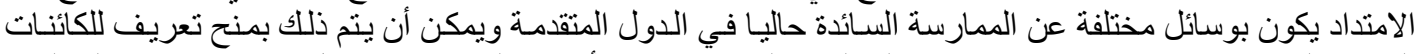

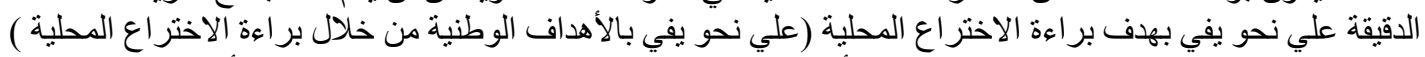

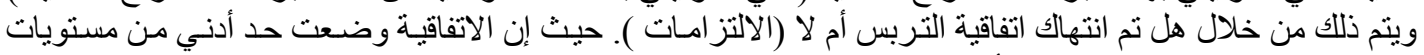

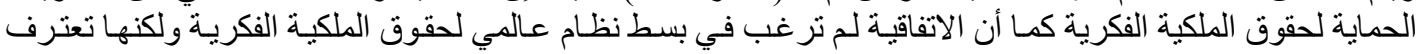

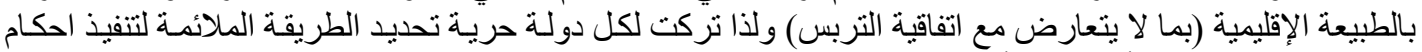
اتفاقية التربس في اطار أنظمتهاو أسألييها القانونية راجع التربع

Dr. Mike Adcock and Dr. Margaret Lewelyn.op.cit.pp. ${ }^{r},\ulcorner$

( $\ulcorner$ ) Coombs,J.Mac millan Dictionary.op.cit.p. 191 
حيث إن هذا يمثل اكتشافاً وليس اختراعاً (1). وبالتالي يمكن القول بأن مصطلح الكائنات الدقيقة يعنى الكائنات التي أقل من الميكرون وتتضمن البكتيريا، Mycoplasma، والخمـائر والطحالب وحيدة الخلية، Protozoa، وهي لا تتضمن الكائنات

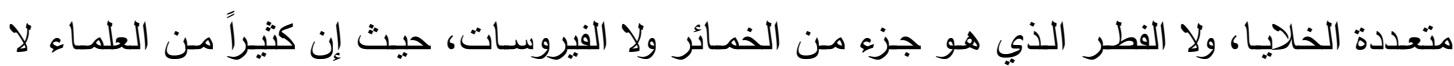
يضفونهم ككائنات دقيقة؛ وبالتالي يمكن تنبى هذا التعريف العلمي من قبل الدول النامية، أو التعريف

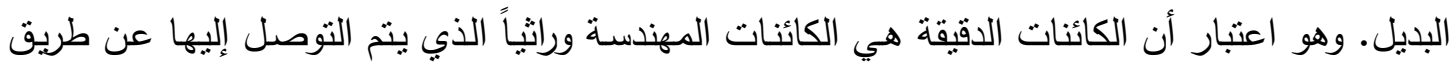
التدخل البشري في التوليف الوراثي سواء بالهندسـة الوراثية أو بتقنية أخري مـع استثناء كافة الحيوانات والنباتات أو أجزائها(ب)

r - يجب الفحص الفني الدقيق للكائنات الدقيقة المراد منحها براءة اختراع للتيقن من توافر الثروط التقلبدية للحصـول علي براءة اختراع وهى: الجدة:Novelty. حيث يمكن أن ينظر إلي هذا الثـرط علي أن الاختراعـات التي تتضـمن مـادة بيولوجيـة سـوف تكون غير جديرة بالجدة إذا كانت المعلومـات عنها أصبحت في الملك العامPublic Domain أوإذا كان الاختراع مجرد نسخ للمادة البيولوجية، أو عبارة عن بيان لوظيفة المادة البيولوجية التي تحدث طبيعياً.

كما أن أي معلومات أو نشر عن الكائنات الدقيقة قبل المطالبة بمنحها براءة اختراع يتعارض مـع الجدة،

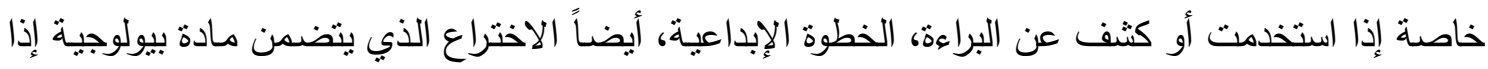
بنـي علي مجرد تحديد هويـة المـادة البيولوجيـة أو وظيفتها هذا لا يمثل خطوة إبداعيـة؛ ولكن تعد الخطوة الإبداعية منوفرة إذا كان للتطبيق أهمية تقنية كبيرة ، وبالتالي التطبيق الفني يجب أن يمثل تقدماً تقنياً كبيراً في الفن المسبق، كما أن التطبيق الصناعي يتوافر اذا كان الاختراع الذي يتضدمن مادة بيولوجية جديراً بالتطبيق الصناعي بمعنى إذا كان واضحاً أنه أسلوب جديد في النطبيق ويمنح منفعة عامة يمكن إثباتها، والمنفعـة العامـة تعنـي أن الاختراع يجب أن يكسون قـابلاً كأسـلوب ليقود إلـي الصـحة العامـة والرفاهيـة الاقتصادية والاجتماعية(r).

( ) Dr. Mike Adcock and Dr. Margaret ilewelyn Sheffield institute for Biotechnology law and ethics university of Sheffield uk. Micro- organisms, Definitions and option under trips an addendum to the paper prepared for the discussion meeting Quaker unGeneva $r$ rrd November $Y_{\ldots} .0$ P. ${ }^{17}$. further in formation see page( ${ }^{7}$ )of the original paper from the definition used by the institute of science, uk

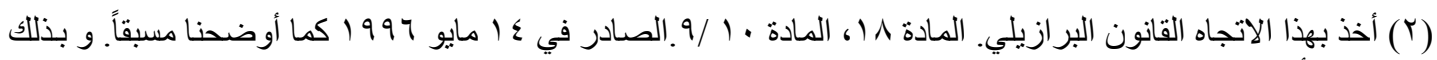

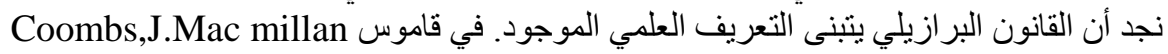

( $($ ) Dr.Mike Adcock and Dr. Margaret ilewelyn op-cit p. IV

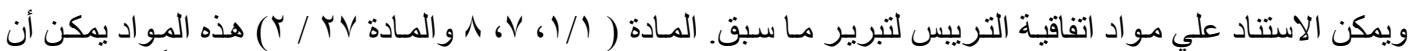

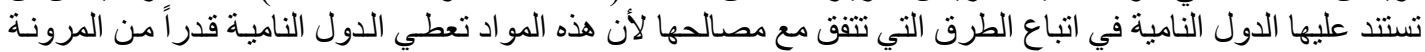


ب- استبعاد الاختراعات المرتبطة بالكائنات الدقيقة التي تضر بالنظام العام أو الأخلاق أو الحياة أو الصحة

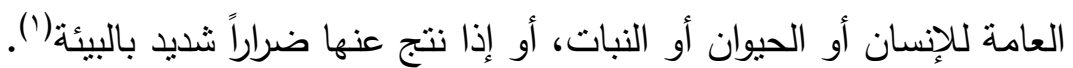

ع - يجب إعمال معايير السلامة والأمن البيولوجي بخصوص الكائنات المحورة وراثياً حتي نتلافى مخاطرها التي قد تظهر فيما بعد كما حدث بخصوص المبيدات الزراعية(؟).

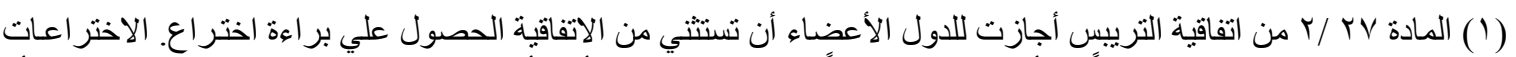

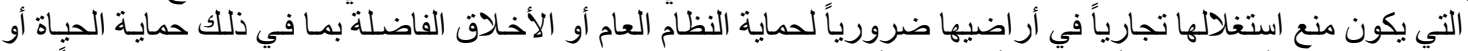

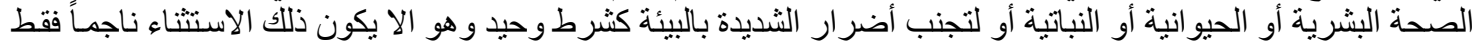

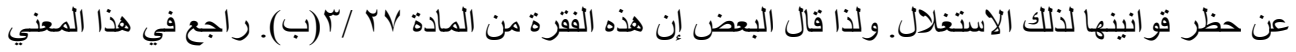

DR.Mike Adcock and DR.Margaret Llewelyn op.cit.p. r •

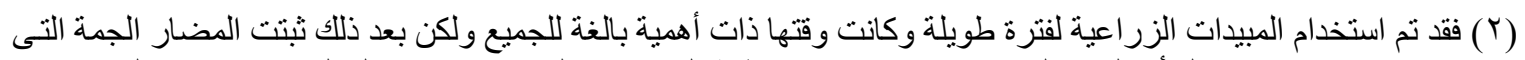

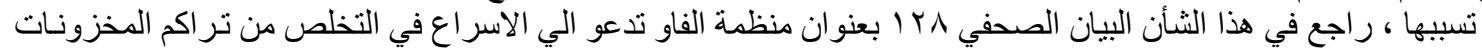

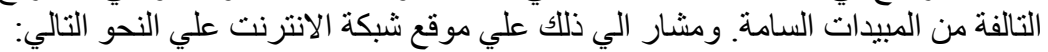
http://www. ' .fao.org/ar-ep/press/pressing/r..1/pr. 1 r^.htm

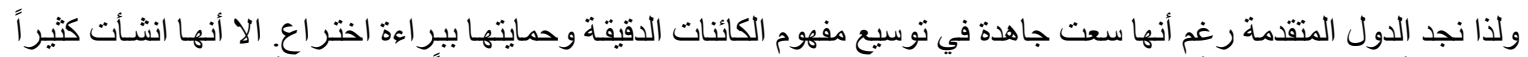

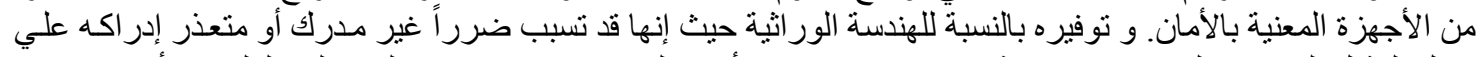

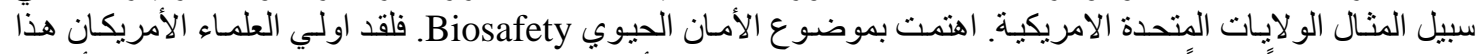

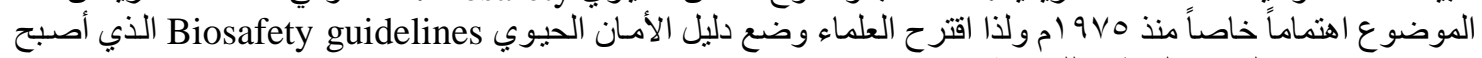

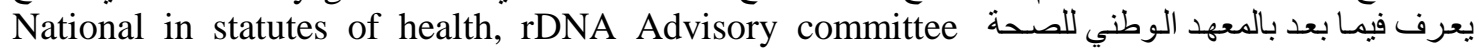
(NIHRAS)

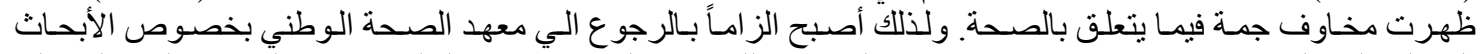

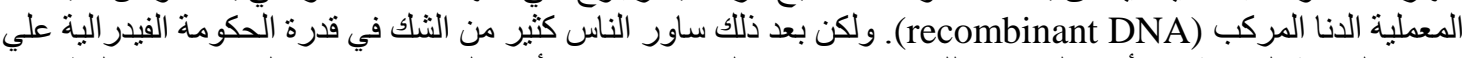

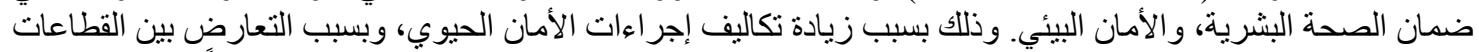

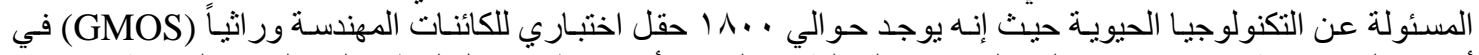

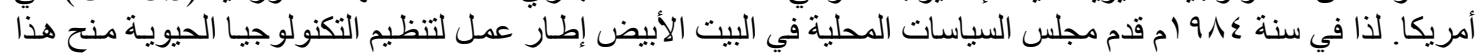

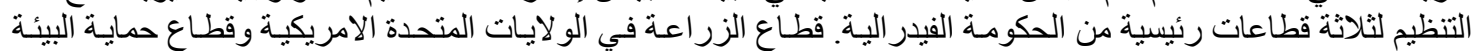

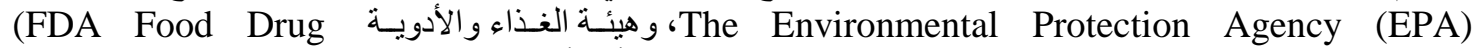

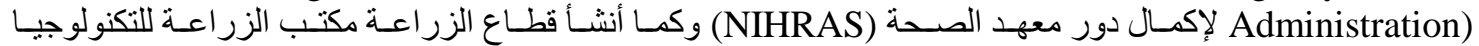
الحيوية Office of Agricultural Biotechnology (OAB في عام 914 ام. ثم تم إنشـاء لجنة المشورة للأبحاث الزر اعية) Agricultural Biotechnology Research Advisory committee (ABRAS) ويعمل بها فيا خبر اء من

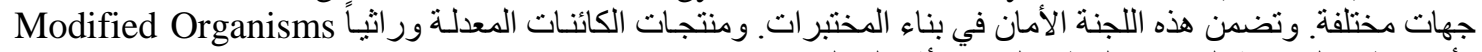
و أنشا قطاع الزر اعة البرنامج الوطني لتقييم الأثر البيولوجي National Biological United States Department of Agriculture (USDA) Impact Assessment Program (NBIAP)

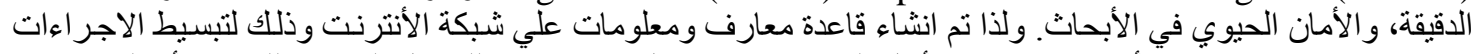

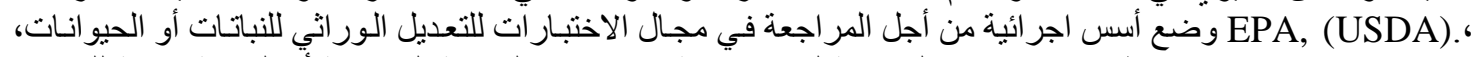

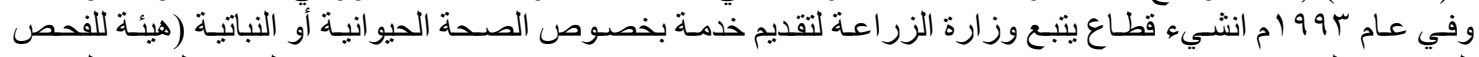

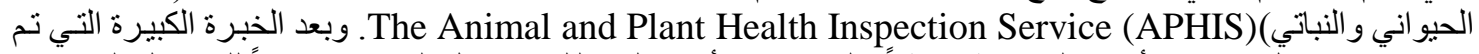

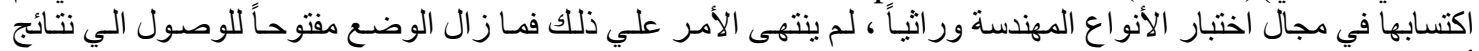

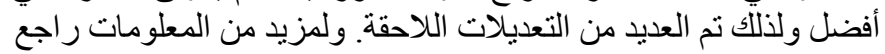

L.J.Butelr.The regulation of agricultural biotechnology in the USA ( 1990 Biotechnology and development monitor no. $r \varepsilon, p . r \tau$.

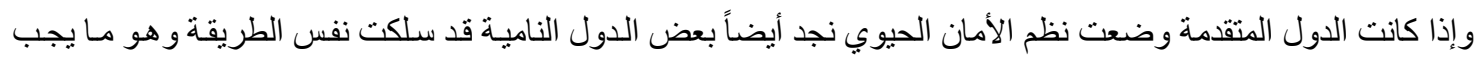

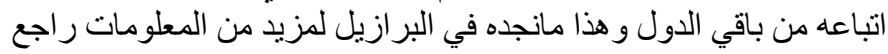

Bernardo Eliasc soares, thomas Gilbert B.Howe, Leila Macedo oda, Fundacáo oswaldo cruz, cictDepartment de Estudios em cien ciae Techndogia, riode Jameiro, Brazil university of Bristol, department of pathology school of medical sciences Bristol UK.Library: Binas News: vol. ${ }^{r}$, issues $r \& \varepsilon, 1997$.

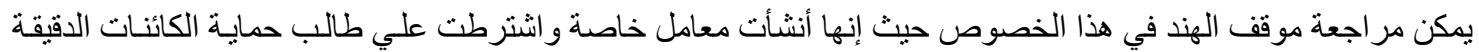

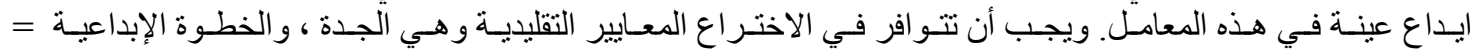


ه - يجب على طالب الحماية للكائنات الدقيقة أن يفصح عن هذه الكائنات إفصاحاً تاماً يتفق مع الأصول

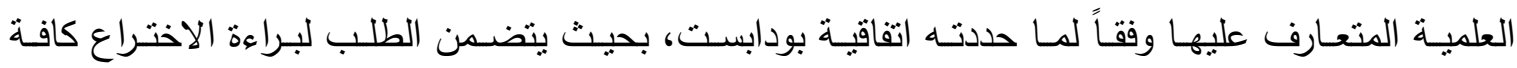
المعلومات اللازمة للتعرف على تكوينها وخصائصها، ونفس الأمر إذا كان الطلب لبراءة الاختراع مرتبطاً بطرق أو منتجات باستخدام الكائنات الدقيقة، وهذه المعلومات يجب أن تتاح للعامة.

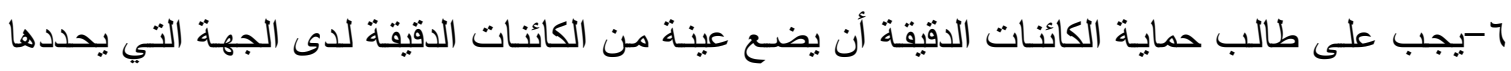
القانون الوطني أو اللائحة التنفيذية.

= و القابلة للاستغلال الصناعي ، وقد طلبت بعض البلدان أن لاتكون الكائنات الدقيقة قد وصفت في الآدب، و البعض الأخر الكابر

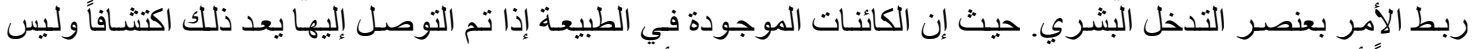

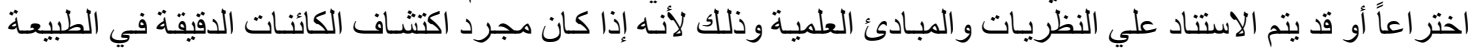

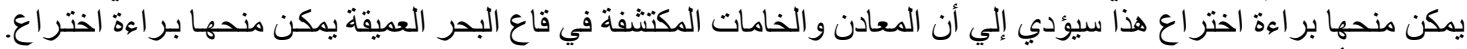
وما يمكن أن يمثله ذللك من مخاطر جمة علي الدول الدئ النامية.

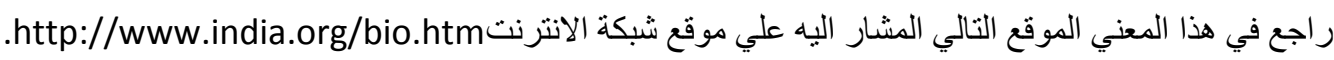

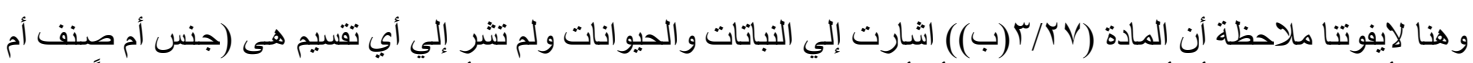

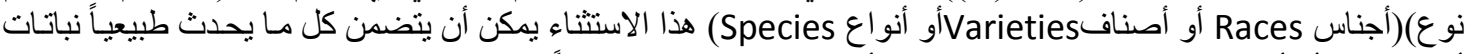

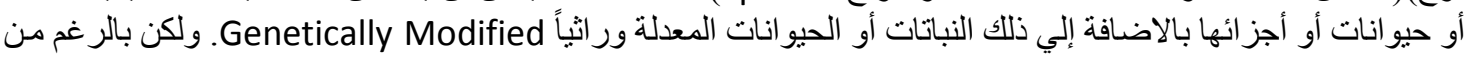

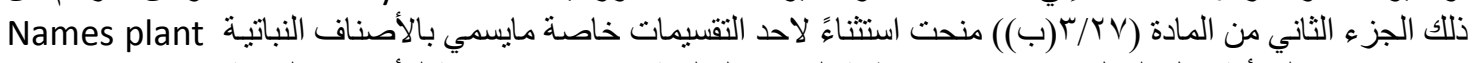
varieties

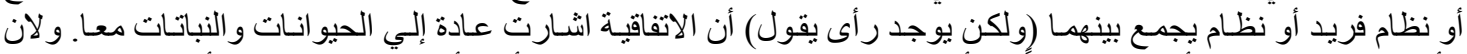

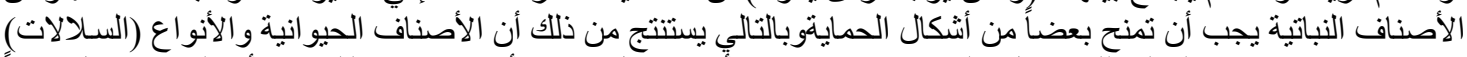

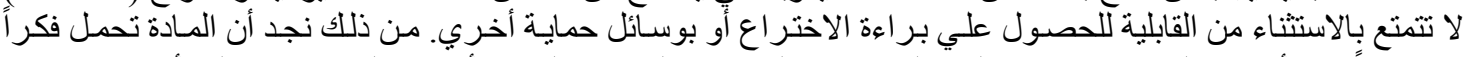

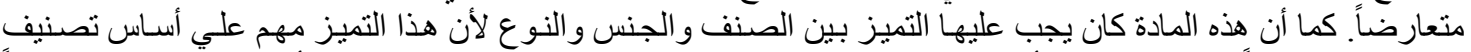

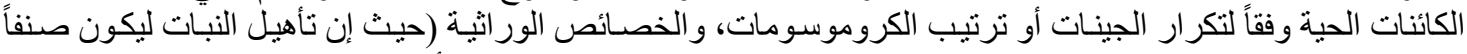

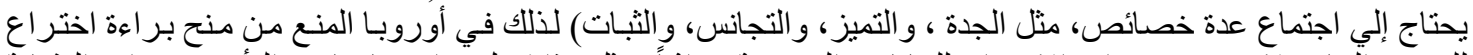

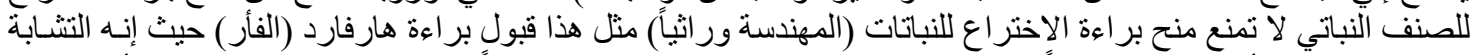

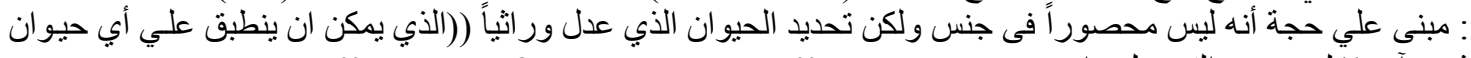

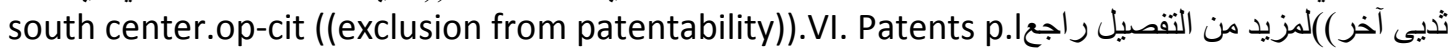




\section{الخاتمة}

الحمد لله الذي بنعمته تتم الصالحات، ونتابع النعمات، نحمده و ونشكره على توفيقه وإعانتتا لنا على إتمام هذا البحث، ونسأله المزيد من فضله وإنعامه، ونصلى ونسلم على خير الخلق نبينا محمد وعلى آلة وصحبه أجمعين، ومن اتبع هداه إلى يوم الدين.

\section{أما بعد ،6،}

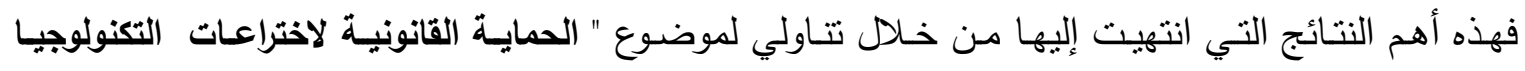
الحيوية":

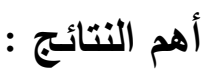
1. تباينت الحماية القانونية للتكنولوجيا الحيوية وذلك باختلاف الانظمة والتشريعات التي قررت لها هذه الحماية ، حيث أن بعض من هذه الحماية مقرر باتفاقيات دولية تم التوقيع عليها من قبل الامم المتحدة مثل ( اتفاقيه التربس) ، والبعض الاخر جاء في القوانين والتشريعات الوطنية الخاصة بالدول والتي قررت حماية التكنولوجيا الحيوية. r. لم تستقر التشريعات والقوانين التي نظمت الحماية القانونية للكائنات الدقيقة على تعريف قانونى محدد لها ، ويرجع السبب في ذلك إلى أن أتفاقيه التربس لم تعرف المقصود بالكائنات الدقيقة الواجبة الحماية بموجب هذه الاتفاقية ، وهو الذى أدى بدورة إلى عدم وجود إجماع بخصوص مايعتيه مصطلح الكائنات الدقيقة في المجتمعات العلمية . r. أوردت الدول المتقدمة النص في تشريعاتها على تقرير الحماية القانونية للكائنات الدقيقة بموجب براءات اختراع وذلك وفقاً لما ورد النص علية في اتفاقية التربس ، بيد أن الدول النامية كانت بعيدة عن الاتجاه الذي سلكته الدول المثقدمة، حيث إن أغلب نشريعات الدول النامية لا تتضمن أحكاماً تحمى الكائنات الدقيقة بموجب براءة الاختراع، ولكن هذا الموقف لم يستمر خاصة بالنسبة للدول التي حصلت على عضوية منظمة التجارة العالمية، حيث إن اتفاقية التربس تلزم الأعضاء بحماية الكائنات الدقيقة ببراءة

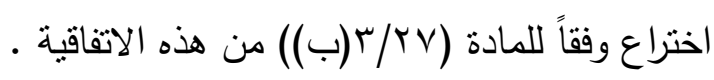
ع. أورد المشرع المصري النص على الحماية القانونية للكائنات الدقيقة التي تصدر براءات اختراع عنها ، وذلك وفقاُ لقانون حماية الملكية الفكرية المصري ، وذلك تطبيقاً لما ورد النص علية في اتفاقية التربس وبعد انضمام مصر إلى منظمة التجارة العالمية والتصديق على الاتفاقيات ذات الصلة بالحماية القانونية لبراءات الاختراع ومنها حماية الكائنات الدقيقة. 


\section{التوصيات والمقترحات :}

1. يجب عدم التوسع في تعريف الكائنات الدقيقة وقصره علي التعريف العلمي فقط، وهو الذى يترتب

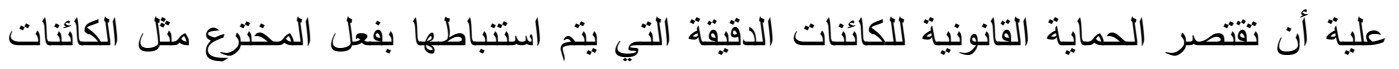

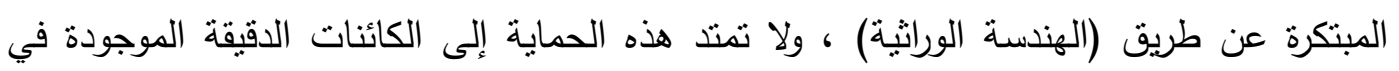

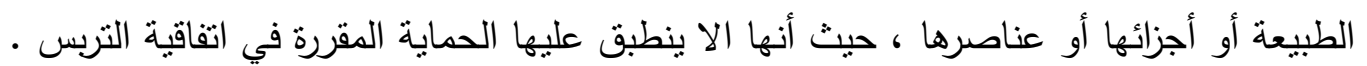

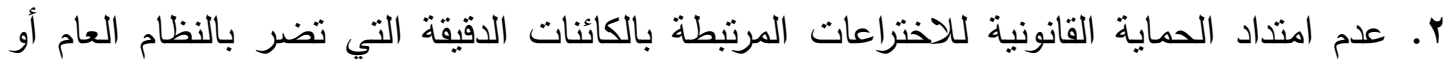

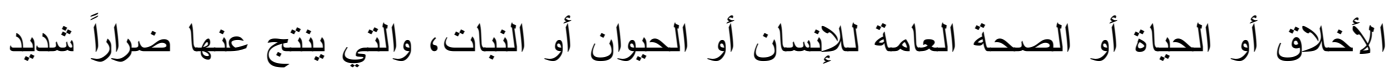

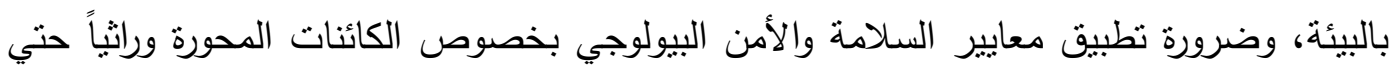
نتلافى مخاطرها التي قد تظهر فيما بعد .

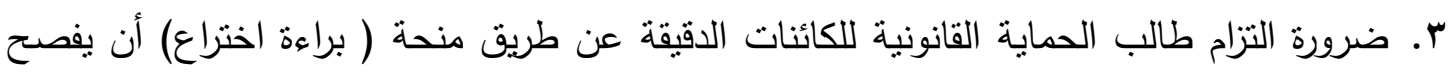

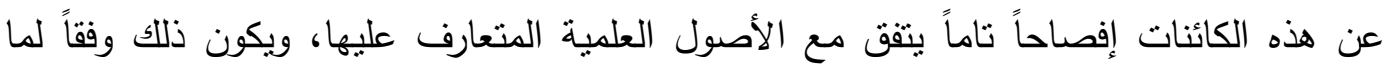

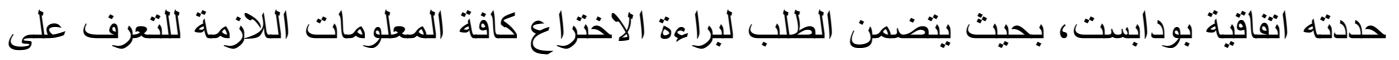

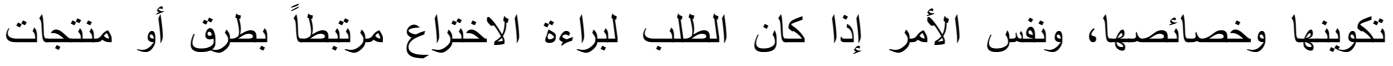
باستخدام الكائنات الدقيقة، وهذه المعلومات يجب أنف الن تلتاح للعامة. 


\section{المراجع والمصادر}

أولاً: المراجع باللغة العربية :

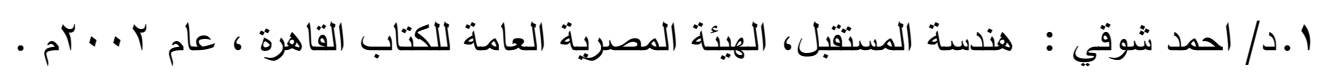

r.د/جودى وانجرجوانز، دجى لى سكليتجنون، د/ ديفيد وانستين، د/ باتريشيادورست : الملكية الفكرية

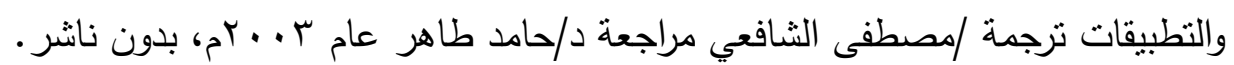

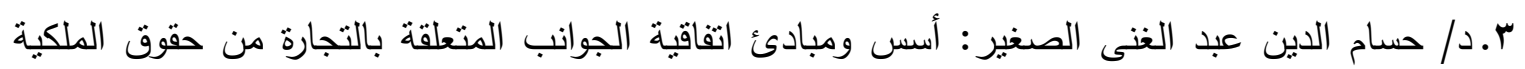

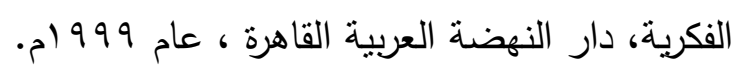

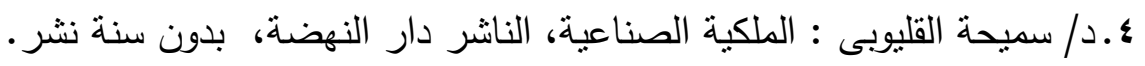

ه.د/ عبدالباسط الجمل: الهندة الوراثية (الألم والأمل) ، الناثر الهيئة المصرية العامة للكتاب، القاهرة ،

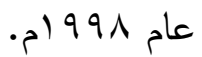

4.د / محمد حافظ عبده الرهوان: اتفاقية التجارة العالمية (الجات)، اهم احكامها وتأثبرها على اقتصاديات

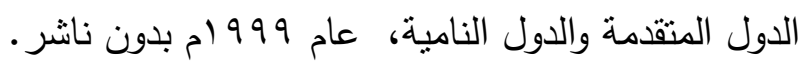

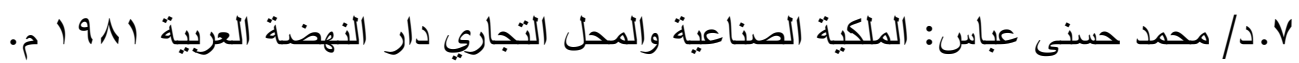

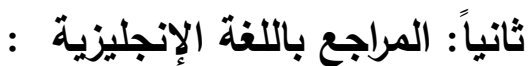

1. Chavanne et Burst droit de la properiété industrielle edition 199. no. 111 .

r. DR.Mike Adcock ,DR.Margaret ILewelyn.Sheffield Institute for biotechnology law and ethics university of Sheffield UK occasional paper $r$ micro-organisms Divinations and option under TRIPS and micro-organisms. Definition and options under TRIPS: friends whorled committee for consultation Quaker United Nations office Geneva Switzerland.

r. Howard Florey / relaxing (1990) European patent office Reports .

๕. Harvard oncompose (199.) O.J.EPO 019, plant Genetic system(Trot/9 $)$ ( 1990$)$ EURPEAN PATENT OFFICE ، Reports Tov, Howard Florey/relaxing ibid.

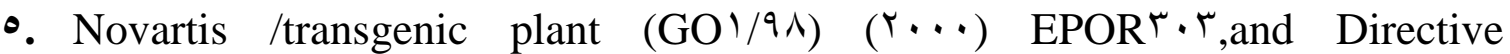
$\mathrm{EC} / \varepsilon \varepsilon / 91$

7. meeting with dated $r \cdot$ jun. $199 \wedge$, prepared jointly by the European patent office the Japanese patent office. And the US patent and trademark office page. ${ }^{\circ}$ of that document .regards (Definition of micro-organism)

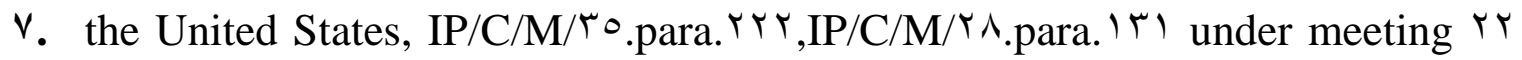
June 1999 until $r$ mar $r \cdots r$ of the work of the trips council

$\wedge$. India, IP/C/M/ $/$. Further information Review of the provision of the article $r V / r$ (b) (communication from India of council TRIPS) $r$ NOV. 1999

१. UNCTAD,THE TRIPS AGREEMENT and developing countries NOW YORKGENEVA UN,Pr 
1. Journal of intellectual property rights vol.^,September $\uparrow \ldots r$ pp. ${ }^{\mu} \circ \vee_{-} r \vee \varepsilon$

11. DR. Mana Ashiya, Harvard medical school center for international development at Harvard university (CID) intellectual property rights in biotechnology.

1 r. DR. William lies.Higher life-forms before the law.the Supreme Court of Canada's recent decision patenting of the (Harvard Mouse) raises issues that go far beyond the laws simple categories of life forms. Available at: http://www.leiss.ca/chronicles/ ${ }^{9} \cdot$ lottawa,onk $n^{7}{ }^{\top}{ }^{\circ}$ canada.htm $^{2}$

1\%. David Gambrill .law times.court allows patent on Harvard mouse Decision paves the way for patenting all life forms except Humans available at: http://www.canadalawbook.ca/headlines/headlines or-arc.htm

1\&. Lanjude and Mathew Frankel. European parliament approves biotech directive, law journal extra Sep. /oct. 1991 .

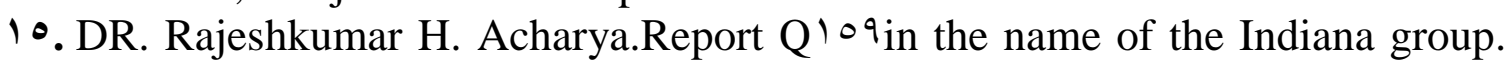
available at:

1 . http://www.aippi.org/reports/q 109 -india-e

$1 \vee$. The patents (amendment) ACT $r \ldots r$ enlarging the scope of patentability to include micro-organisms further information see.unitaksreedhara intellectual property rights in the pharma sector - India initiatives business briefing pharmacy $r \cdots r$, available at : http://www.jacobacci.com

1^. L.J.Butelr.The regulation of agricultural biotechnology in the USA (1990 Biotechnology and development monitor no. $r \leqslant$.

$$
\text { ثالثاً: الابحاث والرسائل والدوريات : }
$$

ا. ألن جالوش تحديات حماية الملكية الفكرية من منظور عربي دولي بحث مقدم إلى ندوة الجمعية الدولية لحماية الملكية الصناعية في الفترة من ابإلى بـ أكتوبر 99 ام ترجمة د/أمل الصبان من الفرنسية

$$
\text { إلى العربية. }
$$

r.د/حسام عبد الغنى الصغير : ورقة عمل قدمت إلى ندوة مستقبل اتفاقية حقوق الملكية الفكرية بمركز بحوث ودراسات التجارة الخارجية عام ا. ..بم بعنوان الاختراعات المستبعدة من الحماية في مشروع قانون الملكية الفكرية.

r.د/عبدالعزيز محمد السويلم: ورقة عمل بعنوان مستقبل التقنية الحيوية ودورها في تطوبر القطاعات الاقتصادية في المملكة العربية السعودية حتى عام • عـ اهـ، ندوة الروية المستقبلية للاقتصاد السعودي

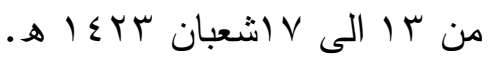

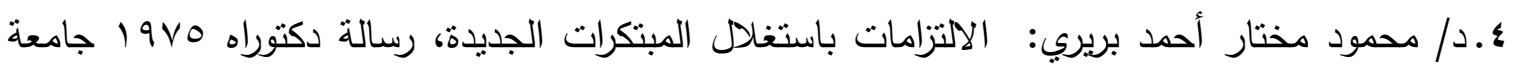

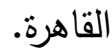

ه.د/ مصطفى عز العرب: ورقة بحثية بعنوان اتفاقية التربس ألبات الحماية وبعض معارضات الدول النامية ، مقدمة الى ندوة مستقبل اتفاقية حقوق الملكية الفكرية في ضوء بعض اتجاهات المعارضة على بلى

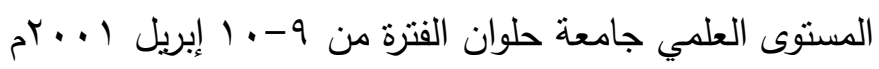


رابعاً: التشريعات والقوانين والمعاهدات :

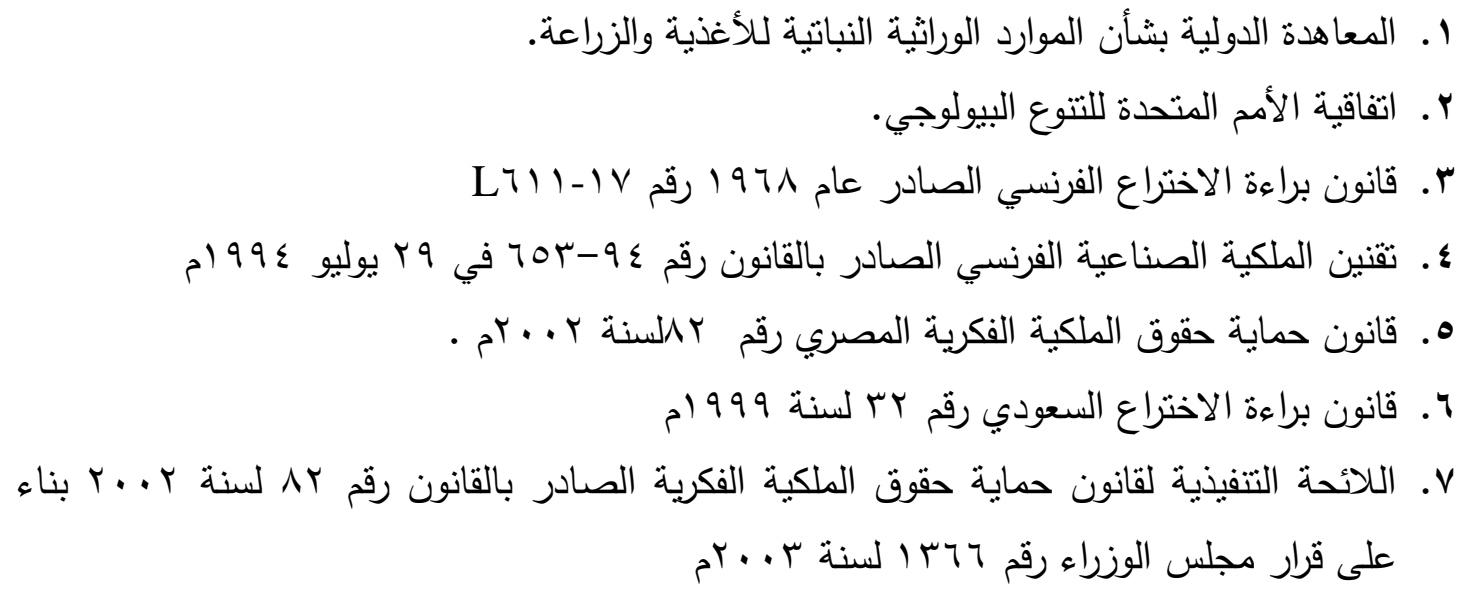

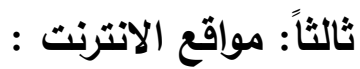

1. http://www.fiqhacademy.org.sa/qrarat/ $\cdot-r$.htm

$r$. -http://www.smsec.com/family/sc $\varepsilon$ all/geeng $\vee$.htm

r. - http://www.werathah.com/learning/papers/concergenetics.doc

₹. - http://www.fao.org/ag/magazine/fao-org.pdf

$\circ$. https://www.cbd.int/history.

7. http://law.uokerbala.edu.iq/index.php/art// Y०-different-articles/00^-dr-adelshemran-artc l

v. http://www.fao.org/nr/cgrfa/cgrfa-global/cgrfa-planttr/ar/

^. http://www.upov.int/en/publications/conventions/ $991 /$ act 1991 .htm

१. //:www.stylecraze.com/articles/heterotrophic-nutrition-and-what-are-its-types

1. .www.diffen.com/difference/Eukaryotic_Cell_vs_Prokaryotic_Cell

1).http://www.wrongdiagnosis.com/medicalymicro-organism.htm

1 r.http://www.fasload.org/mi/micro.organism.htm

ir. gttp://www.idrc.ca/books/Vro/chap $₹ . h t m l$

$1 \leq$. http://www.southcentre.org/info/southbulletin/

10.www.ladas.com/bulletins/ $/ \cdot \cdots \varepsilon / \cdot r \cdot \varepsilon$ bulletin/canda_higherlifeforms.htm

17 .https://supreme.justia.com/cases/federal/us/ $\leqslant \leqslant V / r \cdot r /$ case.html.

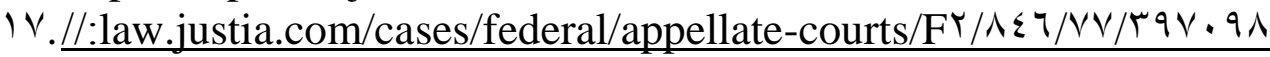

1^.www.inter-lawyer.com/lex-e-script/articles/patent-scope.htm

19 .http://www.cbdn.ca/englisg/discover/patent.html

$r \cdot . \mathrm{com} /$ masrawynews.htm

r). //:WWW.greenpeace.org/comms/q $/$ /geneng/mepo ${ }^{r} \cdot \mathrm{html}$

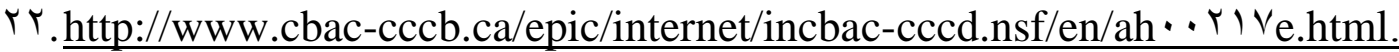

$r \mathrm{r}$./Www.home.earthlink.net/apronto/treaties/intellec.ht

$r \varepsilon$. http://www.india.org/bio.htm. 
د/ عبدالرحيم عنتر عبدالرحمن - د/ محمد محمد عبيد مبارك

\section{الفهربس}

\section{جدول المحتويات}

191

ملخص البحث .

199 المقدمة

* المبحث الاول

$r \cdot 1$ ماهية التكنولوجيا الحيوية والتطور التاريخي للكائنات الدقيقة

$r \cdot 1$ المطلب الاول : ماهية التكنولوجيا الحيويةr. o المطلب الثاني : النطور التاريخي لتعريف الكائنات الدقيقة* المبحث الثاني

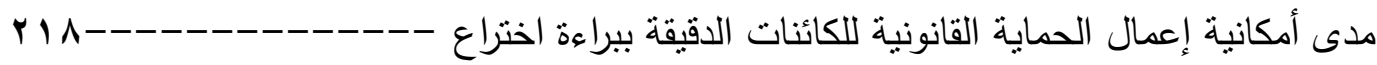

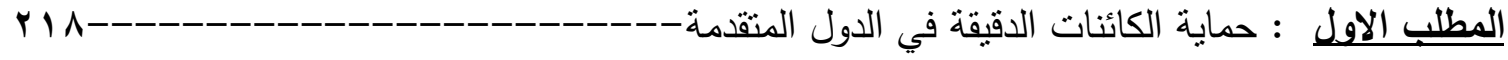

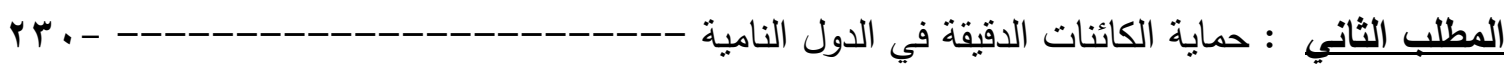

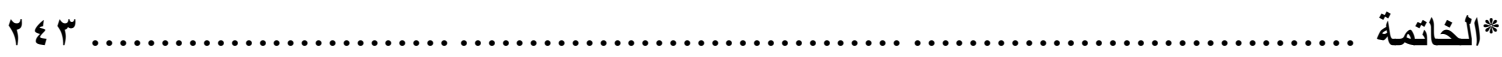
$r \leqslant 0$ * المراجع والمصادر * $r \leq \Lambda$ *)|الفهرس 